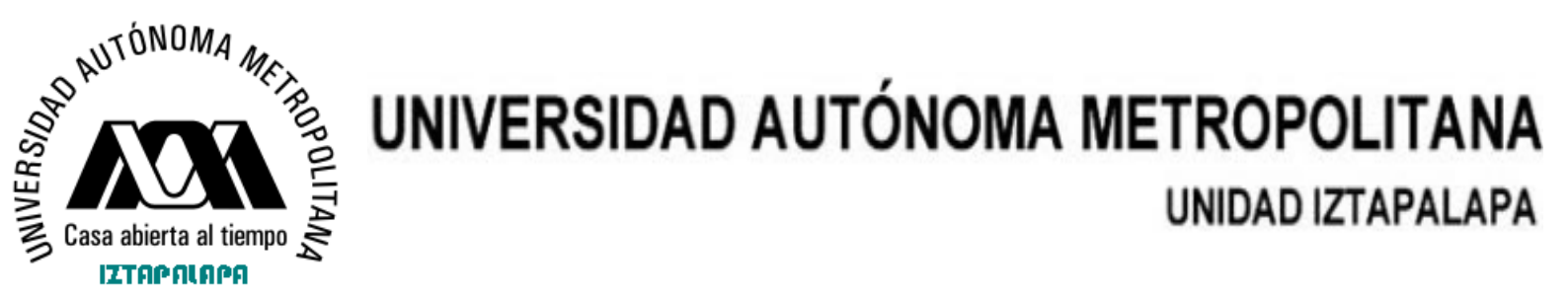

DIVISIÓN DE CIENCIAS SOCIALES Y HUMANIDADES

MAESTRÍA EN ESTUDIOS SOCIALES

LIINEA DE ECONOMÍA SOCIAL

\title{
"EL PAPEL DE LA BANCA COMERCIAL EN MÉXICO, TRAS UN LARGO PROCESO DE DESREGULACIÓN (1980-2009)"
}

IDÓNEA COMUNICACIÓN DE RESULTADOS

QUE PRESENTA

\section{WENDOLYN BRAVO ZURÍTA}

210381086

\begin{abstract}
PARA OPTAR POR EL GRADO DE MAESTRÍA EN ESTUDIOS SOCIALES, LIINEA DE ECONOMÍA SOCIAL.
\end{abstract}

\section{DR. GREGORIO VIDAL DIRECTOR}

DRA. ALICIA GIRÓN JURADO
DR. WESLEY MARSHALL JURADO 


\section{ÍNDICE}

Introducción 3

Capitulo 1. Antecedentes de la crisis de larga duración en México

1.1 El concepto de Modo de regulación ......................................... 8

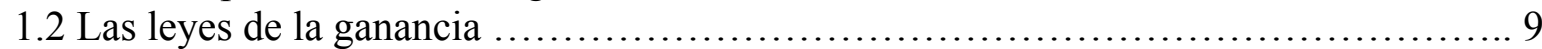

1.3 Fases de la crisis del modo de regulación ..................................... 11

1.3.1 La primera fase de la crisis del modo de regulación ............................ 11

1.3.2 La segunda fase de la crisis del modo de regulación ........................ 12

$1.4 \mathrm{El}$ final del MSI el inicio de la crisis de larga duración ......................... 13

Capítulo 2. Del endeudamiento externo a la nacionalización de la banca

2.1 Las etapas del endeudamiento externo ....................................... 18

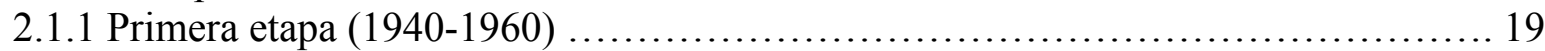

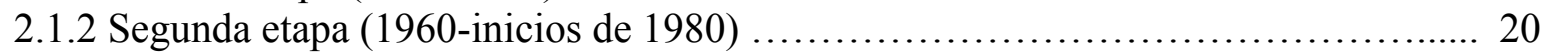

2.1.3 Tercera etapa ("La crisis de la deuda") .................................... 22

2.2 Financiarización de la economía mexicana y una nueva oligarquía financiera ....... 23

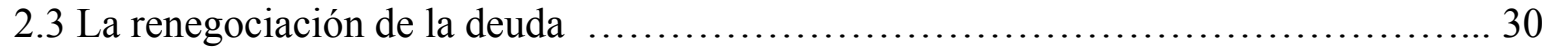

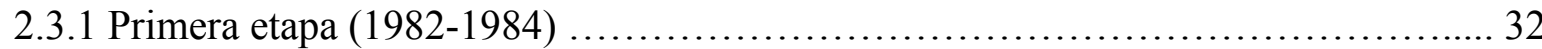

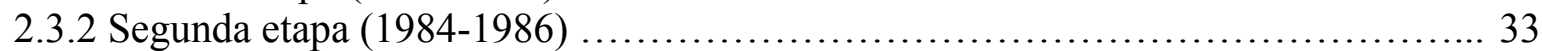

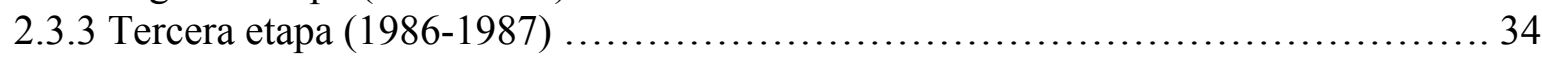

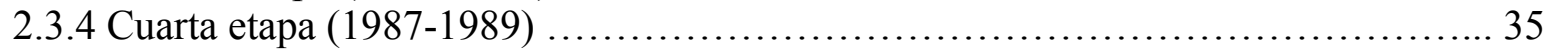

2.4 Sobre la conformación de una nueva oligarquía financiera ........................ 39

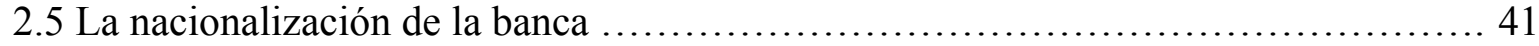

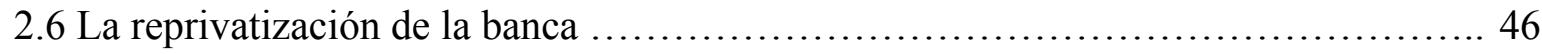

Capítulo 3. Desregulación y extranjerización de la banca durante la década de los noventa

3.1 El concepto de la Desregulación Financiera ................................. 52

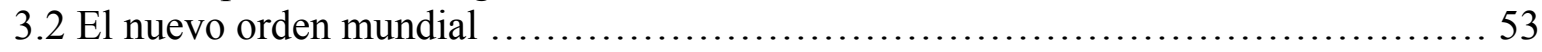

3.3 TLCAN y la banca comercial en México ..................................... 57

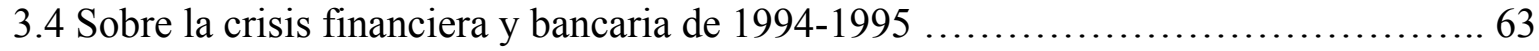

3.5 Fobaproa e IPAB, el rescate bancario ...................................... 67

3.6 La extranjerización de la banca .......................................... 70

Capítulo 4. La banca comercial extranjerizada

4.1 Un análisis de la banca extranjerizada ...................................... 76

4.2 Banca comercial en México y la crisis global de $2007 \ldots \ldots \ldots \ldots \ldots \ldots \ldots \ldots \ldots \ldots . \ldots 2$

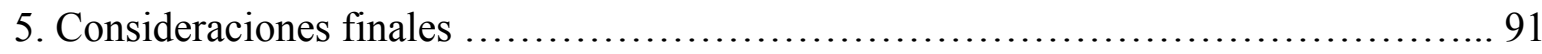

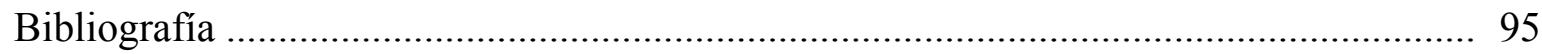




\section{INTRODUCCIÓN}

A finales de 1970, al extinguirse el Modelo de Sustitución de Importaciones (MSI) se inicia una crisis de larga duración en México, con diversas consecuencias en la vida económica y social del país. En esta investigación me concentraré en el aspecto financiero. Como se explica en el primer capítulo, se trabaja a partir de la tesis de la crisis del modo de regulación sin profundizar en la misma, pero sí haciendo una caracterización y una descripción de sus principales conceptos. Lo que es necesario para comprender sus consecuencias al comienzo de la década de los ochenta del siglo pasado.

El sistema financiero en México sufrió cambios fundamentales desde los primero años de la década de los ochenta uno de lo hechos más trascendentes es la financiarización de la economía mexicana. Ésta se fortaleció en México a partir de la crisis de la deuda de la década de los ochenta (1982), ya que tuvo como consecuencia la bursatilización de la deuda dando comienzo a la globalización financiera Correa (2010) y Soto (2009). Las transacciones financieras no necesitan realizarse forzosamente en un espacio geográfico determinado y delimitado. La emisión, compra y venta de títulos alrededor del mundo financiero no conoce fronteras.

El análisis de la financiarización es sustancial para ésta investigación ya que implicó un cambio fundamental en el funcionamiento de la banca; cambió el papel que jugaba el sector bancario hasta antes de los ochenta modificando su función como fuente principal de financiamiento a la producción en una búsqueda por obtener mayores ganancias.

Se puede decir que dado el proceso de desregulación y liberalización del sector financiero que cambiaría el tipo de financiamiento; la banca de desarrollo dejó de ser una fuente esencial de financiamiento productivo.

Sobre este hecho Girón y Levy afirman:

la banca de desarrollo redujo su importancia en la década de los ochenta en el proceso de desregulación bancaria y de las privatizaciones. En el nuevo modelo no se aceptaron interferencias del Estado en la orientación de los créditos, reduciéndose la 
participación de las instituciones que dirigían el crédito y ofrecían costos inferiores a los de mercado (Girón, Levy, 2005: 46)

Siguiendo con las modificaciones del negocio bancario; la nacionalización bancaria fue otro factor explicativo de las transformaciones de este sector, ya que posteriormente sería reprivatizada lo que implicaría una reconformación de los grupos que se apropiarían de la banca comercial en México, conformándose una oligarquía financiera encabezada por los grandes conglomerados extranjeros que han establecido una relación de sociedad con los capitalistas financieros nacionales.

Un hecho que profundizó el cambio en la banca, fue la ejecución de las reformas estructurales consideradas en la agenda del Consenso de Washington a finales de los ochenta, siendo sus principales premisas la desregulación y liberalización de la economía. Esto tuvo un impacto en el sistema financiero mexicano y particularmente en la banca comercial que posteriormente a la entrada en vigor del nuevo orden conocido por autores como Arturo Guillén (2008) (2010) como modelo neoliberal, se concretó la firma del Tratado de Libre Comercio de América del Norte (TLCAN) el cual permitió, bajo una serie de cambios a la ley, desregular dicho sector consintiendo así el establecimiento y apropiación de los bancos comerciales por grupos extranjeros.

La década de los noventa trajo consigo modificaciones sustanciales en la banca comercial, como se estudiará más adelante, siendo un momento relevante la crisis que estalló a finales de 1994 y que implicó (entre otras cosas) una apropiación casi total de la banca en manos de extranjeros principalmente grupos españoles.

Todas las transformaciones que se desataron a principios de los ochenta, se han consolidado al paso de los años mediante reformas de corte neoliberal que han sometido al sector bancario en México, a una fuerte liberalización y desregulación que ha permitido su fácil apropiación por parte de foráneos. Lo que implica una fuga de las ganancias hacia su matriz extranjera y que no exista un control nacional de un sector que es determinante en la vida económica de un país en un mundo financiarizado. 
Como se observa, éste trabajo de investigación esta enfocado en analizar hechos fundamentales para el sistema financiero en México abarcando el periodo de 1980 a 2010. Mi interés en este periodo se basa en que durante estos años es cuando se presenta el fuerte proceso de desregulación y liberalización de dicho sistema y que éste proceso desregulador fue dando forma a la actual banca comercial en el país, que ha quedado casi totalmente en manos de extranjeros, prueba de ello es que en 2010 los grupos financieros extranjeros tenían una participación en el mercado de más del 60\%.

En este contexto la investigación se guiará por las siguientes preguntas; ¿qué papel tiene la banca comercial en México?, ¿cuáles han sido las implicaciones para el sector bancario, de la inclusión de la economía mexicana al mundo financiarizado?, ¿la desregulación y liberalización financiera han incrementado la participación de conglomerados extranjeros en la banca comercial de México?, ¿cuáles son dichos niveles de participación en el mercado?, ¿el negocio bancario ha promovido la conformación de una nueva oligarquía financiera en el país?.

En base a lo anterior, el objetivo de esta investigación es analizar el proceso de desregulación, liberalización y extranjerización de la banca en México y determinar que la financiarización mundial ha implicado un cambio en el tipo de financiamiento, una reconformación en la distribución y apropiación de la riqueza por los grandes grupos capitalistas tanto nacionales como extranjeros conformándose una nueva oligarquía financiera en el país, disminuyendo la participación de la banca en el crecimiento de la economía del país.

La hipótesis que me planteo en esta investigación es la siguiente:

El tipo de financiamiento del sector bancario antes de la década de los ochenta, estaba enfocado al financiamiento de la capacidad productiva. En la actualidad dicho financiamiento se ha venido modificando de acuerdo a las transformaciones del sistema financiero global y al proceso de financiarización de la economía, dejando de tener como principal objetivo el incremento de la capacidad productiva del país, enfocándose a 
financiamientos mucho más riesgosos que le han permitido alcanzar mayores beneficios, como el mercado de derivados, la gestión de opciones y futuros financieros por mencionar algunos.

Dicha modificación ha implicado un cambio en la forma de reparto de los beneficios que son apropiados por los grandes grupos capitalistas nacionales y extranjeros, lo que ha resultado en la generación de una nueva oligarquía financiera en México con nuevos componentes, hecho que se ha reflejado en la poca contribución de la banca comercial en el crecimiento de la economía del país.

Los resultados del trabajo de investigación, se exponen en cuatro apartados y las conclusiones.

En el primer apartado se realiza un análisis sobre la crisis del modo de regulación que se iniciara a finales de 1970 en México. Se estudia su concepto y se hace una caracterización de la misma. Se ha considerado que es importante este análisis para entender porque se trabaja con el supuesto de una crisis de larga duración en el país y sus consecuencias económicas, particularmente las que corresponden al sistema financiero.

La segunda parte se centra en examinar los sucesos que modificaron de manera definitiva a la banca en México en la década de los ochenta.

El objetivo en esta parte, es analizar como el proceso de endeudamiento externo del país implicaría la financiarización de la economía mexicana. Así como entender las consecuencias de la crisis de 1982, que sería un hecho determinante en la liberalización y desregulación del sector financiero.

En el tercer apartado se estudia a la banca comercial durante la década de los noventa en la cuál el proceso de financiarización era más que contundente. Se examina con detenimiento las modificaciones que se hicieron a la ley bancaria con la firma del TLCAN en favor de extranjeros, lo que conllevó a la fuerte extranjerización bancaria en México y que profundizó la desregulación y liberalización de dicho sector. 
El análisis de la década de los noventa es clave, porque en estos años se comienza a gestar una nueva oligarquía financiera en el país conformada por los grandes grupos financieros que se fueron creando de acuerdo al proceso de extranjerización.

La última parte de la investigación esta enfocada al estudio de la participación extranjera en la banca comercial en México durante los últimos diez años. La participación se incrementó en los primeros años del nuevo siglo, lo que ha permitido a un número reducido de bancos extranjeros concentrar el negocio bancario en el país, consolidándose una nueva oligarquía financiera con características específicas. 


\section{CAPITULO 1. ANTECEDENTES DE LA CRISIS DE LARGA DURACIÓN EN MÉXICO}

En éste capítulo se estudia el concepto de modo de regulación y se analizan las características de la crisis del modo de regulación. Éste análisis tiene como objetivo explicar porque se trabaja en esta investigación con el supuesto de una crisis de larga duración que inicio en 1970, así como examinar sus consecuencias principalmente en el sistema financiero del país.

\subsection{El Concepto de Modo de Regulación}

El presente trabajo parte de la hipótesis de que México vive una crisis de larga duración, la cual inició con la salida del Modelo de Sustitución de Importaciones (MSI). Profundizar en el análisis de esta hipótesis implicaría en si misma una investigación aparte. Por lo que aquí solo presentaré algunas ideas que son claves para el entendimiento de la que - para autores como De Bernis y Arturo Guillén - es una crisis del modo de regulación.

En las crisis de regulación, cuando el proceso de acumulación y las formas en que la ganancia es apropiada por las diversas fracciones del capital no son compatibles con los procesos que permiten satisfacer las necesidades sociales; lo característico es la disputa abierta entre las fracciones del capital.

Gerard De Bernis sostiene que;

La crisis $[\ldots]$ es $[\ldots]$ un periodo largo de inestabilidad estructural de los procesos de acumulación, engendrado por las contradicciones propias de este proceso dentro del periodo precedente y la pérdida de la coherencia de los sistemas productivos preexistentes, periodo en el curso del cual pueden eventualmente ser reconstituidas las condiciones de una nueva coherencia y de nuevos procesos de regulación. (De Bernis, 1991: 144) (Citado por Vidal, 2011: 70)

Entendiendo el concepto de "modo de regulación" como;

[...] el conjunto estructurado de procedimientos sociales (nuevas formas de producción; nuevas formas de explotación del trabajo asalariado; modificación en las relaciones entre el centro y la periferia del sistema; reforma de las instituciones 
existentes y creación de nuevas instituciones, etcétera), utilizados por el capitalismo en cada fase de su desarrollo, para hacer frente a las contradicciones del proceso de acumulación del capital. (Guillen, 2007: 282).

En palabras de De Bernis;

[...] hemos admitido como definición de la regulación de la economía capitalista al "proceso de articulación de las dos leyes de la ganancia siempre y cuando condicionan al proceso de reproducción ampliada" [...] (De Bernis, 1985: 106)

\subsection{Las leyes de la ganancia}

Para que el modo de regulación sea eficaz debe existir un adecuado entendimiento entre las dos leyes de ganancia:

- La ley de la tendencia descendente de la tasa de ganancia

- La ley de formación de la ganancia media

Gregorio Vidal en un estudio realizado sobre las leyes de la ganancia, afirma que para entender su nexo orgánico, así como su propio comportamiento es necesario tener presentes las cuestiones siguientes (Vidal, 1985: 152):

a) existe una clara relación entre el comportamiento de la tasa de ganancia y la acumulación, por ello la comprensión del movimiento de la tasa implica considerar el de la masa de ganancia,

b) el funcionamiento de la ley como tal - o dicho de otra manera, las contradicciones internas de la ley como tal - implica el propio de sus causas contrarrestantes, por lo que debemos considerar en todo su alcance el proceso de concentración y centralización del capital y por lo tanto el de la formación de la cuota general de beneficio;

c) el análisis de las causas contrarrestantes nos permite observar que varias de ellas lo son en tanto consideramos la manera en que se constituye la cuota general de beneficio, con lo que nos situamos en el terreno del fraccionamiento del capital y de las leyes que lo rigen; 
d) la cuota general de beneficio, en tanto medio de asignar las partes del plusvalor a cada capital, es determinante del proceso de financiamiento y de la reproducción de los capitales individuales (...);

e) la cuota general influye decisivamente en la formación del sistema de precios y por esta vía regula todo el sistema de cambio y asignación de la riqueza en el régimen capitalista.

Tomando en cuenta los puntos anteriores se entiende que el nexo entre las leyes de la ganancia implica en si mismo un proceso de concentración y centralización del capital que viene dado por el comportamiento de la tasa, el movimiento de la masa de ganancia y las causas que contrarrestan la tendencia a la baja de la tasa. Este proceso va generando distinciones entre los capitalistas ya que se da un modo distinto en el reparto de la ganancia y en el modo de acumulación.

Cuando el modo de regulación falla, desciende la tasa de ganancia, disminuye la inversión y se restringe la demanda efectiva. Sobre este punto Guillén afirma;

Cuando un modo de regulación entra en crisis, la articulación de las dos leyes de ganancia deja de ser eficaz. La tasa media de ganancia se contrae como consecuencia del incremento de la composición orgánica del capital y del hecho de que las contratendencias (...) pierden efectividad. La baja de la tasa de ganancia desalienta el proceso de inversión y restringe la demanda efectiva. (Guillen, 2007: 283)

En México la articulación de estas leyes no ha sido eficaz dado que existe una fuerte concentración de la ganancia entre las empresas más grandes, que son en su mayoría Empresas Transnacionales (ET), las cuales han expandido su influencia en la economía mexicana.

Cierto es también, que la inversión se ha reducido notoriamente en nuestro país, que ya no resulta tan atractivo para los inversionistas, cuando tienen la opción de invertir en otros países que les ofrecen mano de obra mucho mas barata y especializada, con productos de calidad, es decir, tienen la opción de reducir sus costos y así ampliar su rango de ganancias. 


\subsection{Fases de la crisis del modo de regulación}

Dentro de esta crisis del modo de regulación y siguiendo el trabajo de De Bernis, apoyado por autores como Arturo Guillén y Gregorio Vidal, la crisis presenta dos grandes fases, que son las siguientes:

- Una primera fase donde el proceso de crecimiento se torna inestable y predominan las tendencias a la inflación y a la apertura de las economías

- Una segunda fase, donde predominan las tendencias a la deflación y al proteccionismo asimétrico ya que considera la apertura.

\subsubsection{La primera fase de la crisis del modo de regulación}

La primera fase, la ubicamos desde la ruptura de lo que fuese el sistema monetario y financiero internacional Bretton Woods en la década de los sesenta, hasta la crisis de la deuda externa en 1982.

Dentro de esta fase se presentan, altos niveles de inflación y estanflación, la internacionalización de capitales toma fuerza para la década de los setenta y se va gestando el proceso de apertura a las empresas transnacionales. Cabe destacar que su presencia en el país no necesariamente implicaba que fueran promotoras del crecimiento económico, ni del desarrollo tecnológico.

En este sentido De Bernis advierte;

[...] ante la baja de la tasa de ganancia, las fracciones más poderosas del capital del capital buscan poner en práctica nuevas técnicas destinadas a aumentar la productividad del trabajo. Estas nuevas técnicas necesitan nuevas inversiones que, en periodo de débil tasa de ganancia, no pueden ser financiadas más que con el recurso de la inflación que permite el estallido de las normas de precios ligado al debilitamiento de los procedimientos sociales; de ella se deducen fenómenos de crecimiento que pueden dar la impresión de una verdadera prosperidad [...] y una búsqueda sistemática de salidas al exterior que se manifiesta con la apertura de las naciones a los movimientos de mercancías y de capitales. (De Bernis, 1988a: 69) 
Durante esta fase al existir una baja en la tasa de ganancia y un reducido margen de financiamiento, los empresas se endeudaban. Lo que implicó un incremento en las tasas de interés desde finales de los setenta, aumentando el costo de las inversiones; "creando la posibilidad de ganancias financieras que desvían a algunas fracciones de capital de la inversión productiva conllevando a un proceso de $<<$ financiamiento $>>$ de la economía por una parte y a un descenso hacia la comercialización -de las importaciones por ejemplo" (De Bernis, 1985: 130)

En estas circunstancias, la inflación en esta fase de la crisis es el medio de financiar la inversión y la oportunidad de que las empresas obtengan una tasa de ganancia satisfactoria.

\subsubsection{La segunda fase de la crisis del modo de regulación}

Se presenta a partir de la década de los ochenta, durante el lapso de 1980-1982, los países desarrollados enfrentan una fuerte recesión, sus tasas de inflación se elevan hasta alcanzar los dos dígitos (hecho sorprendente ya que no se había presentando desde muchos años atrás) y tasas de interés reales muy altas. En contraparte los países endeudados (tal era el caso mexicano) no podían cubrir el servicio de la deuda debido al incremento de las tasas de interés.

El endeudamiento se volvió insostenible después de la caída del tipo de cambio flexible, pero la situación se agravó aún más cuando el director de la Reserva Federal (FED) Paul Volcker, decidió elevar la tasa de interés a fines de 1979.

Una parte importante de la deuda había sido suscrita a tasa variable y estaba denominada en dólares. El vuelco de la política estadounidense trastornó radicalmente la deuda (De Bernis, 2007: 534). Otros hechos se sumaron negativamente a la decisión anterior, como que en los países endeudados se cumplieran los plazos de gracia de la deuda. Los países centrales redujeron sus importaciones y hubo una reducción de la inflación que se tradujo en menor crecimiento del alza de los precios, perjudicando a los países (como México) que tenían que vender materias primas.

Es en este momento cuando ocurre lo que Gerard De Bernis llama el pasaje de la “economía de crédito internacional" a la "economía de endeudamiento internacional" (De Bernis, 1988b: 115-116), en el entendido de que el nuevo endeudamiento tiene sólo por 
objeto financiar el servicio de la deuda (De Bernis, 2007: 536).

En el proceso de endeudamiento encontramos la relación que existe entre la crisis de regulación y la financiarización de la economía mexicana. Esta relación se expresa en el sentido de que el endeudamiento se fue dando como una búsqueda de mayores ganancias de las grandes fracciones del capital; esto conllevó a un cambio en el financiamiento productivo. Dicha búsqueda hizo que los capitalistas encontraran en el sector financiero el espacio perfecto para la obtención de ganancias mayores.

Este proceso así como la bursatilización de la deuda; dieron paso a la financiarización de la economía. La forma en que se conducen los grandes capitalistas se ha transformado y ahora lo que tiene mayor importancia es la valorización del capital financiero. En este sentido Guillen afirma:

[...] la esfera financiera predetermina la esfera productiva sometiendo ésta a sus necesidades; las formas de gestión de las grandes empresas y grupos económicos se modifican, sujetando su funcionamiento a las necesidades de rentabilidad de corto plazo. Las firmas se "financiarizan", lo que importa ahora es el valor accionario de la corporación y aumentar los ingresos de la misma, mediante la participación activa de sus tesorerías en los mercados financieros (Guillén, 2007: 59)

Por ahora es suficiente lo mencionado sobre esta segunda fase de la crisis. En el siguiente capítulo se tratará a detalle, el proceso de endeudamiento externo y sus implicaciones para la economía de México.

\subsection{El final del MSI el inicio de la crisis de larga duración}

En México se vivió un esplendor económico que duraría alrededor de 20 años. Esto debido a la ejecución de un modo de acumulación de capital basado en el mercado interno en concreto la industria interna, conocido como Modelo de Sustitución de Importaciones.

Se incentivó el crecimiento de una industria que prácticamente estaba abandonada, por el anterior modo de acumulación a base de las exportaciones primarias. Este modelo se agotó al caer los precios de los productos primarios. Esta caída en los precios de dichos productos 
también se tradujo en un mayor deterioro de los términos de intercambio entre el centro y la periferia. Sobre este punto Guillén argumenta;

El deterioro de los términos de intercambio entre productos primarios y productos manufacturados era el resultado de que los países desarrollados concentraban, a través del comercio internacional, los frutos del progreso técnico, elevando de esa manera "los ingresos de los empresarios y de los factores productivos" de esos países. Mientras los precios de las manufacturas no bajaban en correspondencia con el incremento de la productividad del trabajo, los precios de los bienes primarios tendían a disminuir a pesar de las mejoras tecnológicas que se pudieran introducir en su producción. (Guillén, 2010: 20-21)

Debido a esta barrera con el exterior que impedía a los países subdesarrollados, desarrollar su mercado bajo ese mismo modelo agrario exportador; al ser incapaces de generar las divisas que su propio mercado requería. Era urgente instaurar un modelo que permitiese reestructurar el mercado y convertir a la industria nacional en el motor del crecimiento.

Fue durante el periodo de posguerra, en la década de los cuarenta del siglo pasado, cuando se empezó a gestar el modelo sustitutivo de importaciones. Un hecho a destacar es que bajo este modelo México alcanzó elevadas tasas de crecimiento ( $6 \%$ promedio anual) tasas que hasta ese momento no habían sido vistas y en la actualidad no se han vuelto ha presentar.

En este contexto, Estados Unidos debido al conflicto bélico, dejó de producir ciertos bienes manufacturados. En esta época tenía prioridad la producción de armas. Este hecho dio pie a que México, pudiese producir algunas manufacturas sencillas para su mercado interno así como para exportar a los mismos Estados Unidos. La proyección que se tenía sobre este modelo, era que pasase de una sustitución de bienes no duraderos, a duraderos y de capital, pero México fue incapaz de pasar a la sustitución difícil (bienes duraderos y de capital).

Esto debido a una falta de generación de divisas en el seno de la industria para su propia reproducción, teniendo que ser el Estado quien se encargara de financiar a la industria interna, incrementándose así el déficit del gobierno. También el déficit de la balanza 
comercial se incrementó, a consecuencia de una disminución en la exportación de productos del sector agrícola.

El sector agrario exportador, que fuese el motor de la acumulación de capital desde la misma consolidación del capitalismo en México hasta el crack de la década de 1930, sufrió un grave abandono al cambiar las estrategias del gobierno y al convertir a la industria en la fuente de la acumulación. El abandono a este sector sigue causando estragos hasta el día de hoy y aunque han existido intentos por reavivarlo, han sido en vano. Convirtiéndose este hecho en uno de los problemas estructurales más graves del país que no le ha permitido salir de la crisis.

Durante el auge de la industria interna, la prioridad asignada al desarrollo industrial provocó el descuido y rezago de la producción agropecuaria.

El sector agropecuario se enfocó en la producción de los insumos que reclamaba la industria de alimentos y a la ganadería, con lo que se desatendió la elaboración de productos básicos. Se perdió la autosuficiencia alimentaria y se requirió de importaciones crecientes de productos agropecuarios. La balanza comercial agropecuaria dejó de ser superavitaria, por lo que el sector dejó de aportar divisas para financiar el desarrollo industrial, lo que acentuó el déficit de la balanza comercial total. (Guillén, 2010: 24)

El sesgo antiexportador provocó que para 1970 el déficit presupuestal y el déficit en la balanza en cuenta corriente, representaban el 3.8\% y el 1.3\% del PIB respectivamente (Guillén, 2010: 24).

La economía se desaceleró, el PIB tuvo un bajo crecimiento del 3.1\% promedio anual, debido a un reducción de la inversión que pasó de 9.1\% promedio en 1960 a 5.3\% durante los años setenta. La inflación se aceleró, acentuando la sobrevaluación del peso (bajo el esquema de tipo de cambio fijo), hecho que se reflejo en el déficit comercial y en el déficit presupuestal que siguieron su carrera ascendente.

Se considera que el modelo sustitutivo de importaciones, durante la década de los setenta concluyó, al ser incapaz de pasar a una producción de bienes que requerían de una mayor complejidad, en muchos niveles principalmente tecnológicos. Los problemas políticos y 
sociales; como la represión estudiantil de 1968, los problemas entre empresarios y gobierno debido a la creciente intervención estatal en las decisiones económicas, provocaron un ambiente de desconfianza entre los inversionistas, presentándose de inmediato la fuga de capitales.

Es justo bajo este contexto y esta década, la de los setenta, que se da inicio a la crisis de larga duración. Como se mencionó anteriormente, la primera etapa de esta crisis presentaba una desaceleración de la economía, las tasas de crecimiento bajaron sustancialmente alrededor del 3\%, las tasas de inflación también se elevaron y el país comenzaba a incrementar su deuda con el exterior.

El gobierno de ese periodo, ejecutó una serie de reformas que le darían una nueva estructura al mercado. Entre estas reformas se proponía una reforma fiscal redistributiva, que fundamentalmente pretendía hacer pagar más impuestos a los que mas tenían, es decir el sector empresarial, es ahí donde se encuentra el fundamento del fracaso de dicha reforma, ya que las clases altas que verían afectadas sus ganancias decidieron darle una muestra de su descontento al gobierno, retirando sus capitales del país. Otra reforma se enfocaba en la apertura comercial, reorientar al sector exportador que había quedado un tanto olvidado por el sesgo antiexportador del anterior modelo. También hubo una reforma arancelaria, relajándose la carga impositiva a las importaciones. En el sector financiero también se dieron una serie de reformas. Surgen cambios en la legislación bancaria y sobre la inversión extranjera; se establece la figura de banca múltiple y se autorizan las sociedades de inversión, en palabras de Gregorio Vidal:

[...] se trata de gestar mecanismos que permitan una mayor centralización del capital a la vez que se logre ampliar la capacidad de financiamiento desde la banca comercial, compatible con procesos de modernización de la planta industrial. La reforma incluía la promoción de las exportaciones manufactureras y el pasaje de un manejo de las importaciones vía permisos previos a la de aranceles. (Vidal, 2002: 82)

Debo indicar que para esta investigación es pertinente tener en cuenta los hechos que se desarrollaron líneas arriba, ya que son fundamentales para explicar los cambios que se dieron a finales de la década de los setenta en la economía del país. La crisis del modo de 
regulación no es el objeto de estudio, pero es importante su análisis ya que este trabajo gira en torno a una crisis de larga duración.

El análisis anterior nos permite avanzar hacia el problema del endeudamiento externo que el país vivió durante la década de los ochenta, así como los hechos que siguieron a dicho problema; la crisis de 1982, la apertura y desregulación de la economía que se intensificaría a inicios de los noventa y las transformaciones en la estructura financiera que implicó este proceso. Esto será desarrollado en los capítulos siguientes. 


\section{CAPITULO 2. DEL ENDEUDAMIENTO EXTERNO A LA NACIONALIZACIÓN DE LA BANCA}

El siguiente capítulo se enfoca en examinar los hechos que influyeron en la transformación del sistema financiero durante el decenio de 1980. Éste análisis tiene por objetivo estudiar el proceso de endeudamiento externo que implicó la financiarización de la economía mexicana. También se estudia la crisis de 1982 como un momento determinante en la historia económica de México, al tener como consecuencias la liberalización y desregulación financiera.

\subsection{Las etapas del endeudamiento externo}

Dado el contexto descrito líneas atrás, me detendré en analizar el proceso de endeudamiento del país como un hecho fundamental para tratar de explicar la crisis en que vive la economía de México desde hace ya varias décadas y como dicho endeudamiento significó la introducción del país al proceso de financiarización.

Es pertinente mencionar que en esta investigación se hará una descripción del proceso de endeudamiento externo del país en fases o etapas, en base al trabajo de algunos autores como se observará en los siguientes párrafos.

El endeudamiento externo de México y de muchos países de Latinoamérica no fue un proceso que se diera de manera espontánea sino que contrario a eso, recorrió un largo camino. Autores como Rosario Green afirman que dicho proceso se inicio desde el siglo XIX;

La deuda pública externa de México es tan antigua como el propio estado, si bien no en todos los momentos ha tenido la misma estructura ni igual significación ni mucho menos, similares consecuencias. Iniciada en 1824 con la llamada Deuda de Londres para la construcción del ferrocarril, conoce una primera etapa que llega hasta 1914 [...] (Green, 1981: 336)

En este trabajo el análisis no pretende ir tantos años atrás, ya que esto significaría rebasar los alcances de la investigación. Por lo tanto, el proceso de endeudamiento se analizará ya entrados los años cuarenta y cincuentas del siglo pasado y dicho proceso se dividirá en tres etapas. Se debe mencionar que la periodización como a continuación se presenta, fue realizada por la autora de este trabajo con base a la literatura revisada. 


\subsubsection{Primera etapa (1940-1960)}

Durante esta etapa el proceso de endeudamiento se dio como parte de la política para incentivar la industria interna del país, aplicada por el gobierno mexicano de esos años. En este sentido Green argumenta;

[...] la deuda pública externa es un componente marginal y errático del panorama económico nacional. El empleo del crédito externo se mantiene a bajo nivel como resultado de diversos factores, entre los que destacan: la política fuertemente nacionalista del régimen... la acumulación de divisas en cantidades apreciables; el mantenimiento por un tiempo de una situación favorable para las exportaciones mexicanas en los mercados internacionales; la importante aportación de divisas con que otros renglones de la cuenta corriente contribuían a la balanza de pagos mexicana; y la existencia de un aparato institucional sobre el cual se hicieron descansar las bases de un proyecto nacional de desarrollo que tenía como meta la industrialización del país. (Green, 1981: 336)

Para Guillén (1989) durante esta primera etapa, el endeudamiento externo es un factor de estímulo al crecimiento económico y no existen problemas serios para cubrir su servicio. Tomando en cuenta que es durante estos años donde el país conoció sus mayores tasas de crecimiento económico y en donde el sistema productivo nacional era el eje de la acumulación.

Para Eugenia Correa (1992) esta primera etapa abarca de finales de los años cuarenta hasta finales de la década de los cincuenta. La autora destaca el hecho de que la deuda actuó para aliviar los déficits comerciales, que fueron característicos del proceso industrializador.

Durante esta primera etapa podemos decir que el endeudamiento externo no representaba aún un problema grave para la economía de México y que más bien sirvió para fomentar un nuevo modelo donde la base de acumulación sería la producción nacional. Pero al no cumplirse las expectativas que se habían generado con este modelo los problemas económicos del país se incrementaron y con ellos el de la deuda externa. 


\subsubsection{Segunda etapa (1960- inicios de 1980)}

En esta etapa la deuda externa se vuelve un verdadero problema para el país ya que por la compleja situación que había dejado el modelo a base de la industrialización interna, el gobierno mexicano comenzó a contratar deuda para cubrir la propia deuda. Agravándose cuando la FED decide elevar la tasa de interés a finales de 1979.

Una parte importante de la deuda había sido suscrita a tasa variable y estaba denominada en dólares. El vuelco de la política estadounidense trastornó radicalmente la deuda (De Bernis, 2007: 534). Otros hechos se sumaron negativamente a la decisión anterior, como que en los países endeudados se cumplieran los plazos de gracia de la deuda, los países centrales redujeron sus importaciones y hubo una reducción de la inflación que se tradujo en menor crecimiento del alza de los precios, perjudicando a los países (como México) que tenían que vender materias primas.

Guillén asevera que esta etapa coincide,..., "con la primera fase de la crisis de largo plazo del capitalismo que se inicia a finales de los años sesenta y persiste hasta nuestros días. [...] Se inicia un proceso inflacionario de cierta importancia con tasas anuales de dos dígitos, se agudizan el desequilibrio externo y la crisis fiscal del Estado y el mercado financiero interno deja de crecer a tasas satisfactorias" (Guillén, 1989: 47)

Más adelante afirma también que la deuda externa se cuadruplica, al pasar de 5 mil millones de dólares en 1970 a 20 mil millones dólares en 1975 y que para ese mismo año el servicio de la deuda representaba el 35.5 por ciento aproximadamente de las exportaciones de mercancías y servicios.

El mismo autor destaca la relevancia que tuvo en el endeudamiento externo del país, lo que denomina como el "auge petrolero de 1978-1981"; en el cual el gobierno de México confió el crecimiento económico del país a la producción y exportación de petróleo dadas las condiciones en favor del alza de los precios internacionales de dicho producto. El gobierno tenía expectativas de que el país se convertiría en potencia industrial con los ingresos de divisas provenientes de las ventas de petróleo al exterior. La realidad fue distinta a la que el gobierno esperaba; 
Bastó la primera baja importante del precio del petróleo a mediados de 1981 para que el castillo de naipes del auge y el crédito se viniera abajo. Ante los primeros signos de contracción y de desconfianza en el seno de la burguesía, el gobierno reacciono bombeando aún más la máquina del crédito para mantener el tipo de cambio, frenar la fuga de capitales y cubrir el servicio de la deuda. Esta política fue respaldada en un principio por el FMI y la banca transnacional. Los créditos se pusieron a la orden del día. (Guillén, 1989:60)

El auge petrolero, trajo consigo un incremento en los niveles de endeudamiento que de 1978-1982 fue de 43600 millones de dólares, más del doble de los 18200 millones contratados durante los cuatro años previos.

El proceso llevó en 1982 a una profundización de la crisis estructural y a una nueva recesión cíclica más severa que la de 1976-1977, combinada con una inflación de más de 100 por ciento, una devaluación del peso cerca del 250 por ciento, una incontrolable fuga de capitales y una crisis financiera que conmovió el sistema financiero internacional. (Guillén, 1989: 51)

Rosario Green destaca sobre esta fase del endeudamiento lo siguiente:

[...] la deuda pública externa se convierte en el mecanismo de ajuste ideal con base en el cual el gobierno mexicano resuelve tanto los desequilibrios del sector externo como su déficit presupuestal, sin alterar la estructura interna de poder. Ello evidencia, entre otras cosas, su debilidad para negociar con los diversos sectores sociales de captación y movilización de recursos internos (reforma fiscal, control de importaciones, etcétera.) (Green, 1981:337)

Respecto de donde provenían los recursos de la deuda Correa plantea que:

Durante esos años tienen singular importancia para la región recursos procedentes de organismos multilaterales -Banco Mundial, Banco Interamericano de Desarrollocontratados por los gobiernos o con su garantía y, la deuda privada no garantizada procedente de la banca comercial estadounidense con una fuerte expansión en Argentina, Brasil, México y Perú. (Correa, 1992: 62) 
Esta etapa representó la más grave del proceso de endeudamiento, ya que implicó que México reforzará lazos con los organismos internacionales y que se generará una dependencia hacia el exterior. Lo que daría paso años después al establecimiento de programas de ajuste que poco harían por el crecimiento económico del país o por la eliminación de la deuda elementos que según dichos organismos (FMI, Banco Mundial), eran el objetivo de sus programas de ajuste. Sobre este punto se ahondará más adelante, en la parte relacionada a la renegociación de la deuda.

\subsubsection{Tercera etapa ("La Crisis de la deuda")}

El endeudamiento externo que había iniciado décadas atrás, comienza una nueva etapa en el año 1982 con el estallido de la "crisis de la deuda externa", cuando México se declara incapaz de solventar los compromisos de su abultada deuda.

La nueva etapa del endeudamiento internacional estaría caracterizada por la contracción brusca de los créditos externos al tercer mundo. Los escasos créditos que reciben los países endeudados dejan prácticamente de servir como instrumento de fomento de la producción y de la inversión, para servir de manera principal como mecanismo para garantizar el pago del servicio de la deuda $\mathrm{y}$, sobre todo, los intereses de la misma. (Guillén, 1989: 52)

Para Eugenia Correa el proceso de endeudamiento durante la década de los ochenta tiene un fuerte vínculo con el crecimiento del euromercado, años durante los que se incrementó aceleradamente el monto de la deuda procedente de la banca comercial y que cambió radicalmente el perfil acreedor de la región y con ello las condiciones de su servicio. (Correa, 1992: 63)

Una característica que no debe pasar desapercibida del endeudamiento con el exterior, es de donde provenían los recursos. Este punto es interesante ya que los países endeudados tenían una fuente de créditos; en un principio eran organismo internacionales y banca oficial, pero posteriormente se agregaría la banca privada que en ningún momento puso límites a los créditos que se otorgaron, nunca pensaron que ocurriría si alguno de los endeudados no pudiese seguir cubriendo su deuda. 
Carlos Rozo, sobre el papel que jugó la banca privada internacional en el endeudamiento externo afirma que;

[...] el abandono de la política crediticia conservadora y pasiva de los banqueros hacia el tercer mundo, que los llevó a entrar en líneas de actividad previamente reservadas a la banca oficial internacional. Los prestamos para proyectos de infraestructura y para resolver déficits presupuestales y de balanza de pagos se convirtieron en una actividad central de la banca privada internacional. Es nuestra consideración que estos pasos abrieron la puerta grande que propició y alimentó el desorbitante endeudamiento externo, no sólo en el tercer mundo sino también en los propios países industrializados de los cuales EU es el principal. (Rozo, 1987: 88)

Después de que estallará la crisis de la deuda, lo que continuó para la economía mexicana fueron años de renegociación de la deuda externa con los organismo internacionales. Este proceso de renegociación así como sus consecuencias, se describen en los párrafos posteriores.

Pero antes, debo poner énfasis en examinar un hecho que trajo como consecuencia el endeudamiento externo de la economía mexicana; la financiarización. Me detendré en su conceptualización y en el análisis del surgimiento de una nueva oligarquía financiera. Esto es importante ya que no debe entenderse como un fenómeno aparte del endeudamiento, sino como una consecuencia del mismo. Esto se hará en el siguiente apartado y después se retomará el proceso de renegociación de la deuda.

\subsection{Financiarización de la economía mexicana y una nueva oligarquía financiera}

En México existieron hechos característicos del endeudamiento externo como la entrada al por mayor de Inversión Extranjera (IE) y una fuerte entrada de empresas transnacionales. Pero uno de los hechos sustantivos fue la financiarización, ya que determino un cambio en el tipo de inversión. La cual se ve influenciada por la obtención de mayores ganancias, volviéndose mas atractivas las inversiones en el sector financiero que en el sector productivo y esto trae como consecuencia cambios radicales en la conformación de los grupos en el poder tomando mayor fuerza los grupos financieros. 
Al respecto Vidal argumenta;

[...] la crisis es siempre un periodo de inestabilidad en las estructuras, en las formas en que la economía se reproduce. Es una época en que los medios para obtener y acrecentar ganancias no son necesariamente compatibles con la ampliación de la capacidad de producción. Menos aún hay relación entre incremento de los beneficios para algunos y mantenimiento de las condiciones sociales de la acumulación. Durante estos periodos cobran fuerza los hechos financieros. Los capitales se desplazan al exterior de diversas maneras en la búsqueda de beneficios. En un punto del proceso se genera un desajuste en las balanzas de pagos de las mayores economías que no tiene punto de retorno hasta la fecha. El endeudamiento internacional conoce sucesivos incrementos y va incorporando mercados y procesos económicos diversos. El avance de los mercados financieros internacionales se da acompañado por un incremento de la inversión extranjera directa (IED). Sin embargo, a diferencia de lo que sucedió hasta finales de los años sesenta, las nuevas inversiones en el exterior efectuadas por grandes empresas no necesariamente mantienen y refuerzan la coherencia de las estructuras productivas de los países de origen de la IED. (Vidal, 2011:71)

El mismo autor en otro texto señala que;

Las adquisiciones de acciones en manos del capital extranjero, la compra de empresas que pertenecen a otros capitales nacionales, la participación con el Estado en diversas compañías e incluso la formación de nuevas empresas es una práctica que cobra gran significación [...] un conjunto de las grandes fortunas del país se reestructuran e incluso se desarrollan formas de operar del capital que antes no habían aparecido en nuestra economía. Las sociedades de inversión, las sociedades tenedoras de acciones y otras formas propias de los grupos financieros cobran importancia (Vidal, 1989: 117)

Siguiendo esta idea, en palabras de Carlos Rozo;

La autonomía relativa que ha adquirido el circuito del capital-dinero frente al del capital productivo se postula, entonces, como la razón principal de la inestabilidad monetaria internacional que ha favorecido que la especulación caracterice a los asuntos financieros y que la ganancia de capital haya adquirido personalidad propia 
frente a la ganancia de producción. Es en este contexto en el que ocurren las transformaciones estructurales y operacionales del sistema bancario y crediticio desde los inicios de los años setenta en cuyo proceso los bancos han pasado de intermediarios de la circulación financiera a sólidas empresas capitalistas participes en el complejo entrecruzamiento de capitales. Esta situación ha introducido a la banca a nuevos campos de actividad como arrendamientos, facturaciones, servicios de especialistas fiscales, créditos documentarios, financiamiento al comercio, administraci6n de prestamos, sistema internacional para manejo de efectivo y consultoría financiera. (Rozo, 1987: 88)

Los capitales financieros que se fortalecen durante el proceso de crisis se amparan en las ideas del libre cambio, que avanzan destruyendo la coherencia en los procesos sociales de reproducción de las economías, como medio para acrecentar sus ganancias. (Vidal, 2011:73)

Es un periodo en que próspera la destrucción sistemática del derecho al trabajo para permitir la libre explotación de los trabajadores, la impugnación de los sistemas de protección social [...] la privatización de los sectores públicos a fin de ampliar la zona de extracción de plusvalía (De Bernis, 1988:53)

Importa destacar que existe un ambiente macroeconómico que ha propiciado la expansión financiera. Se ha instalado una radical incertidumbre sobre el comportamiento de las series de precios y de costos debido a la volatilidad de las tasas de cambio y a la inestabilidad de la tasas de interés. Ambos hechos se han consolidado, permitiendo que los capitales que operan en las colocaciones financieras desarrollen prácticas para beneficiarse de la situación. Son las formas en que algunas fracciones el capital financiero están obteniendo cuantiosos beneficios y ganando poder. (Vidal, 2011: 72)

Lo anterior muestra que durante estos años es cuando en México se dan cambios en los tipos de inversión dado el proceso de apertura económica y del fortalecimiento de la esfera financiera. Ahora el objetivo principal de los grandes grupos capitalistas es incrementar sus ganancias recurriendo a practicas que aunque impliquen un mayor riesgo resultan mucho 
mas rentables. Esto trae como consecuencia que la inversión en la producción pase a un segundo termino y que haya una reconfiguración en los grupos de poder, ya que estos comienzan a conformar una nueva oligarquía financiera, que en palabras de Vidal;

Es sin duda una oligarquía financiera [...] que vive del corte de cupón. Es la expresión más destacada del avance de la financiarización, de una distinta relación entre industria, comercio y finanzas sobre la base de una economía internacional de endeudamiento que permite a un reducido grupo de grandes financieros construir sus ganancias apropiando excedente de muy diversas fuentes, incluidos los presupuestos gubernamentales, los patrimonios de familias, bienes necesarios para la alimentación de la población, las instituciones del Estado del bienestar y las propias condiciones de sustentabilidad de la vida en el planeta tierra. (Vidal, 2011: 88)

Es mediante este cambio en el tipo del financiamiento que México comienza su inmersión en lo que para algunos autores como Chesnais (2000) y Boyer (1986) es un régimen de acumulación dominado por las finanzas o en la financiarización de su economía como lo denominan autores como Epstein (2001).

Por lo analizado en las líneas anteriores podemos plantear que la manera en que se fue dando el proceso de endeudamiento de la economía mexicana, implicó la inserción del país en la financiarización e implicó también una modificación en el operar del capital financiero en la vida económica del país.

Antes de continuar cabe mencionarse que se entiende por financiarización; Epstein la define cuando se refiere a "la creciente importancia de los mercados financieros, los motivos financieros, las instituciones financieras y las élites financieras en la operación de la economía y el gobierno de las instituciones, tanto a nivel nacional como internacional” (Epstein, 2001:1).

Para reforzar el concepto anterior, en palabras de Chesnais;

Este régimen que ha surgido de la liberalización y la desregulación en el triple ámbito de la escena financiera, los intercambios comerciales y las inversiones productivas. Por esta razón se trata de un régimen mundializado, aunque no puede olvidarse que 
esa mundialización es selectiva y jerarquizada, y que las trayectorias económicas y sociales previas de los países han dado lugar a formas de integración muy variadas. Y debe definirse como un régimen dominado por lo financiero por numerosas razones: su origen y su consolidación se han producido a medida que se ha reforzado el grado de concentración financiera a partir de 1980-1981, los inversionistas financieros han conseguido que los gobiernos apliquen políticas que les garantizan tipos de interés elevados y una gran seguridad en el cobro de todos los ingresos vinculados a los préstamos (Chesnais, 2000:46) (citado por Girón, 2010: 59)

Hyman Minsky denomina como capitalismo del gerente monetario, a los hechos que en la actualidad predominan en el mundo de la economía y lo define como: la etapa actual del capitalismo dominada por fondos altamente apalancados que buscan maximizar sus beneficios en un entorno de riesgos sistemáticos y una tendencia a la baja de los precios. Con poca regulación y supervisión de la instituciones financieras (Citado por Wray, 2009: $55)$.

Más adelante advierte que en el mundo desarrollado, ha habido una transición de largo plazo de la banca altamente regulada hacia un "mercado basado" en las instituciones financieras.

Así, durante la década de los ochenta y los noventa la economía se globaliza y financiariza (Guillen, 2007: 63). México se introduce a este proceso de financiarización cuando se incrementa la deuda con el exterior y se comienza a pagar deuda con deuda (endeudamiento tipo Ponzi).

Desde el comienzo de este trabajo de investigación se ha insistido en las ideas de que al ser México parte de la financiarización, surge un cambio en el tipo de inversión y que ha fomentado la conformación de una nueva oligarquía financiera; por lo que me parece pertinente que antes de seguir fortaleciendo dichas ideas hay que introducir un concepto clave, el de capital financiero. El cual viene ha reforzar la idea de la formación de las grandes grupos financieros y su posicionamiento en la economía del país (y del mundo). 
Este concepto queda expresado como una relación entre el sector industrial y el bancario, pero que dado el proceso en que los grandes capitalistas bancarios van adquiriendo mayor poder, el capital financiero toma un sentido propio.

En palabras de Hilferding quien tiene un amplio estudio al respecto;

[...] llamo al capital financiero al capital bancario, esto es, capital en forma de dinero, que de este modo se transforma realmente en capital industrial [...]

El capital financiero se desarrolla con el auge de la sociedad por acciones y alcanza su apogeo con la monopolización de la industria [...] son los bancos los que disponen del capital bancario y el dominio sobre ellos lo tienen los propietarios de la mayoría de las acciones bancarias. Es evidente que, con la concentración creciente de la propiedad, se identifica cada vez más los propietarios del capital ficticio, que da el poder a los bancos [...] (Hilferding, 1985, 247-248)

Sobre el concepto de capital financiero Gregorio Vidal menciona que;

[...] una nueva fracción del capital que en efecto surge de una particular relación entre producción y financiamiento de la acumulación.

Es un capital que opera en - o cuya circulación abarca - la industria, el comercio, la agricultura y 1 os servicios (incluidos los financieros) a partir de formas monopólicas. Su movimiento se asienta en la separación del atributo del capital, como capital en funciones, del que posee como capital propiedad. En tanto capital propiedad, esta fracción constituye su valorización incorporando al ámbito de la circulación que le es propio, a los más variados espacios y hechos de la actividad económica. Salarios, rentas de las diversas fracciones del capital y de sectores pequeños burgueses, ingresos y egresos públicos van siendo incluidos en su movimiento. Además, é1 mismo se constituye en soporte del crédito, que paso a paso es el fundamento de la moneda. (Vidal, 1987: 96-97)

Mas adelante el mismo autor afirma que; "si en su origen, el capital financiero surge de la concentración de la producción y la integración y ensambladura de la industria y los 
bancos, una vez constituido adopta un movimiento propio, que entre otros hechos entraña una modificación de las relaciones entre producción y financiamiento.” (Vidal, 1987: 98)

Para este trabajo es pertinente el análisis de los conceptos anteriores, por como se fueron dando los cambios en la estructura financiera del país durante la década de los ochenta implicando la inmersión de México en la financiarización, la cual se reforzó durante el proceso de la renegociación de la deuda que se analizará mas adelante.

Antes de pasar al estudio del proceso de renegociación, debo destacar un hecho que es inherente al proceso de endeudamiento descrito líneas arriba; el que concierne al papel que México desempeña a nivel internacional como país endeudado.

Este hecho lo convierte no sólo en un país dependiente de las organismos internacionales y de Estados Unidos (por ser uno de sus mayores acreedores), sino que también lo convierte en "exportador neto de capitales", es decir, el endeudamiento y las posteriores renegociaciones con los organismos internacionales no permiten que se acabe con la deuda y esto implica que México siga pagando la deuda eternamente, dirigiendo al exterior montos enormes de dinero que han dejado de ser utilizados en la inversión en la producción nacional o en el bienestar social.

Como se puede observar en el cuadro 1; durante los años sucesivos a la crisis de la deuda y hasta 1989, las transferencias de capital que México realizó se aproximaron a los 70 mil millones de dólares una cantidad bastante significativa.

Otra información relevante que aporta este cuadro es la cantidad que se pagó por concepto de intereses, alcanzado la mayor cifra en 1984 que fue de 11, 300 millones de dólares. Arturo Guillén, respecto a lo señalado líneas atrás afirma que;

[...] nuestro país ha mantenido la situación de exportador neto desde 1982, trasladando un promedio alrededor de 12 mil millones de dólares anuales [...] en el periodo 1982-1987 México trasladó al exterior recursos totales equivalentes a 72300 millones de dólares, cifra a todas luces descomunal que pone de bulto el peso enorme 
que tiene la deuda externa en la economía nacional. Esta cifra equivale a cerca de la mitad de la transferencia efectuada por América Latina que en el mismo periodo fue de 150 mil millones. (Guillén, 1989: 95)

Cuadro 1. México: transferencias netas de capital al exterior 1980-1989.

(Miles de millones de dólares)

\begin{tabular}{cccc}
\hline Año & $\begin{array}{c}\text { Servicio de la } \\
\text { Deuda Externa }\end{array}$ & $\begin{array}{c}\text { Intereses de la } \\
\text { Deuda Externa }\end{array}$ & $\begin{array}{c}\text { Transferencias } \\
\text { Netas }\end{array}$ \\
\hline 1982 & $15,684.25$ & $11,153.12$ & $-1,798.99$ \\
1983 & $14,825.38$ & $9,994.17$ & $-15,804.49$ \\
1984 & $16,959.70$ & $11,302.19$ & $-12,143.94$ \\
1985 & $15,292.62$ & $10,220.39$ & $-10,932.35$ \\
1986 & $12,943.52$ & $8,375.24$ & $-6,648.20$ \\
1987 & $12,086.92$ & $8,326.08$ & $-4,227.08$ \\
1988 & $15,473.21$ & $8,712.20$ & $-8,213.67$ \\
1989 & $15,563.39$ & $9,310.44$ & $-9,597.95$ \\
\hline
\end{tabular}

Fuente: Elaboración propia con información de World Bank, World Bank Data, World Development Indicators and Global Development Finance, edición internet, www.worldbank.org, consultado en Marzo de 2012.

Eugenia Correa comparte el argumento anterior al decir que;

Durante 1982-1985 la región se configuró [...] en exportadora neta de capitales. En esos cuatro años se remitió por concepto de intereses más de 134000 millones de dólares (incluyendo intereses generados por la deuda de corto plazo) y se pagaron amortizaciones por más de 104000 millones de dólares (incluyendo amortizaciones de la deuda de corto plazo que fueron como saldo desfavorables para la región en 45 000 mil millones de dólares) (Correa, 1992: 82)

El pago de la deuda externa ha implicado que México se convirtiera en un exportador de capital y este es un hecho que se ha venido fortaleciendo a lo largo del camino de endeudamiento y de renegociación de la deuda como se analizara a continuación.

\subsection{La renegociación de la deuda.}

Después de que en agosto de 1982 México se declarara incapaz de cubrir el servicio de su deuda externa y de que diera inicio la que sería conocida como la "crisis de la deuda"; siguieron una serie de renegociaciones con los organismos internacionales encabezados por 
el FMI y el Banco Mundial que más que ayudar al país a salir del problema de la deuda, implicaría un encadenamiento a la misma favoreciendo solo a los acreedores.

El proceso de renegociación de la deuda en México en esta investigación será analizado en etapas con base en autores, como Arturo Guillén y Eugenia Correa.

Para Guillén la renegociación de la deuda se inició con la firma de la primera Carta de Intención con el FMI en 1977 pero aclara que;

"El acuerdo de contingencia de 1977 no fue en un sentido estricto, un acuerdo de renegociación de la deuda como los que se comenzarían a aplicar en forma generalizada desde 1982, sino más bien un programa de estabilización "clásico" originado por la agudización de los desequilibrios fiscal y externo" (Guillén 1989: 52)

Basados en el análisis hecho por Guillén, en esta investigación la renegociación de la deuda será trabajada en cuatro etapas, omitiremos la firma de la Primera Carta de Intención, ya que como se mencionó no es en si misma una renegociación. Solo señalaré que en la época en que se firma la primera Carta, México vive una fuerte recesión cíclica, acompañada de inflación, déficit financiero del sector público, fuga de capitales y una fuerte devaluación del peso, dada esta situación el gobierno mexicano decide firmar un acuerdo con el FMI el cual tenía como elementos principales: limitar el endeudamiento a un máximo de 3 mil millones de dólares, liberalizar el comercio exterior del país, restringir el gasto público y el crecimiento del sector paraestatal y se fijo un tope salarial como condición para firmar el acuerdo.

Si bien este acuerdo no es una renegociación de la deuda como tal, si se vislumbra que es uno de los primeros pasos hacia el establecimiento de políticas de corte neoliberal en el país ya que era más bien un programa de estabilización "clásico" y el pago del servicio de la deuda se seguía cubriendo igual. 
Las cuatro etapas de la renegociación de la deuda que serán examinadas en este apartado, se hicieron con base en el análisis de Arturo Guillén (Guillén, 1989: 55). La etapas son las siguientes:

- 1982 , programa de rescate de corto plazo y acuerdo con el FMI, posterior a la crisis de agosto

- 1984 acuerdo de recalendarización a más largo plazo (multianual) del servicio de la deuda con la banca transnacional

- 1986 , nuevo acuerdo con el FMI y nuevo programa de rescate

- 1987 a la fecha (1989), búsqueda de nuevos instrumentos para aligerar el peso de la deuda externa

\subsubsection{Primera Etapa (1982-1984)}

En esta primera etapa el proceso de renegociación con el FMI duró aproximadamente un año.

El acuerdo de "rescate" se firmo el 20 de agosto de 1983. Consistió en la restructuración de la deuda pública con vencimiento entre el 23 de agosto de 1982 y el 31 de diciembre de 1984. Involucró la renegociación de 20 mil millones de dólares, aproximadamente un cuarto de la deuda acumulada hasta el momento en que estalló la crisis. Implicó un crédito jumbo de 5 mil millones de dólares con la banca transnacional, uno de contingencia con el FMI de 3 años por 4500 millones y nuevos créditos por parte de la banca multilateral (Banco Mundial y BID) por 2000 millones (Guillén, 1989: 61)

La firma del acuerdo con el FMI, implicó la entrada en vigor del Programa Inmediato de Reordenación Económica (PIRE) y el Plan Nacional de Desarrollo que era la manifestación mas clara de las políticas de corte neoliberal y de su establecimiento en el país. Las bases de estas políticas de ajuste eran: la reducción del gasto público del Estado, un ajuste a los precios y tarifas del sector público, el aumento a los impuestos al consumo, el reforzamiento de los controles salariales, la liberación de precios internos y la fijación de una tasa de cambio flexible orientada a impulsar las exportaciones y frenar las importaciones. (Guillén, 1989: 62) 
Es claro que esta renegociación estaba planteada de tal forma que México resultó poco favorecido y los servicios generados por la deuda siguieron pagándose. No había una propuesta para eliminar realmente el endeudamiento del país, sino que dicha renegociación facilitó la entrada en vigor de las políticas neoliberales, que con el paso del tiempo se empezaron a hacer presentes en la vida económica de México; con una restructuración del sistema productivo que ahora se enfocaría a las exportaciones, así como por la apertura a los capitales extranjeros y la liberalización de la economía.

\subsubsection{Segunda Etapa (1984-1986)}

México inició una siguiente etapa en las renegociaciones de la deuda con el FMI y la banca comercial en 1984 que tendían a reprogramar la deuda a más largo plazo, el acuerdo anterior había sido planteado para resolver problemas a más corto plazo.

Una vez más el gobierno mexicano aceptaba entrar en negociaciones bilaterales y aceptando condiciones que, aunque mejores en relación a 1983, convenían en lo esencial, a los intereses de la banca transnacional. Era indiscutible que para ésta seguía resultando provechoso refinanciar la deuda en vez de enfrentarse a la posible aplicación de medidas más radicales y unilaterales de parte de los deudores.

Este acuerdo implicó una recalendarización de la deuda a más largo plazo, así como, una reducción de los márgenes y la eliminación de las comisiones para el capital renegociado. Implicó también otros cambios como; en el caso de la tasa de interés, la sustitución de la prime rate por la libor y la posibilidad de convertir algunos créditos denominados en dólares a otras divisas.

Guillén hace el análisis detallado de esta renegociación y argumenta;

El acuerdo cubrió 48500 millones de dólares, que representaban la totalidad de la deuda pública contratada con la banca comercial e incluía la reprogramación de los montos negociados en 1983 y del préstamo sindicado de 5 mil millones conseguidos ese año...con esta renegociación se modificó el perfil de la deuda [...] se consiguió un nuevo préstamo por 3800 millones dólares en la banca internacional. (Guillén, 1989: 68) 
Si bien esta reprogramación de la deuda significó que el peso de la deuda se aligerara, ya que permitió extender el tiempo de las amortizaciones, siguió representando una carga sustantiva para la vida económica del país.

\subsubsection{Tercera Etapa (1986-1987)}

En octubre de 1985 en la reunión del FMI, se da comienzo con lo que podríamos considerar una tercera etapa en las renegociaciones de la deuda.

Es en este momento cuando a nivel internacional se manifiesta que los acuerdos anteriores no resolvían el problema de la deuda externa y que los programas de ajuste promovidos por el FMI no cumplían con la recuperación y el crecimiento económico de los países endeudados.

Es el secretario del tesoro de EUA James Baker, quien lanzó una propuesta que llevaría su nombre; el Plan Baker, que consistía básicamente en aumentar el financiamiento de la banca internacional hacia los países más endeudados en 27000 millones de dólares en los tres años siguientes. Claro está que los países debían continuar con sus planes de ajuste.

"La propuesta Baker implicó para los prestatarios, la necesidad de un crecimiento fuerte y sostenido de las economías deudoras, a fin de solucionar el problema del servicio de la deuda sobre éstas, sin cuestionar su cuantía sino en términos relativos respecto del desempeño de las economías, compelidas a generar los excedentes en divisas necesarias para cubrirlo." (Correa, 1992: 97)

El plan Baker sugería que los países deudores que adoptaran su iniciativa deberían aplicar estrategias económicas que incluyeran como elementos centrales los siguientes (Guillén, 1989: 74):

1. Creciente confianza en el sector privado y menor confianza en el gobierno para incrementar el empleo, la pobreza y la eficiencia.

2. Acciones del lado de la oferta "para movilizar los ahorros domésticos y facilitar la inversión tanto doméstica como extranjera (...)

3. Medidas de apertura del mercado para alentar a la inversión directa extranjera y los flujos de capital, así como liberalizar el comercio incluyendo la reducción de los subsidios a la exportación. 
Sobre el contenido de este plan, Eugenia Correa, afirma:

El Plan Baker incluyó las líneas de política económica que los gobiernos debían adoptar, con el siguiente contenido: 1] la privatización de las empresas públicas deficitarias o ineficientes; 2] el desarrollo más eficiente del mercado accionario; 3] la mejora del comportamiento de la inversión nacional y extranjera; 4] una reforma fiscal que promueva la inversión y el crecimiento 5] la liberalización comercial y la racionalización de los regímenes de importación. Planteó además la necesidad de una cooperación más estrecha entre los organismos internacionales, lo que devino rápidamente en la "condicionalidad cruzada". (Correa, 1992: 98).

Este plan no ofreció una salida al problema del endeudamiento, fue solamente un paliativo para dicho problema. La realidad es que representó la clara intensión del gobierno estadounidense y de los organismos internacionales por establecer y ejecutar a la brevedad en México, las políticas neoliberales.

La renegociación de la deuda externa solo sirvió como velo para llevar a cabo su verdadera intención; la propagación del libre mercado. El servicio de la deuda siguió siendo una carga para la economía del país.

\subsubsection{Cuarta Etapa (1987-1989)}

A partir de 1986 el gobierno mexicano buscó nuevos instrumentos para aliviar la carga de la deuda externa; los principales fueron la capitalización de pasivos (SWAPS) y el Programa de Conversión de Préstamos en Bonos.

El manejo de dichos instrumentos en el mercado secundario, dio paso a la que es la cuarta fase de la renegociación de la deuda.

Sobre los mercados secundarios, hay que señalar que surgen como una necesidad de la banca acreedora para incrementar el rendimiento de sus activos, así es como aparece la titulación como un mecanismo para reconfigurar su cartera y conseguir la liquidez necesaria para comprometerse en otros negocios o para fortalecer sus reservas.

En palabras de Correa; 
El mercado secundario, se desarrolló introduciendo técnicas e instrumentos financieros - presentes en los mercados financieros de los países desarrollados - a las renegociaciones de la deuda. Básicamente convierte deuda vieja en nueva, deuda mala y de alto riesgo en buena y rentable. En su aplicación en América Latina destaca: 1] la venta de deuda entre los propios bancos; 2] la recompra de deuda por el prestatario; 3] el intercambio de deuda por acciones y 4] la titulación con garantía de los gobiernos [...] (Correa, 1992:105)

"Los SWAPS esencialmente consisten en la compra con descuento por parte de un inversionista privado de los pasivos en moneda extranjera del sector público y de empresas privadas. Con estas operaciones los compradores se convierten en socios de las empresas endeudadas. Las transacciones se efectúan al valor que la deuda del país de que se trata tenga el mercado secundario." (Guillén, 1989: 83)

Para efectuar las operaciones se necesita de la autorización de la Comisión Nacional de Inversiones Extranjera. "Los bancos de depósito, los bancos acreedores internacionales y las Casa de Bolsa actúan como intermediarios entre las empresas endeudadas y los inversionistas potenciales. Entre los inversionistas financieros del país que actuaron como agentes destacan: Bancomer, Banamex, Serfin, Operadora de Bolsa e Inverlat.” (Guillén, 1989:84)

Los swaps no funcionaron como un mecanismo para concluir con el endeudamiento, sino que mas bien fueron promotores de la inversión.

El otro mecanismo, el de conversión de prestamos en bonos, surgió en enero de 1988 a partir de un nuevo programa de renegociación entre el gobierno Mexicano y un banco de New York el Morgan Guaranty Trust.

La propuesta original consistía en convertir 20 mil millones de dólares de la deuda pública mexicana en bonos con plazo de 20 años. La deuda compraría el valor que tiene en el mercado secundario, que en ese entonces se encontraba en aproximadamente el 50 por ciento de su valor nominal, lo que implicaba que México emitiría bonos por 10 mil millones de dólares. Paralelamente el Departamento del Tesoro de Estados Unidos emitiría 
bonos "cupón cero" por 10 mil millones, como garantía de la operación, los cuales serían comprados por México con un solo pago de 2 mil millones que se tomarían de la reserva monetaria. (Guillén, 1989: 87-88)

Este nuevo mecanismo no resolvía los problemas de fondo de la deuda, por lo cual México siguió obligado a pagar el servicio de la deuda por encima de su capacidad real de pago, siendo los principales beneficiados los bancos.

En 1989 se presentó un nuevo plan de renegociación de la deuda, el Plan Brady, éste incorporó las prácticas bancarias previamente instrumentadas en los mercados financieros para el tratamiento de la deuda y que el Banco Mundial venía difundiendo con tanto interés. Propuso como disminución de pasivos el intercambio de deuda con descuento y la participación de las instituciones multilaterales y los gobiernos para ofrecer las garantías necesarias a la titulación, como se vino haciendo meses atrás y de esta manera, incorporó o atendió a la demanda de los prestatarios de responsabilidad compartida. (Correa, 1992: 100)

Este Plan lo mismo que el Baker, antepuso como requisito la aplicación de un programa de ajuste que;

1] Elimine el déficit presupuestal; 2] privatice las empresas estatales (no solo las ineficientes; 3] otorgue mayores incentivos a la inversión nacional y extranjera; 4] libere el comercio exterior, y 5] libere los sistemas financieros. (Correa, 1992: 100)

Al igual que en el Plan Baker y en las renegociaciones anteriores, no se disminuyó la deuda; pero si se sumergió más al país en la liberalización y desregulación de su economía. La titulación de la deuda, así como la diversificación del papel de los agentes financieros afianzaron en el país la formación de un grupo en el poder encabezado por la oligarquía financiera, esto hizo irreversible el hecho de que México se encontraba ya dentro de la financiarización; lo que era importante era la obtención de mayores ganancias y eso era probable dentro del sector financiero.

Respecto a la conformación de un grupo en el poder encabezado por los grandes grupos financieros, como Vidal argumenta; 
La financiarización de la actividad económica, medio que permite a pocos capitales contar con altos niveles de rentabilidad- en un espacio recesivo- y el traslado de cuantiosos recursos al exterior- con una inflación ascendente- continúa lesionando a los capitales que no logran colocarse en los espacios financieros. Diversos capitales medios y pequeños de la industria, el comercio y los servicios son drásticamente reducidos. (Vidal, 1989: 133)

Esta nueva recomposición en los grupos del poder esta sustentada en los grandes cambios que trajo consigo la desregulación y la liberalización del sector financiero durante la década de los ochenta, en las innovaciones en dicho sector. El negocio financiero cambió radicalmente, aparecieron nuevos instrumentos, otros cobran significancia y se incrementó el papel de los intermediarios financieros no bancarios al tiempo que desaparecieron las líneas de especialización institucional.

Correa describe claramente esta situación de la manera siguiente;

Las innovaciones financieras le dieron a los mercados financieros la posibilidad de operar títulos del más diverso orden: vencimiento, rendimiento, denominación monetaria y garantías. Además son fácilmente intercambiables, con lo que los distintos intermediarios financieros pueden configurar y reconfigurar sus carteras rápidamente y acoplarse a diversas expectativas. Así, se acrecentó el papel de los intermediarios financieros no bancarios y se estrecharon más los vínculos entre los distintos tipos de instituciones al ser el crédito bancario un soporte de las operaciones de intercambio de títulos. El volumen de recursos intermediados creció también, con lo que distintos agentes pudieron ver incrementarse sus utilidades. Se desarrollaron los mercados a futuro, los de opciones de divisas y de tasas de interés (swaps). (Correa, 1992: 95)

Hasta aquí el análisis del endeudamiento externo y el proceso de renegociación de la deuda. Los siguientes puntos estarán enfocados en examinar otros hechos sustantivos que se dieron durante la década de los ochenta y principio de los noventa, como fueron la nacionalización 
y la reprivatización de la banca. Estos acontecimientos deben ser estudiados ya que son hechos fundamentales en la transformación de la estructura financiera del país que no deben pasarse por alto.

Pero antes de comenzar con dicho análisis, retomaré otro hecho fundamental para los cambios en la estructura financiera y en la banca. Este es el referente a la conformación de una nueva oligarquía financiera.

El análisis realizado líneas arriba, permite mostrar los cambios que se dieron dentro de los grandes grupos de poder, que se verían beneficiados por la desregulación y liberalización de la economía, en específico del sector financiero, dando paso a la conformación de una nueva oligarquía financiera, como se vera en las siguientes líneas.

\subsection{Sobre la conformación de una nueva oligarquía financiera}

La forma que ha venido adoptando el sistema financiero de México, se ha determinado dadas las condiciones de los sistemas financieros a nivel internacional, que desde décadas atrás mantienen su tendencia a "la universalización y globalización bancaria, entendiendo por universalidad; el cumplimiento de la totalidad de los servicios por una sola entidad bancaria." (Banco de México, 2012: 12)

En México esta tendencia cobró fuerza con la formación de los grupos financieros, estos grupos eran encabezados por un banco de depósito, que conseguía agrupar como filiales, a una hipotecaria, una financiera, un departamento de ahorro y uno de fideicomiso, continuando con la adquisición de una compañía de seguros, un almacén de depósitos y una casa de bolsa, y se podría continuar hasta poder adquirir una filial de otro tipo como empresas del sector industrial y de servicios.

Esta tendencia a la conformación de grupos financieros, se basaba en la tendencia a explotar los beneficios de la unión de diversas especializaciones o giros de los servicios financieros, así como las ventajas operativas y de mercadotecnia que le ofrecía el trabajo integrado. Otra tendencia fue la integración de bancos de depósito. 
Fue hasta 1970, que fue reconocida legalmente la existencia de estos grupos financieros, imponiéndoles la obligación de seguir una política financiera coordinada y de establecer un sistema de garantías recíprocas en caso de la perdida de sus capitales pagados. A pesar de lo nuevo del concepto de grupo financiero y sus obligaciones, para 1974 existían en México 15 grupos financieros, sobresaliendo los encabezados por: Banco Nacional de México, Banco de Londres, Banco Comercial Mexicano, Banco del País, Banco de Industria y de Comercio y Banco internacional.

Este reconocimiento de los grupos financieros, no fue el único suceso importante en el sector bancario durante la década de los setenta. El surgimiento de la banca múltiple también fue una transformación importante de la banca nacional.

Este concepto de banca múltiple, venía incluido en el paquete de reformas económicas instrumentadas por el presidente en turno Luis Echeverría. La adopción de la banca múltiple en el país, fue en tres etapas: (Banco de México, 2012: 14)

- La primera consistió en una reforma legal un tanto limitada, por lo que solo se anunció su implantación en México en 1974

- Después en 1978 se efectuaron una serie de reformas a la Ley Bancaria

- Para concluir en la conformación de los bancos múltiples en 1980

La banca múltiple se definió, como una sociedad autorizada para ejercer las siguientes acciones; depósito, ahorro, intermediación financiera e hipotecaria y operaciones de fideicomiso.

Al adoptarse la banca múltiple en el país, se pensaba que permitiría a los bancos mexicanos una mayor penetración en el mercado financiero internacional, y que sería mucho más eficaz que la banca especializada.

A su surgimiento, se pensó que la banca múltiple sería conformada por la fusión de un banco de depósito, de una financiera y una sociedad hipotecaria ya existente, pero en 1978 con la flexibilidad de las leyes, se permitió el establecimiento de bancos múltiples de nueva creación. 
Los primeros bancos múltiples en crearse fueron:

Multibanco Mercantil de México, Banpacífico, Banca Promex, Banco de Crédito y Servicios y Unibanco (en este caso la sociedad fusionante fue Financiera de Fomento Industrial).

Las grandes instituciones que se constituyeron en bancos múltiples fueron:

Comermex, Banamex, Internacional, Atlántico, Serfin, Bancomer. Seguidos por; Banco

Obrero en 1979, Banco Mexicano-Somex en 1980, Banco Monterrey en 1980 y Banco Aboumrad en 1980.

La existencia de bancos múltiples no implicó la desaparición de grupos financieros, siguieron existiendo.

\subsection{La Nacionalización de la banca.}

Uno de los hechos más importantes para la consolidación de los grupos financieros es la nacionalización de la banca. Ésta fue una expropiación decretada por el presidente José López Portillo que se basó en las excesivas ganancias de lo que era un servicio público concesionado.

Se habían creado monopolios sustentados por los intereses privados de los dueños de bancos, se pretendía terminar con la concentración del crédito entre los sectores más altos de la sociedad y que llegara de manera más equitativa a toda lo sociedad, se buscaba encontrar un salida a la crisis económica agravada por la falta de control del Estado sobre el sistema financiero, así como establecer una calma en la sociedad. (Banco de México, 2010: 16)

Bajo los supuestos anteriores se estableció un control de cambios generalizado, este control de cambios se sustentaba en la austeridad de las políticas económicas aplicadas en la administración anterior y que habían propiciado la fuga de capitales.

El decreto expropiatorio, establecía que se expropiaba a favor de la nación, las instalaciones, edificios, mobiliario, equipo, activos, cajas, sucursales, oficinas, agencias, acciones que tengan en otras empresas y todos los demás muebles e inmuebles de los bancos expropiados. "Lo expropiado fueron los activos, o sea los recursos totales de los 
bancos, que al 30 de junio [...] ascendían a 2 billones 400 mil millones de pesos" (Aguilar, 1989: 34) distribuidos como se muestra en el cuadro 2.

Un detalle importante de esta expropiación fueron las excepciones, quedando fuera las instituciones nacionales de crédito y banca mixta (Banca Somex y el Banco Internacional) que ya eran propiedad del gobierno, el Banco Obrero - que pertenecía al sector laboralademás de Citibank y las oficinas de representación de bancos extranjeros, ya que no eran propiedad de mexicanos.

Cuadro 2. Activos de los bancos expropiados

\begin{tabular}{lc}
\hline \multicolumn{1}{c}{ Banco o grupo bancario } & Millones de pesos \\
\hline Banamex & $666,630.9$ \\
Bancomer & $651,754.50$ \\
Serfín & $276,482.90$ \\
Comermex & $229,992.90$ \\
Atlántico & $69,473.70$ \\
BCH & $56,291.20$ \\
Banpaís & $49,900.00$ \\
Banca Cremi & $43,258.50$ \\
Bancrecer & $40,810.00$ \\
Mercantil de México & $35,730.00$ \\
Confía & $32,741.00$ \\
Otros & $246,156.80$ \\
\hline Total & $2,399,212.40$ \\
\hline \hline
\end{tabular}

Fuente: Aguilar, Alonso (1989). La Nacionalización de la

Banca la crisis y los monopolios, pág. 35

La expropiación estaba hecha, y entraron en vigor nuevas medidas de política bancaria, que estuvieron vigentes hasta diciembre de 1982, estas medidas se enfocaban a la estructura de las tasas de interés y respecto a los tipos de cambio con que operaban los bancos.

Respecto a las tasas de interés (Banco de México, 2012: 17):

1. Las tasas sobre nuevos depósitos disminuirían dos puntos porcentuales por semana durante cinco semanas

2. El rendimiento anual para los depósitos de ahorro se elevarían de 4 a $20 \%$ 
3. Las tasas aplicables a los créditos para empresas productivas se reducirían en cinco puntos

4. Las tasas aplicables a los créditos para la vivienda de interés social se reducirían hasta 23 puntos porcentuales para unificarlos en 11 por ciento

Respecto a los créditos y depósitos denominados en moneda extranjera:

- A los créditos se les aplicaría un tipo de cambio preferencial de 50 pesos por dólar

- A los depósitos se les aplicaría el tipo de cambio ordinario de 70 pesos por dólar.

¿Que tan favorable fue la expropiación de la banca en México?, sería una cuestión de enfoques y ha sido el centro de discusión en los más fuertes debates en la historia del país. La administración entrante tenía que concluir con el proceso expropiatorio iniciado por José López Portillo, así pues, se exigía al nuevo gobierno del presidente De La Madrid, la indemnización de los accionistas bancarios que habían sido expropiados, la redefinición del banco como institución y una tarea muy importante era llevar a cabo la reestructuración del sistema bancario, buscando una eficiencia del sistema, conservando la mayor rentabilidad y competencia posibles. Entonces, la tarea del nuevo gobierno no era nada sencilla, había que enfrentarse a una convertida banca en manos del sector público, así como cubrir las indemnizaciones de los bancos expropiados.

Pero ¿cómo saber cual es el valor de un banco?. La medida que adoptó el gobierno fue la de tomar en cuenta la capacidad de los bancos para producir ganancias en el futuro, es decir, su valor económico. La indemnización concluyó a inicios del año de 1985, absorbiendo casi un 70\% del total del monto a indemnizar, los bancos más grandes del país (Banamex y Bancomer).

Ahora bien, el presidente De la Madrid, ejecutó una medida legal para reorganizar el curso a seguir del sistema financiero en su totalidad. Tratando de limitar las actividades de los bancos en propiedad de la nación con el resto del sistema financiero, legalizó la privatización de las filiales bancarias. 
Esta privatización de las filiales se sustentaba en el fomento de una economía mixta donde el sector privado se viera incentivado a invertir en este sector, así como restablecer el orden entre las actividades distintas a las bancarias entre sector privado y sector público.

La medida anterior fomentó la conocida como banca paralela, en la cual a las casas de bolsa se les delegaba por completo el manejo de los títulos de la deuda pública, limitando a la banca en su participación en la llamada captación no tradicional.

Este proceso de restructuración de la banca no fue del todo desfavorable, según cifras del propio Banco de México, en el periodo de 1982 a 1988 la captación bancaria creció en términos reales 4.3 por ciento promedio anual, el ahorro financiero que fue de 30 por ciento con respecto al PIB en 1982, se incrementó a 40 por ciento en 1988. (Banco de México, 2012: 19)

Bajo el mandato del presidente Miguel de la Madrid se puso en marcha el Programa Inmediato de Reordenación Económica (PIRE), estaba orientado a combatir la inflación, la inestabilidad cambiaria y la escasez de divisas, el abasto y la planta productiva y recuperar las bases para el desarrollo sostenido. Las modificaciones legales se empezaron a operar en 1983, destacando la Ley Reglamentaria del Servicio Público de Banca y Crédito, que señalaba la conversión de las instituciones nacionalizadas por su antecesor y las instituciones mixtas de crédito, en Sociedades Nacionales de Crédito, estas fueron instituciones de derecho público, de duración indefinida.

En 1984 la Secretaría de Hacienda y Crédito Público (SHCP) informó que las empresas que la banca poseía en el momento de su nacionalización serían vendidas a los antiguos accionistas de los bancos.

Fue en este año que el Ejecutivo Federal envió al Congreso diversas propuestas de ley que modificaban al Sistema Financiero Mexicano, destacando las siguientes: (Ortega y Villegas, 1995: 45)

a) La Ley Reglamentaria del Servicio Público de Banca y Crédito, que separaba a las sociedades nacionales de crédito en instituciones de banca múltiple e instituciones de banca de desarrollo. 
b) La Ley Orgánica del Banco de México resaltaba la facultad que le da el Ejecutivo Federal para decidir mediante decretos sobre el control de cambios.

c) La Ley General de Organizaciones y Actividades Auxiliares de Crédito, prohibía a las organizaciones auxiliares de crédito seguir políticas de grupo y permitía a los bancos participar en el capital de almacenes generales de depósito o de arrendadoras financieras. Prohibía la regulación y autorización de las casas de cambio como actividad auxiliar del crédito para realizar las operaciones de compra, venta y cambio de divisas en forma cotidiana y profesional.

Para 1988 se eliminaron restricciones a la banca en tres ámbitos: (Ortega y Villegas, 1995: 46)

1. En lo referente a la limitación de los montos de emisión de instrumentos a tasa de interés libre, es decir, los bancos podrían emitir aceptaciones bancarias más libremente. Se sustituyó el encaje legal.

2. Los bancos podrían ofrecer libremente sus tasas de interés, ya no existía la fijación de topes.

3. Se eliminaron las restricciones a las actividades a las que se canalizarían sus recursos.

En el año de 1989, prácticamente se eliminaron los cajones de inversión bancarios y los topes de aceptación, al existir tasas de interés liberadas, ya no se giraría en torno de la tasa de Costo Promedio Porcentual (CPP), ya que los bancos podrían ofrecer tasas más competitivas con base a su productividad.

Es en 1989 cuando el sistema financiero comienza a caracterizarse por la desregulación, los cambios en el marco jurídico, las modificaciones en el régimen de propiedad de la banca y la apertura financiera.

Es en este punto de la historia de donde devienen los hechos que le darán su forma actual al sistema financiero mexicano. Es el despegue de un nuevo gobierno, que durante su sexenio ejecutó medidas económicas, políticas y sociales que tendrían implicaciones sistémicas. México venía de un intenso proceso de endeudamiento no solo público sino privado, con el 
exterior que le habría llevado a tener altos niveles deficitarios, se adquiría deuda para pagar otra deuda. La crisis de la deuda, dejó un México sensible, vulnerable a los envistes de las encomiendas globalizadoras, de las "recomendaciones" del FMI y del Consenso de Washington, era el momento adecuado para enlistar a México al proceso neoliberal que se encontraba más que presente a nivel internacional, encabezado por los Estados Unidos.

\subsection{La reprivatización de la banca}

La época transcurrida a finales de los años ochenta y principios de los noventa del siglo pasado, marcaron de manera crucial al sistema financiero mexicano. Se hicieron cambios a las leyes para la transformación del sistema bancario que había sido nacionalizado por el gobierno del López Portillo. Las modificaciones ejecutadas por el gobierno de Carlos Salinas de Gortari, tenían un claro enfoque neoliberalizador y globalizador, en este afán por convertir al sistema bancario del país, en un sistema universal y que se integrase al contexto globalizador que prometía a las naciones del tercer mundo, ser parte del desarrollo. Se promulgaron nuevas leyes en beneficio del capital privado y se permitió la participación; aunque hasta cierto punto restringida, de capital foráneo, en la adquisición de empresas financieras, así como en la formación y concentración del capital y también en la creación de nuevos grupos financieros que a lo largo del proceso formarían una nueva oligarquía financiera.

Las reformas dieron pie a un profundo cambio en la distribución y apropiación de la riqueza por parte de los grandes grupos capitalistas tanto nacionales como extranjeros, que se conformaron tras dichas reformas.

Las modificaciones a las leyes promovían una integración de los sectores productivos y financieros mediante la privatización, permitiendo a los grandes tenedores de capital industrial adquirir cierto porcentaje de acciones tipo "B" o Certificados de Participación.

Con la privatización surgieron nuevas formas de centralización patrimonial; inversionistas financieros e inversionistas de control y gestión, con esto se dio paso a una nueva integración de los conglomerados industriales, comerciales y financieros, generando así una forma distinta de estructura oligárquica mucho más fuerte y concentrada. 
El proceso de reprivatización de la banca, siguió un camino que comenzó en diciembre de 1988 con la publicación del Plan Nacional de Desarrollo 1988-1994, en el que se tenía como principal propósito la modernización de la economía mexicana.

Siguiendo una cronología de los hechos, la reprivatización siguió el siguiente camino:

En diciembre de 1989, el paquete financiero

Enero 3 de 1990, el Programa para el financiamiento del Desarrollo 1990-1994

El 23 de enero de 1990, la iniciativa presidencial para la modificación de los artículos 28 y 123 de la Constitución que tenía como objetivo ampliar la participación de los sectores privado y social en el capital de los bancos

El 27 de junio de 1990, la publicación de las modificaciones constitucionales de los artículos señalados, en el Diario Oficial de la Federación

El 28 de junio de 1990, las iniciativas de la Ley de Instituciones de Crédito, la Ley para Regular a las Agrupaciones Financieras y un decreto por el cual se modificaban y adicionaban diversas disposiciones de la Ley del Mercado de Valores.

Con la Ley de Instituciones de Crédito el gobierno buscaba restablecer el régimen mixto de la banca, señalándose que el servicio de banca y crédito sólo podrá ser prestado por este tipo de instituciones y que éstas pueden ser de banca múltiple o de desarrollo, también define sus características, su forma de organización y los mecanismos de protección de los intereses del público ahorrador.

La Ley para regular las Agrupaciones Financieras; permitía la formación de grupos a través de empresas controladoras, de bancos múltiples o de casas de bolsa y así fomentar la conformación de grupos más fuertes y diversificados capaces de responder ante las necesidades del país. Esta ley se presentaba como un antecedente de lo que podría ser la banca universal en el país.

Dos fueron las razones principales para la ejecución de la Ley para Regular las Agrupaciones Financieras: 1) se consideraba como conveniente la inclusión a las instituciones de banca múltiple en tales grupos, con el fin de proteger los intereses del público y 2) establecer limitaciones para evitar piramidaciones indeseables de capital, es 
decir, "cuando se habla en la ley de evitar la piramidación se refiere a los holdings financieros. (Morera, 2002: 111).

Para lo anterior se establecía en la ley antes mencionada; que el control de las asambleas generales de accionistas y de la administración de todos los integrantes de cada grupo debería tenerlos la misma sociedad anónima controladora y las acciones serie "A" deberían representar 51\% del capital pagado por la sociedad y solo podrían ser adquiridas por personas físicas mexicanas, extranjeros en calidad de inmigrantes en el país y por los fondos de protección referidos en la Ley del Mercado de valores.

El 18 de julio de 1990, se realizó la publicación de las leyes antes mencionadas; en el Diario Oficial de la Federación, cambiando así el régimen de derecho público por el de derecho privado en las leyes bancarias.

El 4 de diciembre de 1990, se estableció el acuerdo en el que se asientan las bases para la desincorporación de las sociedades nacionales de crédito.

Para el 25 de diciembre de 1990 se publicaron en el Diario Oficial de la Federación las bases generales o principios de la desincorporación de las Instituciones de Banca Múltiple, propiedad del Gobierno Federal: (Villegas y Ortega, 2002: 44)

- Conformar un sistema financiero mas eficiente y competitivo;

- Garantizar una participación diversificada y plural en el capital;

- Vincular de la aptitud y calidad moral de la administración de los bancos con un adecuado nivel de capitalización;

- Asegurar que la banca mexicana sea controlada por mexicanos;

- Buscar la descentralización y el arraigo regional de las instituciones

- Buscar la obtención de un precio justo por las instituciones

- Lograr la conformación de un sistema financiero balanceado y,

- Propiciar las sanas practicas financieras y bancarias

El proceso mencionado culminó en la reprivatización bancaria. A continuación en el cuadro 3 se muestra la venta de bancos nacionalizados, que se llevó a cabo durante los primero años de la década de los noventa. 
Cuadro 3. La venta de bancos

\begin{tabular}{|c|c|}
\hline BANCO VENDIDO & COMPRADOR \\
\hline $\begin{array}{l}\text { Multibanco Mercantil de } \\
\text { México }\end{array}$ & $\begin{array}{l}\text { Su venta se concretó el } 11 \text { de junio de } 1991 \text { y fue realizada por } \\
\text { Grupo Financiero Probursa. Con esto se conformó el primer grupo } \\
\text { financiero de México; integrado por Casa de Bolsa Probursa, } \\
\text { Factoring Profacmex, Almacenadora Probursa y Casa de Cambio } \\
\text { Probursa. }\end{array}$ \\
\hline Banpaís & $\begin{array}{l}\text { Fue adquirido por Grupo Financiero Mexival, el } 17 \text { de junio de } \\
\text { 1991. Este grupo financiero quedo conformado por; Casa de Bolsa } \\
\text { Mexival, Seguros Constitución, Arrendadora Plus, Casa de } \\
\text { Cambio Divimex y Banpaís }\end{array}$ \\
\hline Banca Cremi & $\begin{array}{l}\text { Grupo Multivia lo adquirió el } 24 \text { de junio de 1991. Este grupo } \\
\text { quedó constituido por Casa de Bolsa Multivalores, Multivalores } \\
\text { Casa de Cambio y Banca Cremi. }\end{array}$ \\
\hline Banamex & $\begin{array}{l}\text { Se vendió el } 27 \text { de agosto de } 1991 \text { a Acciones y Valores Casa de } \\
\text { Bolsa. Se creó el Grupo Financiero Banamex-Accival formado } \\
\text { por Acciones y Valores Casa de Bolsa, Banamex y AVM Casa de } \\
\text { Cambio. }\end{array}$ \\
\hline Bancomer & $\begin{array}{l}\text { Fue vendido al Grupo Valores Monterrey (Vamsa) el } 27 \text { de } \\
\text { octubre de 1991. Vamsa quedó conformado por Seguros } \\
\text { Monterrey, Arrendadora Monterrey, Fianzas Monterrey, } \\
\text { Almacenadora Monterrey y Acciones Bursátiles. }\end{array}$ \\
\hline $\begin{array}{l}\text { Banco de Cédulas } \\
\text { Hipotecarias }(\mathrm{BCH})\end{array}$ & $\begin{array}{l}\text { Fue adquirido por un grupo de agroindustriales del sureste de } \\
\text { México, el } 10 \text { de noviembre de } 1991 \text {. }\end{array}$ \\
\hline Serfin & $\begin{array}{l}\text { Grupo OBSA lo compró el } 26 \text { de enero de } 1992 \text { y se conformó el } \\
\text { grupo financiero Serfin que estaba integrado por Operadora de } \\
\text { Bolsa, Casa de Bolsa, Factor OBSA y Banca Serfin. }\end{array}$ \\
\hline Multibanco Comermex & $\begin{array}{l}\text { Fue adquirido por Grupo Financiero Inverlat y otros } 4000 \\
\text { accionistas el } 10 \text { de febrero de 1992. Grupo Financiero Inverlat } \\
\text { quedó integrado por Casa de Bolsa Inverlat, Arrendadora Inverlat } \\
\text { y Comermex. }\end{array}$ \\
\hline Banco Mexicano Somex & $\begin{array}{l}\text { Se vendió a un grupo de inversionistas el } 6 \text { de marzo de 1992, } \\
\text { posteriormente se formó el grupo financiero Inverméxico }\end{array}$ \\
\hline Banco del Atlántico & $\begin{array}{l}\text { La Casa de Bolsa Grupo Bursátil Mexicano (GBM) y un grupo de } \\
\text { inversionistas, adquirieron } 56 \text { millones de acciones de Banco del } \\
\text { Atlántico el } 29 \text { de marzo de } 1992 \text {. Tras esta adquisición GBM se } \\
\text { convirtió en el Grupo Financiero GBM Atlántico y estaba } \\
\text { formado por Casa de Bolsa GBM, Arrendadora Atlántico, Factor } \\
\text { Atlántico y Casa de Cambio GBM Atlántico. }\end{array}$ \\
\hline Banca Promex & $\begin{array}{l}\text { E1 } 5 \text { de abril de } 1992 \text { Casa de Bolsa Finamex adquirió } 250767 \\
\text { millones de acciones de este banco. Después de la compra se } \\
\text { conformó el Grupo Financiero Finamex, integrado por Casa de } \\
\text { Bolsa Finamex, Banca Promex, Arrendadora Finamex, Factoraje }\end{array}$ \\
\hline
\end{tabular}




\begin{tabular}{|c|c|}
\hline & Finamex y Promotora de Cambios y Divisas Casa de Cambio \\
\hline Bonoro & $\begin{array}{l}\text { Este banco que fuese resultado de la fusión de Banco del Noreste, } \\
\text { Banco Occidental, Banco Provincial de Sinaloa y Unibanco, fue } \\
\text { comprado por Casa de Bolsa Estratégica y Bursátil y } 500 \\
\text { inversionistas, el } 12 \text { de abril de } 1992 \text {. }\end{array}$ \\
\hline $\begin{array}{l}\text { Banco Mercantil del Norte } \\
\text { (Banorte) }\end{array}$ & $\begin{array}{l}\text { Banorte, resultado de la fusión de Banco Mercantil de Monterrey } \\
\text { y Banco Regional del Norte, fue adquirido el } 14 \text { de junio de } 1992 \\
\text { por un grupo de inversionista del noreste de México, encabezados } \\
\text { por Roberto González Barrera, José Antonio González y Federico } \\
\text { Graf Campos. }\end{array}$ \\
\hline Banco Internacional & $\begin{array}{l}\text { Grupo Financiero Prime, conformado por Casa de Bolsa Prime, } \\
\text { Arrendadora Prime, Casa de Cambio Prime, Almacenadora Prime, } \\
\text { Seguros Interamericana y Fianzas de México, compró Banco } \\
\text { Internacional, el } 28 \text { de junio de } 1992 \text {. }\end{array}$ \\
\hline Banco del Centro (Bancen) & $\begin{array}{l}\text { El } 6 \text { de julio de } 1994 \text { Grupo Financiero Multivalores adquirió } \\
\text { Bancen. Este Grupo quedó conformado por Bancen, Casa de } \\
\text { Bolsa Multiva, Arrendadora Multiva, Factoraje Multiva y Casa de } \\
\text { Cambio Americam. }\end{array}$ \\
\hline Banca Confía & $\begin{array}{l}\text { Fue adquirido por Grupo Ábaco el } 4 \text { de agosto de 1992. El Grupo } \\
\text { Financiero Ábaco quedó compuesto por Ábaco Casa de Bolsa, } \\
\text { ABA Divisas, ABA Factor, Arrenda y Seguros del País. }\end{array}$ \\
\hline Banco de Oriente & $\begin{array}{l}\text { Lo adquirió Grupo Margen que estaba conformado por } \\
\text { Afianzadora Margen, Arrendadora Financiera Margen, C.C } \\
\text { Cambio del Valle y Factor Margen; el } 11 \text { de agosto de } 1992 .\end{array}$ \\
\hline Bancrecer & $\begin{array}{l}\text { Se vendió el } 18 \text { de agosto de 1994, luego de su venta los } \\
\text { accionista crearon el Grupo Financiero Bancrecer que estaba } \\
\text { formado por el banco, Casa de Cambio Bancrecer, Arrendadora } \\
\text { Financiera Bancrecer y Factoraje Bancrecer. }\end{array}$ \\
\hline
\end{tabular}

Fuente: Elaboración propia con información de Villegas y Ortega (2002).

"La banca se vendió al sector privado a un precio promedio equivalente a 3.068 veces el capital contable y 14.75 veces las utilidades conocidas de los últimos 12 meses" (Villegas y Ortega, 2002: 49). A lo largo de la historia siguiente a la reprivatización, se ha criticado el precio tan bajo al que fue vendida la banca mexicana, ya que se puede decir que por el precio pagado por la banca nacional, no se tomaron en cuenta las perspectivas de generación de utilidades.

Las consecuencias de la reprivatización de la banca, se vieron reflejadas de manera inmediata, si bien es cierto que el crecimiento económico del país tuvo un incremento 
durante la década de los noventa, éste disminuyó por el gran flujo de inversión especulativa, patrimonial y consumista, que se tradujo en un intenso consumo de las capas altas y una fuerte inversión financiera y especulativa nacional e internacional.

Los costos consecuencia de las reformas económicas, se han transmitido a la mayoría de la población, bajo varios mecanismos de tipo político, económico, fiscal etcétera.

Las consecuencias han generado una polarización marcada de la sociedad, una apertura indiscriminada hacia el exterior, que en la actualidad solo ha dejado reminiscencias de lo que fuese una banca mexicana. La inserción del sistema financiero de México en el mercado global de capitales, lo ha dejado a expensas de la injerencia de países extranjeros en la toma de decisiones. El sistema financiero nacional ha tomado la forma que le han dictado países como Estados Unidos y España principalmente, en los que se encuentran las matrices de los principales propietarios de la banca en México.

\section{CAPITULO 3. DESREGULACIÓN Y EXTRANJERIZACIÓN DE LA BANCA DURANTE LA DÉCADA DE LOS NOVENTA}


Éste capítulo tiene como objetivo estudiar los sucesos que modificaron el papel de la banca comercial durante la década de los noventa como: la firma del TLCAN, la crisis de 19941995 y el rescate bancario. Se examinan de manera detallada los cambios a la ley bancaria que beneficiaron a los grupos extranjeros que posteriormente pudieron apropiarse casi en su totalidad del sector bancario, profundizándose la financiarización y desregulación del sector financiero. También se analiza el proceso de gestación y afianzamiento de una nueva oligarquía financiera en el país, como una de las consecuencias de los hechos antes mencionados.

\subsection{El concepto de la Desregulación Financiera}

En esta investigación se han utilizado algunos términos y se ha insistido en su análisis, ejemplo de ello es el concepto de la financiarización que se estudió en el capítulo anterior, al considerar fundamental su comprensión. En este capítulo se dará la definición de otro concepto igualmente sustantivo para la investigación; el de la desregulación financiera, ya que es entorno a ésta que giran la hipótesis e ideas principales de este trabajo.

\section{Así, para Eugenia Correa:}

La desregulación [...] se conceptúa como un paulatino o parcial alejamiento de las autoridades financieras respecto de los intermediarios y de su quehacer. Podría entenderse en el sentido de suavizar las normas y las leyes de control, dotando de mayor libertad a los intermediarios (Correa: 1998, 138)

Es la misma autora quien explica los elementos más importantes de la desregulación de los mercados financieros (Correa: 1998, 147-148)

1. Desregulación de tasas de interés. Se han quitado las reglamentaciones que imponían techos sobre éstas, aunque las tasas de descuento de los títulos gubernamentales continúan teniendo un papel importante en los mercados, propiamente como tasas de piso.

2. Se han simplificado los controles de crédito, de inversión y de depósitos obligatorios, cuando no abolido completamente. 
3. Ha disminuido el número de intermediarios financieros y ha avanzado la concentración del mercado en un número menor de éstos.

4. Se ha multiplicado el número de instrumentos financieros con reglas mínimas respecto de su creación, operatoria y expresión en los balances de las instituciones. Sin embargo, dichas reglas varían considerablemente de un mercado a otro.

5. [...] han sido removidos muchos de los obstáculos que impedían la expansión local de los intermediarios extranjeros. Sin embargo dicha remoción en los países desarrollados se ha venido efectuando por medio de acuerdos regionales como el TLC y UE. En esta expansión de los intermediarios por diversos mercados, la aplicación de la informática y de las telecomunicaciones han sido elementos dinamizadores.

Es importante tener claro el significado de la desregulación financiera dados sus alcances en el sector bancario del país y en particular durante el periodo que se analiza.

En los párrafos que a continuación se presentan, se estudian los acontecimientos ocurridos a lo largo de la década de los noventa del siglo pasado, todos ellos bajo el contexto de la desregulación financiera descrita líneas arriba.

\subsection{El nuevo orden mundial}

Hacia la década de los ochenta del siglo pasado era un hecho que a nivel mundial se vivía una transición hacia un nuevo orden económico conocido como neoliberalismo, impulsado por las potencias económicas del mundo principalmente por los Estados Unidos, quien se ocuparía de llevar este régimen hacia los países denominados como subdesarrollados o del tercer mundo o de la periferia.

Un hecho esencial para explicar la inserción de México al neoliberalismo, es el proceso desregulador y de extranjerización del sector financiero, en específico del sector bancario, iniciado a finales de la década de los ochenta con la reprivatización de la banca.

Debo señalar a manera de paréntesis, que en el capítulo anterior se describió la venta de 18 bancos de los cuales 13 se conformarían en grupos financieros, pero algo que es importante 
mencionar son los ingresos que el gobierno obtuvo por la privatización bancaria. "Esta venta le generó recursos nominales al gobierno federal por más de 37 billones de pesos" (Rogozinsky (1993), citado por Vidal, 2002: 19).

Cuadro 4. Ingresos por la privatización bancaria

\begin{tabular}{lc}
\hline \multicolumn{1}{c}{ Nombre del banco } & Porcentajes \\
\hline Banco Nacional de México, S.A. & 25.7 \\
Banca Serfin, S.A. & 7.5 \\
Bancomer, S.A. & 22.6 \\
Banca Promex, S.A. & 2.8 \\
Banco BCH, S.A. & 2.3 \\
Multibanco Mercantil de México, S.A. & 1.6 \\
Banco de Oriente, S.A. & 0.6 \\
Banca Cremi, S.A. & 2 \\
Banco Mercantil del Norte, S.A. & 4.7 \\
Banpaís, S.A. & 1.4 \\
Banco del Centro, S.A. & 2.3 \\
Banco de Crédito y Servicio, S.A. & 1.1 \\
Banoro, S.A. & 3 \\
Banco Internacional, S.A. & 3.9 \\
Banco del Atlántico, S.A. & 3.9 \\
Banco Mexicano Somex, S.A. & 4.9 \\
Multibanco Comermex, S.A. & 7.1 \\
Banca Confia, S.A. & 2.3 \\
\hline \hline Fuente: Vidal, Gregoio (2002). 'Bancos, & \\
\hline
\end{tabular}

Fuente: Vidal, Gregorio (2002). "Bancos, fortunas y poder: una lectura de la economía en el México del 2000”.

En el cuadro 4 notamos que sumando los ingresos obtenidos por la venta de Banamex y Bancomer se obtuvo el mayor monto, por $48.3 \%$ del total, esto da muestra del peso que tenían dichas instituciones en el sistema bancario del país. 
La tercera venta más importante fue la de Serfin, seguida de Multibanco Comermex que sumadas hacen un total de $14.6 \%$ de los ingresos generados por la privatización. (Véase cuadro 4.)

Lo que muestran las cifras de las ventas de estos bancos, es una clara concentración en un número reducido de instituciones y la importancia que tenían en ese momento y que se fortalecería al paso de el tiempo, en la participación en el sector bancario del país.

Continuando con el tema de la incursión del país al nuevo orden mundial, ésta se sustento en una serie de reformas encabezadas por el FMI y el Banco Mundial en lo que sería conocido como el Washington Concensus. Dicha reforma implicó:

- la apertura de la cuenta de capital;

- la eliminación de los depósitos obligatorios de los bancos en el banco central;

- la prohibición del financiamiento del déficit público por el banco central;

- eliminación de los cajones de descuento y crédito dirigido a determinados sectores y los controles sobre tasas de interés;

- desaparición de las actividades de primer piso de la banca pública;

- cambios legislativos para aceptar la participación extranjera accionaria en banca

- la privatización acelerada de los bancos nacionalizados en 1982.

Así bajo la instauración del nuevo orden y con el nuevo gobierno que tenía al frente a Carlos Salinas De Gortari, se gestaba la firma de un acuerdo comercial entre los países de América del Norte (Estados Unidos, Canadá y México) que sería llamado; Tratado de Libre Comercio de América del Norte (TLCAN).

Este acuerdo era la reacción a la profunda crisis global que se había desatado en la de década de los ochenta, o por lo menos eso decían sus defensores.

En palabras del secretario de Comercio Dr. Jaime Serra Puche, responsable del proceso de negociación del TLCAN, "éste le asegura a México [...] un apoyo importante para la estabilidad macroeconómica [...] [léase tipo de cambio] [...], al permitir que el arbitraje 
internacional incida más efectivamente en la formación de precios de los servicios financieros nacionales" (Presentación del secretario de Comercio ante la Comisión de Comercio de la Cámara de Senadores, 12 de agosto de 1992, Citado en Correa, 1995: 311)

Aunque otra lectura de este acuerdo es que el TLCAN, reforzaba la entrada de México al nuevo orden, por medio del libre comercio, la desregulación, la privatización, la estabilización y el ajuste estructural, siendo estos sus principales paradigmas.

Las implicaciones que ha tenido para el país el TLCAN, no han sido las esperadas por los que fuesen sus impulsores, se decía que su entrada en vigor destacaría la especialización, la eficiencia, se incrementarían los ingresos, se mejoraría la competencia, se incrementaría el empleo y las tasas de crecimiento para los tres países; la realidad se ha mostrado muy diferente.

El TLCAN le permitió a Estados Unidos fortalecer su posición comercial y económica con los países vecinos, aunque los convenios establecidos no eran los mismos para cada caso en particular, ya que al firmarse el tratado existían cláusulas que solo aplicaban para Canadá y otras exclusivas para su trato con México. Esto le permitió a Estados Unidos crear relaciones desiguales con cada país, es decir, la relación con México al concretarse el Tratado profundizó el papel del país como principal exportador de ciertos productos, así como la implantación de un mayor número de empresas transnacionales norteamericanas y que con su establecimiento no han significado necesariamente un beneficio en el desarrollo y el crecimiento económico de México, ya que sus ganancias siempre retornan a su país de origen. Al respecto Vidal afirma:

La firma de acuerdos [...] tan sólo han permitido que se afiance la relación con Estados Unidos. Por lo que toca al sector externo es una vinculación observable en un reducido grupo de actividades económicas, mientras que existe una ampliación de los intereses de empresas estadounidenses en el país. (Vidal, 2008: 332) 
En este contexto las pequeñas empresas nacionales al resultar poco competitivas ante la gran ET fueron absorbidas o desaparecidas, surgiendo así fenómenos como la fusión y la adquisición de empresas.

Si bien es cierto que para México significó la entrada de capitales que se habían fugado durante la crisis de la deuda, también significó la perdida de empresas y ganancias en manos de capital nacional. La época de los noventa estuvo plagada de ventas y fusiones en el sistema bancario, pero el TLCAN implicó una fuerte entrada de Inversión Extranjera colocada principalmente en los mercados bursátiles y en deuda pública, para 1992 el saldo de IE en la bolsa era de algo más de 27 mil millones de dólares (Vidal, 1995: 173).

Aunque algo que fuese un hecho es que, las disparidades entre los tres países que integrantes del TLCAN, no le han permitido a México alcanzar, ni por lo menos acercarse, al crecimiento de los vecinos del norte, sino que se han incrementado dichas disparidades, hecho que se ve reflejado en la baja competitividad de nuestro país a nivel mundial, el incremento de la pobreza, la fuerte concentración del ingreso y los bajos salarios que existen en nuestro país.

En este trabajo no se abarcarán todos los puntos que se firmaron en el TLCAN, sino que nos concentraremos en las implicaciones para el sistema financiero (en particular la banca) del país. Esto es trascendental para esta investigación, ya que sin un análisis de los hechos que resultaron de dicho acuerdo no se podría comprender la conformación ni el poder que fue tomando la oligarquía financiera en el país, que sería una consecuencia de la desregulación que devino de este tratado; así como la extranjerización del sector bancario y también nos ayudará a entender otro hecho fundamental en la historia económica del país: la crisis bancaria de 1994-1995.

\subsection{TLCAN y la banca comercial en México}

Entendiendo lo anterior, se comenzará con el análisis de las implicaciones del TLCAN al sector financiero del país, en particular a la banca. Destacando que con la firma de este acuerdo se presentó la desregulación financiera en México a su máxima expresión dadas las características mencionadas anteriormente. 
Las transformaciones de los sistemas financieros nacionales de los países integrantes, así como las estipulaciones del TLCAN estaban marcadas por una vocación de crear un espacio sin fronteras físicas y barreras financieras (libre movimiento de capitales, libre establecimiento bancario etc.) Las empresas financieras tenían ante sí tres importantes desafíos; como explica Alicia Girón (Girón, 1995: 254):

a) el mercado único;

b) los cambios en materia jurídica de la legislación bancaria para lograr una mayor liberalización en los servicios financieros;

c) la tendencia a la banca universal en Canadá y México, opuesta a la envejecida estructura de la banca especializada de Estados Unidos.

Para algunos autores como Correa (2010) y Soto (2009), los cambios ocurridos permiten hablar de una globalización financiera que trajo consigo cambios fundamentales en el papel de la banca en México, es decir, el objetivo funcional que tenían los bancos hasta antes de la crisis de 1982 - otorgamiento del crédito hacia las empresas para que éstas realizaran sus actividades productivas - pasó a un sistema dedicado a otros tipos de actividades financieras de mayor riesgo como son las operaciones en el mercado de derivados (Soto, 2009: 116).

Dicha globalización financiera “[...] especialmente en los noventa, implicó para los bancos mexicanos una presión competitiva enorme y distinta, puesto que sus actividades de intermediación en moneda extranjera dependían del estado de liquidez en que se encontraba el mercado financiero internacional, específicamente del volumen y costos de la oferta de fondos procedente de sus propios competidores.” (Correa, Ferreiro y Gómez, 2010: 150).

Respecto a la modificación de las funciones de la banca, Alicia Girón advierte:

[...] la actividad bancaria abarca ahora áreas no tradicionales y coincide con el desarrollo extraordinario de otras instituciones financieras y no financieras, las cuáles han venido proveyendo servicios de tipo bancario y formando bancos que no son bancos [...] el surgimiento de nuevos intermediarios financieros asociados a una diversificación de carteras de derivados determinados por los flujos de capital hacen 
más difícil no sólo la intermediación bancaria tradicional sino el mantenimiento de la estabilidad del sistema financiero internacional (Girón, 2002: 48)

Es importante mencionar que el proceso de desintermediación inducido por la competencia ha provocado una tendencia a la

disminución de operaciones tradicionales que integran los balances de los bancos, los recortes de costos y la consolidación de las operaciones bancarias mayoristas, así como a la expansión de las actividades bancarias que no figuran en sus balance. Habida cuenta de la interrumpida pérdida de la participación de los bancos en los pasivos de las sociedades anónimas, se ha elevado rápidamente la de los fondos de inversión y del papel comercial (FMI, citado por Girón, 2002: 49).

Y más adelante Girón afirma que “después del proceso de privatización y liberalización de los ochenta el sector productivo se contrajo y las instituciones bancarias nacionales buscaron acrecentar sus ganancias, con las operaciones fuera de balance (gestión de derivados, opciones y futuros financieros)" (Girón, 2002: 50)

La banca comercial para enfrentar los cambios que traería el Tratado de Libre Comercio, tuvo que diversificar los servicios que ofrecía para resultar mucho mas rentable que las nuevas instancias del extranjero que funcionarían en nuestro país, se desarrollarían operaciones tales como; comercio de divisas, acuerdos sobre tasas a término, operaciones a futuro, prestamos con resguardos de valores que dejan claro las modificaciones del negocio bancario.

La banca comercial incrementó su papel como intermediario, siendo el elemento central para asegurar lo anterior la creación y la expansión de nuevos mecanismos de financiamiento mucho más ligados a la emisión de todo tipo de títulos y valores respaldados con deuda, perjudicando los financiamientos tradicionales.

Se puede señalar entonces, un cambio en las formas y mecanismos de financiamiento, es decir, se reduce le financiamiento vía banca comercial, ya que la titularización de los 
mercados implicaría que los agentes buscaran financiamiento de liquidez en los mercados de valores.

Uno de los mayores retos de la banca comercial era el demostrar su capacidad para adaptarse al surgimiento de una nueva forma de finanzas, mucho más ligada a la emisión de valores negociables respaldados por deuda que a los créditos bancarios basados en la relación depósito préstamo. Para lograr dicha adaptación la banca mexicana tuvo como principales estrategias: la especialización de sus servicios. Aunque algo de gran importancia sería consolidar sus posiciones en su propio mercado nacional logrando con esto, ampliar sus servicios y racionalizar sus costos, implicando fusiones y adquisiciones estratégicas.

La libre movilidad de servicios extranjeros en el país, representó una fuerte competencia para la cual la banca nacional no se encontraba preparada para enfrentar, ya que se encontraba en un momento de ajustes y su fragilidad implicó que los capitales extranjeros aprovecharan dicha fragilidad para intervenir en un mercado bancario ya para ese entonces muy manoseado.

Las implicaciones del TLCAN para el sistema bancario mexicano, más que beneficiarse de un acuerdo trilateral que aseguraba un desarrollo equitativo de los sistemas financieros, sería absorbido casi en su totalidad por empresas del exterior.

La liberalización del sistema financiero mereció artículos con minuciosas especificaciones que dejaban a la vista una liberalización con diversas excepciones, en este sentido Armendáriz y Mijangos afirman:

[...] implicaría el libre establecimiento comercial de bancos de otros países para que prestasen sus servicios en el país anfitrión y la libre prestación del servicio sin necesidad de que la compañía extranjera se estableciera en el país anfitrión, por la vía transfronteriza, ya sea mediante la movilidad del productor o del consumidor (Armendáriz y Mijangos, 1995: 268). 
La liberalización de la banca en México sería de forma gradual, buscando evitar que el sector bancario fuese controlado por capital extranjero. En el TLCAN la banca nacional quedaba protegida, es decir se aplicaban ciertas barreras o salvaguardas para evitar determinados efectos adversos provenientes de la presencia de bancos extranjeros en nuestra país, tales como: la amenaza de que el sistema de pago mexicano fuese controlado por extranjeros y los efectos que la presencia de bancos extranjeros pudieran tener sobre la habilidad de México para conducir con efectividad sus políticas monetaria y cambiaria.

Sobre la protección al sector bancario de México, Patricia Armendáriz y Margarita Mijangos, explican:

[...] para los bancos mexicanos existe un periodo de transición que durará hasta el año 2000; durante un lapso, México obtuvo una salvaguarda importante para el sector nacional, ya que el capital neto individual de los bancos extranjeros no podrá rebasar un tamaño equivalente a $1.5 \%$ del capital neto. El 1.5\% logrado significa que los bancos extranjeros establecidos en México no rebasen individualmente durante el periodo de transición un tamaño equivalente al que ahora tienen en promedio las cinco instituciones más pequeñas del país. (Armendáriz y Mijangos, 1995: 276)

México fue flexible al permitir la libre entrada al país de instituciones especialistas en el financiamiento de diversos segmentos de consumidores (tarjetas de crédito, prestamos hipotecarios etc.) como non bank banks e intermediarios de objeto limitado con un alto grado de rentabilidad en Estados Unidos, que representaron un alto grado de competencia para la banca comercial.

A continuación presentó algunos de los acuerdos establecidos en materia financiera, para el caso de México, con base a un estudio realizado por Eugenia Correa (Correa, 1995: 304306):

- La entrada de las empresas financieras de los países del norte a México podrá hacerse mediante subsidiarias que sólo podrán alcanzar hasta cierto porcentaje del mercado, durante un periodo de transición, o bien, asociándose con los intermediarios ya 
establecidos, bajo las condiciones que la ley mexicana establece, hasta $30 \%$ del capital contable en el caso de la banca comercial y casas de bolsa.

- Se establece el compromiso de otorgamiento de "trato nacional", sin que esto implique la modificación de la ley de los países vecinos que restringen la participación nacional de distintos intermediarios, ni implicaba cambios a la legislación mexicana con respecto a la participación accionaria de extranjeros.

- El establecimiento por medio de subsidiarias en banca, casa de bolsa y seguros queda restringido por una cuota de participación en el capital total según el tipo de institución financiera que se incrementa anualmente, durante el periodo de transición definido por seis años o hasta el primero de enero del año 2000.

- Existe una prerrogativa que permite a México, por una única vez durante los cuatro años siguientes al periodo de transición, congelar la participación de filiales extranjeras en la banca si rebasa el $25 \%$ y en las casa de bolsa el $30 \%$ del mercado.

- Se permite restringir la participación de un inversionista individual extranjero que exceda el cuatro por ciento. Se establece el compromiso de no aplicar restricciones a la prestación de servicios financieros transfronterizos a residentes de cualquiera de las tres naciones. En este punto opera una reserva de México que permite tales transacciones solo cuando estén denominadas en una moneda distinta al peso.

- Respecto a la "salvaguarda del sistema de pagos" mexicano se acordó que bajo el mecanismo de "consulta", México podrá solicitar consultas con los otros dos países cuando la suma de los capitales autorizados para las filiales extranjeras rebase $25 \%$ del capital de las instituciones de crédito y considere que se generen efectos adversos en el sistema de pagos o bien que exista la amenaza de que este quede bajo control de extranjeros.

- Cualquiera de las tres partes podrá mantener o adoptar medidas razonables por motivos prudenciales; para proteger a inversionistas, intermediarios o la estabilidad en el sistema financiero. Las entidades públicas encargadas de la conducción de la política financiera y cambiaria podrán adoptar medidas no discriminatorias y de aplicación general con dichos objetivos.

- Lo anterior no anula que los países se obligan a permitir todas las transferencias internacionales, libremente y sin demora, en divisas al tipo de cambio del mercado. 
- En el capitulo 21 relativo a excepciones, se explica que un país puede adoptar o mantener medidas que restrinjan pagos o transferencias cuando enfrente dificultades serias en su balanza de pagos. Pero dichas restricciones son solo temporales y el país tendrá obligadamente, que negociar con el Fondo Monetario Internacional (FMI) para eliminar los orígenes del desajuste

- Un país puede adoptar medidas prudenciales, con base en acuerdos o convenios, otorgando un reconocimiento unilateral.

Con la entrada en vigor del TLCAN, el sistema financiero mexicano se encontraría en la cúspide de la desregulación y liberalización iniciada a finales de la década de los setenta. Las cuales han marcado un camino lleno de privatización, fusiones y adquisiciones dejando un sistema bancario propiedad de extranjeros, este hecho analizará más adelante.

La desregulación financiera y la firma del TLCAN cambiaron la forma de operación, posicionamiento y participación de los bancos en el mercado, lo que condujo a una expansión del crédito bancario mucho más rápida. Dicha expansión se vio frenada por la crisis de 1994-1995, evidenciando un severa fragilidad, llevando a la quiebra el sistema bancario y financiero de México.

\subsection{Sobre la crisis financiera y bancaria de 1994-1995}

La crisis financiera de México tuvo sus raíces en el intenso proceso de endeudamiento interno y externo de los agentes económicos que siguió a la reforma financiera de 1989, cuyos principales elementos fueron la apertura de la cuenta de capitales y la privatización de los bancos comerciales, como ya se ha mencionado. Influyó también la reestructuración del sistema productivo provocada por la apertura comercial, la cual llevó a un desequilibrio creciente de la balanza de cuenta corriente. El déficit de esta cuenta se multiplicó por diez, al aumentar de 2,922 md en 1988 a 29,419 md en 1994. (Guillén, 2007: 230)

Ante la liberalización y desregulación financiera, así como la eliminación del encaje legal

(depósitos obligatorios de los bancos comerciales ante el banco central). Los bancos privatizados se encontraron con una abundancia de recursos que debían ser colocados. El 
financiamiento al sector privado y a las personas físicas de altos ingresos creció de forma exponencial; alentado por las bajas tasas de interés, aumentando los créditos de la banca comercial en más del cien por ciento.

El endeudamiento externo creció de la mano del financiamiento interno. Debido a diversos factores, entre los que sobresalieron la abundancia de recursos en el mercado internacional de capitales; la existencia de tasas reales de interés más bajas en los mercados externos; y la confianza de los inversionistas sobre la presunta firmeza de la política cambiaria del gobierno de Salinas de Gortari, las empresas se endeudaron crecientemente en el exterior. La banca comercial también incrementó sus pasivos en el exterior, con el objeto de ampliar sus operaciones activas y de aprovechar las diferencias entre el costo de fondeo en el mercado externo y el interno.

El crecimiento desmedido del crédito interno y externo privado, en el marco de altas tasas reales de interés internas, provocó una situación de sobreendeudamiento y falta de liquidez de las empresas e individuos, y un crecimiento acelerado de las carteras vencidas de los bancos y otros intermediarios financieros. El sobreendeudamiento se agravó con el proceso de desaceleración de la economía mexicana iniciada a finales de 1992. La supervisión estatal del sector financiero se debilitó enormemente con la privatización bancaria. La regulación prudencial fue prácticamente abandonada., las operaciones irregulares y fraudulentas de los bancos fueron numerosas; estos más preocupados en colocar aceleradamente activos, en captar recursos del público y en iniciar negocios de dudosa viabilidad, para no quedarse fuera del arribo al primer mundo prometido por el presidente Salinas, no evaluaron los créditos con rigor bancario.

La situación en 1994 era insostenible. El nivel de endeudamiento de las empresas y bancos era muy alto. El peso se encontraba sobrevaluado en más de un 30\%, debido al anclaje del peso respecto al dólar. En Estados Unidos, la FED resolvió modificar la política monetaria y comenzó a elevar las tasas de interés, lo que automáticamente repercutió en el nivel de las tasas internas y en el servicio de la deuda externa de México. Por otro lado, la situación política se modificó radicalmente a partir de la insurrección zapatista indígena en Chiapas 
y, unos meses después, con el asesinato del candidato oficial del PRI, Luis Donaldo Colosio y de otro destacado político del partido en el gobierno (Ruiz Massieu).

Debido a la desconfianza generada por los hechos antes mencionados, la fuga de capitales no se hizo esperar y las reservas monetarias empezaron su cuenta descendente. Según datos del FMI, previo a la devaluación del peso se fugaron capitales de nacionales por 4,600 md. (Guillén, 2007: 232)

En diciembre de 1994, el nuevo presidente Ernesto Zedillo, ante la continuación de la fuga de capitales y la imparable merma de las reservas monetarias del país se decidió a devaluar la moneda. La devaluación detonó la crisis financiera y aceleró las tendencias recesivas de la economía mexicana, latentes desde finales de 1992.

A pesar de la devaluación, la fuga de capitales continuó imparable. Los capitales externos exigieron la redención de sus Tesobonos ${ }^{1}$ en dólares, no obstante que sus rendimientos estaban legalmente nominados en pesos. El "efecto tequila" y el contagio en otros mercados latinoamericanos y en Estados Unidos se dio de manera inmediata.

La crisis mexicana fue la primera crisis de la globalización financiera con efectos sistemáticos. Al margen de la existencia de factores internos, la causa principal de la crisis fue la entrada masiva e indiscriminada de capitales externos de cartera. Estos capitales provocaron con su ingreso, la sobrevaluación del peso y alentaron el sobreendeudamiento de los agentes económicos; después con su retiro masivo, una vez que se comprobó que la estabilidad cambiaria no era sostenible, provocaron la crisis cambiaria y bancaria.

"El año de 1995 trajo consigo una caída del PIB del 7\% y una tasa de inflación cercana al $50 \%$. El Desempleo alcanzó al 25\% de la población económicamente activa, mientras los salarios sufrieron una perdida de poder adquisitivo del orden del 55\%, y dos millones y

\footnotetext{
${ }^{1}$ Títulos indexados al dólar que se conviertieron en la inversión favorita tanto de los especuladores nacionales como internacionales; el valor nominal de estos títulos vendidos a descuento se entrega en pesos indexados al dólar, pero la libre convertibilidad del peso aseguraba a los onversionistas la conversión a dólares y la libre remisión de su capital y ganancias al extranjero. (Cabello, 199 : 277)
} 
medio de personas más franquearon el umbral de la pobreza extrema." (Chesnais, 2001: 322)

En el primer trimestre de 1995 en México se inició una grave recesión económica. Con el fin de estabilizar los mercados financiero y cambiario, salvar a los inversionistas institucionales y evitar que condujera a una crisis sistémica internacional generalizada, el gobierno mexicano negoció con la administración estadounidense un paquete de rescate por 51, 637 millones de dólares provenientes del gobierno estadounidense, del FMI, del Banco Mundial y de otras fuentes.

Para ese mismo año se estimó la magnitud del sobreendeudamiento mediante las siguientes cifras (Correa, 2002: 79):

1. La deuda pública externa ascendió en diciembre de 1995 a 117000 millones de dólares incluyendo las deudas con el FMI y la deuda externa de la banca de desarrollo.

2. La deuda externa del sector privado no financiero ascendió a 30000 millones de dólares

3. La deuda externa de los bancos mexicanos se estimó en 30000 millones de dólares.

4. Las autoridades financieras estimaron que en 1996 las amortizaciones de la deuda externa, sin incluir la deuda externa de la banca local eran de 28.7 millones dólares. A lo que deben agregarse los intereses devengados que alcanzan a ser por lo menos de 14000 millones de dólares.

Además aplicó un programa de ajuste ortodoxo severo, caracterizado por una política monetaria y fiscal fuertemente restrictiva.

Para salvar a los bancos, a los banqueros y a los grandes empresarios involucrados, se ejecutó un amplio programa de rescate (Fobaproa, después IPAB) financiado con recursos públicos. El costo del rescate bancario representó el 20\% del PIB. La banca comercial fue prácticamente rematada al capital extranjero, quien en la actualidad controla el $90 \%$ del sistema de pagos mexicanos. 


\subsection{Fobaproa e IPAB, el rescate bancario.}

Ante posibles crisis financieras que propiciaran la insolvencia de los bancos por el incumplimiento de los deudores con la banca y el retiro masivo de depósitos, en 1990 se creó el Fondo Bancario de Protección al Ahorro (Fobaproa) que serviría para asumir las carteras vencidas y capitalizar a las instituciones financieras.

"Al estallar la crisis financiera los bancos privados se encontraban con una cartera vencida de 40000 millones de pesos. Los niveles de sobreendeudamiento eran exorbitantes, considerando los intereses devengados durante 1996 por la deuda externa (5.5\%), los intereses devengados por la cartera bancaria total (17\%) y los intereses de la deuda pública interna (2.3\%), el monto de los intereses representaba 24.8\% del PIB." (Correa, 2002: 80)

Estos números eran muestra clara de un endeudamiento insostenible para la economía mexicana, el sobreendeudamiento fue enfrentado con una deflación de los activos en moneda nacional, de ingresos de los asalariados y de los ingresos públicos; significó una contracción del crédito bancario y el traslado de activos improductivos al Fobaproa.

El problema del sobreendeudamiento ha sido trasladado al presupuesto público, sin poder los deudores nacionales recuperar su capacidad de pago, los grandes créditos otorgados sin poder recuperarse, la contracción monetaria y crediticia ha sacrificado a los sectores de la actividad económica con un mayor vínculo al mercado interno.

En marzo de 1998, la administración del Presidente Zedillo envió al Legislativo un paquete de cuatro iniciativas para crear un marco legal que pretendía reducir las posibilidades de una nueva crisis bancaria, así como para crear mecanismos más eficientes de supervisión a las actividades crediticias y facilitar la capitalización de los bancos.

Las iniciativas fueron:

1. Decreto que abroga la Ley Orgánica del Banco Nacional de Comercio Exterior, Sociedad Nacional de Crédito, Institución de Banca de Desarrollo.

2. Decreto que reforma la Ley del Banco de México

3. Decreto por el que se adiciona la Ley del Banco de México; se expide la Ley de la Comisión Nacional Bancaria y de Valores, y se reforman las leyes para Regular las 
Agrupaciones Financieras, de Instituciones de Crédito, General de Organizaciones y Actividades Auxiliares de Crédito, del Mercado de Valores, y de Sociedades de Inversión

4. Decreto por el que se expiden la Ley Federal del Fondo de Garantía de Depósitos y la Ley de la Comisión de Recuperación de Bienes, y se reforman, adicionan y derogan diversas disposiciones de las leyes del Banco de México, de Instituciones de Crédito, del Mercado de Valores, para Regular las Agrupaciones Financieras y General de Deuda Pública.

Con el objetivo de exigir mayor disciplina en la administración del sistema bancario, el Ejecutivo propuso la creación del Fondo de Garantía de Depósito (Fogade), instancia que protegería el dinero de pequeños y medianos ahorradores e involucraría al Poder Legislativo en la tarea de supervisar los bancos.

Asimismo, propuso la instauración de la Comisión para la Recuperación de Bienes, cuya función consistiría en recuperar, administrar y enajenar bienes y derechos que el Fobaproa y el Fondo de Apoyo al Mercado de Valores (Fameval) adquirieran como resultado de la crisis.

La propuesta que causó mayor controversia y que orilló al Congreso a ordenar una auditoría al Fobaproa fue la de convertir en deuda pública los pasivos de dichos fondos que sirvieron para asistir a los bancos, cuyo monto ascendió a 552,000 millones de dólares.

La promulgación de la Ley de Protección al Ahorro Bancario o LPAB en diciembre de 1998 por el Congreso mexicano, dispuso la creación del Instituto para la Protección al Ahorro Bancario (IPAB), como un intento de lanzar un "nuevo sistema de protección al ahorro bancario"

Esta ley ordenó al IPAB la asunción de las operaciones instrumentadas por el Fobaproa de conformidad con el articulado transitorio de la LPAB. La LPAB señala que el Instituto no es causahabiente universal del Fobaproa. Esto significa que el IPAB nace con una personalidad jurídica propia y con mandatos y facultades establecidas en la ley que lo rige. 
Un hecho innegable es que el traspaso del rescate de los bancos a las finanzas públicas así como su depuración para su venta a bancos extranjeros, transfiere a los contribuyentes las pérdidas provocadas por políticas públicas equivocadas, prácticas privadas ilegales y fraudulentas y por las políticas impulsadas por del FMI. Que condujeron a la pérdida sobre el control nacional del sistema de pagos, de la moneda y el crédito y a la preeminencia de la banca extranjera en el mercado nacional.

Para Morera, el rescate mediante las políticas gubernamentales tuvieron dos propósitos fundamentales (Morera, 2002: 117):

a) pagar a los acreedores internacionales $y$

b) garantizar la solvencia de los grupos de capital financiero sobreendeudados, pese al proceso obligado de estatización (intervención), asociación y fusión (compra de activos por parte de inversionistas extranjeros y nacionales).

Mas adelante advierte; " uno de los propósitos fundamentales del rescate financiero fue proteger y adecuar la estructura oligopólica creada, beneficiaria y gestora de los grandes flujos de capital obtenidos como resultado de las reformas". (Morera, 2002)

A pesar de que en México es mínima la proporción de habitantes que son ahorradores o deudores de los bancos, son ellos los que ven reflejado el costo del rescate en la disminución de sus ingresos y en el recorte de presupuesto en sectores tan importantes como el de la salud y educación.

Al respecto Correa señala;

El traspaso de los costos del rescate de los bancos a las finanzas públicas y su saneamiento para la venta y control por bancos extranjeros, transfiere a los contribuyentes las pérdidas generadas por políticas públicas equivocadas, prácticas privadas fraudulentas e ilegales [...] Todo ello esta conduciendo a la pérdida del control nacional sobre el sistema de pagos la moneda y el crédito y al predominio de la banca extranjera en el mercado nacional (Correa, 2002: 82). 


\subsection{La extranjerización de la banca}

El proceso de apertura y desregulación que ha vivido el sistema bancario del país, se encuentra en un momento en el que la banca se ha transformado de tal forma que en la actualidad ésta se halla en propiedad de extranjeros.

Con las modificaciones realizadas en 1998 en la legislación mexicana y la creación del IPAB, a los inversionistas extranjeros les sería permitido poseer y controlar las acciones con derecho a voto de los bancos comerciales, independientemente del tamaño del banco.

Anteriormente a las modificaciones a la legislación, no era permitido a los inversionistas extranjeros sostener más del $20 \%$ de las acciones devengadas de bancos que mantuvieran una posición por encima del 6\% de capital contable del sistema bancario en su conjunto, por lo que la adquisición de los tres mayores bancos estaba prohibida hasta ese momento.

Aunque en México se siga manteniendo en circulación la moneda local, más de la tercera parte de los activos y operaciones del sistema se denomina en dólares, si se adiciona el cambio tecnológico y la innovación financiera que han modificado el tipo de operaciones bancarias así como la organización bancaria, que han permitido rebasar limites geográficos, para la expansión y traslados de activos, así como para realizar transacciones financieras y control administrativo.

A consecuencia de lo anterior, en un corto tiempo en México se vivió un proceso de rápidas adquisiciones, los tres bancos más grandes del país fueron vendidos en menos de un año. Así pues, para inicios del año 2000 Grupo Financiero Serfin fue adquirido por Banco Santander Central Hispano (BSCH). Ese mismo año Banco Bilbao Viscaya (BBVA) adquirió el segundo grupo financiero más grande de México Bancomer, consolidándose el grupo BBVA-Bancomer como el mayor banco mexicano con una participación del 25\% (Maya, 2004: 234). Esta adquisición fue la primera operación extranjera en la que no existió asistencia financiera del gobierno, esto es de un banco no intervenido. En septiembre del 2001 Citybank concretó la compra del grupo financiero Banacci Accival (Banamex). 
En la gran parte de las transacciones de los bancos adquiridos se reportaron importantes reducciones en los costos, reflejado en la reducción de personal y aumento de sus ingresos, así como en las modificaciones de sus estrategias en operaciones.

Distintos han sido los argumentos para apoyar dicha extranjerización, como que: la tenencia extranjera puede contribuir a la estabilidad y desarrollo de los sistemas bancarios locales, mayor competencia permitiría una mayor eficiencia, disponibilidad de servicios y menores costos de financiamiento y mejoramiento del sistema bancario local, así como una mayor disponibilidad de fondos. Todos estos argumentos apoyan la liberalización y apertura de la economía (Maya, 2004: 237)

Pero la realidad en la experiencia mexicana, demuestra que la expansión del control extranjero del sistema bancario no ha representado un beneficio para el país, en ninguno de los aspectos antes mencionados y la extranjerización ha reducido el numero de bancos en el sistema financiero nacional concentrándose en un reducido grupo de bancos extranjeros, que han fortalecido a la oligarquía financiera del país.

Un hecho a destacar es que en América Latina, la participación de la banca extranjera no se presentó como un hecho aislado, ya que en otros países también se dio un incremento de dicha participación en su sector bancario durante la década de los noventa y se fue profundizando para los primeros años del nuevo milenio. Como se observa en el cuadro 5 . En el caso de México la participación de la banca extranjera en el mercado de acuerdo al porcentaje de activos, pasó de ser de $1 \%$ en 1994 a un $90 \%$ en el 2001, esta información muestra que el proceso de extranjerización de la banca se hizo más fuerte después de la crisis financiera de 1994-1995 y que encontraría niveles más elevados a finales de esa década (ver cuadro 5).

En el mismo cuadro se puede observar que Argentina y Chile que durante este periodo siguieron la misma política neoliberal, también tuvieron un incremento en la participación de la banca extranjera ya que para el 2001 sería de $61 \%$ y $62 \%$ respectivamente. 
Cuadro 5. Participación de la Banca Extranjera en los activos de la Banca Latinoamericana, 1994-2001 (en porcentajes)

\begin{tabular}{lcccc}
\hline & $\mathbf{1 9 9 4}$ & $\mathbf{1 9 9 9}$ & $\mathbf{2 0 0 0}$ & $\mathbf{2 0 0 1}$ \\
\hline Argentina & 18 & 49 & 49 & 61 \\
Brasil & 8 & 17 & 23 & 49 \\
Chile & 16 & 54 & 54 & 62 \\
México & 1 & 19 & 24 & 90 \\
Venezuela & 1 & 42 & 42 & 59 \\
\hline \hline
\end{tabular}

Fuente: CEPAL, 2003

En este sentido Vidal argumenta,

El incremento de la participación del capital extranjero en la segunda parte de los años noventa implica cambios importantes en la estrategia de reforma de los sistemas financieros y en el tipo de participación de los capitales privados que se busca promover en varios países. Estos cambios son el resultado de la política económica ejecutada en la primera parte de los años noventa (Vidal, 2006:53).

La concentración que devino de la extranjerización de la banca, también se observa en la reducción del número de bancos no sólo en México, sino también en otros países latinoamericanos (véase cuadro 6). Así, en 1994 en el país existían 36 bancos y para el año 2000 éste número se redujo a 23 y de éstos la participación en el mercado se concentraba en los 3 mayores bancos. Esta participación era en 1994 de 48.3\% y se incrementó para el año 2000 al $56.3 \%$. Esto ocurre como consecuencia de las fusiones y adquisiciones que se siguieron presentando durante los años posteriores a la crisis mexicana y hasta los primeros años de la década del 2000.

Como puede observarse en el cuadro 6, para los demás países de Latinoamérica la concentración bancaria no es tan distinta al caso mexicano para estos años. Aunque podría cambiar el escenario para los años posteriores ya que todos los países dentro del cuadro (a excepción de México), cambiaron su estrategia política y económica, pero sobre esto no se 
profundizará en el presente trabajo, ya que no es el objeto de estudio, solo se menciona para contextualizar el escenario internacional.

Cuadro 6. América Latina: Indicadores de concentración en el sector bancario 1994-2000 (Participación en los depósitos totales)

\begin{tabular}{|c|c|c|c|c|c|c|}
\hline & \multicolumn{3}{|c|}{1994} & \multicolumn{3}{|c|}{2000} \\
\hline & $\begin{array}{c}\text { Número } \\
\text { de } \\
\text { Bancos }\end{array}$ & $\begin{array}{l}\text { Participa } \\
\text { ción de } \\
\text { los } 3 \\
\text { mayores } \\
(\%)\end{array}$ & $\begin{array}{l}\text { Participa } \\
\text { ción de } \\
\text { los } 10 \\
\text { mayores } \\
(\%)\end{array}$ & $\begin{array}{c}\text { Número } \\
\text { de } \\
\text { Bancos }\end{array}$ & $\begin{array}{c}\text { Participa } \\
\text { ción de } \\
\text { los } 3 \\
\text { mayores } \\
(\%)\end{array}$ & $\begin{array}{c}\text { Participa } \\
\text { ción de } \\
\text { los } 10 \\
\text { mayores } \\
(\%)\end{array}$ \\
\hline Argentina & 206 & 39.1 & 73.1 & 113 & 39.8 & 80.7 \\
\hline Brasil & 245 & 49.9 & 78.8 & 193 & 55.2 & 85.6 \\
\hline Chile & 37 & 39.5 & 79.1 & 29 & 39.5 & 82.0 \\
\hline México & 36 & 48.3 & 80.8 & 23 & 56.3 & 94.5 \\
\hline Venezuela & 43 & 43.9 & 78.6 & 42 & 46.7 & 75.7 \\
\hline
\end{tabular}

Fuente: Elaboración propia con información de CEPAL, 2003 información en www.eclac.org, consultado en abril del 2012.

Cuadro 7. Participación de los mayores bancos en el mercado mexicano a diciembre de 2000

(millones de pesos y porcentajes)

\begin{tabular}{lcc}
\hline \multirow{2}{*}{\multicolumn{1}{c}{ Bancos }} & \multicolumn{2}{c}{ Activo } \\
\cline { 2 - 3 } \multicolumn{1}{c}{ Total } & Monto & \% \\
\hline BBVA Bancomer & $384,478,321.39$ & 100 \\
Banamex & $301,859.50$ & 20.42 \\
Serfin & $125,463.80$ & 8.49 \\
Bital & $117,777.70$ & 7.97 \\
Santander & $99,684.50$ & 6.74 \\
Mercantil del Norte & $99,183.60$ & 6.71 \\
Citibank & $88,471.30$ & 5.98 \\
Scotiabank Inverlat & $61,507.90$ & 4.16 \\
\hline \hline Fuente: Elaboración propia con información de la Comisión Nacional \\
Bancaria y de Valores, Boletín Estadístico de Banca Múltiple, diciembre \\
de 2000
\end{tabular}


Gráfica 1. Participación de los 5 mayores bancos en el mercado mexicano a diciembre de 2000 (porcentajes)

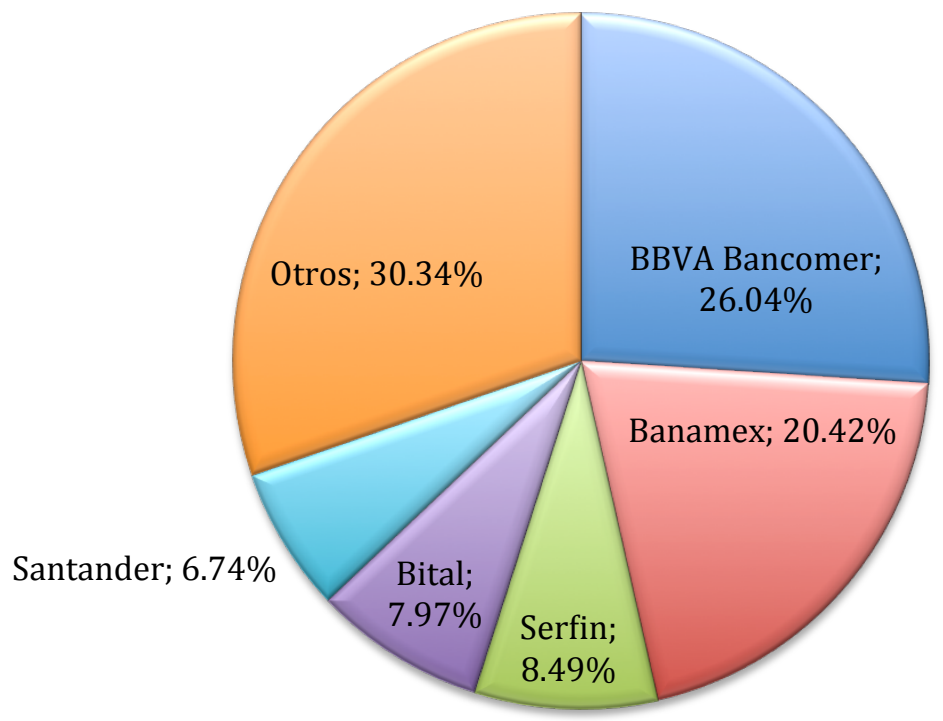

Fuente: Elaboración propia con información de la Comisión Nacional Bancaria y de Valores, Boletín Estadístico de Banca Múltiple, diciembre de 2000.

La presencia de banca extranjera en el país, ha implicado un control del sistema bancario prácticamente monopólico, en donde los precios y en general la estructura del mercado se ven determinados por los participantes extranjeros.

En el cuadro 7 y en la gráfica 1 observamos que para diciembre de 2000 la participación bancaria en el mercado estaba encabezada por dos grandes bancos, BBVA-Bancomer y Banamex que sumados concentraban el $46.46 \%$ del mercado. El resto lo componen bancos con una participación mucho menor ya que ni siquiera alcanzan el 10\%, tal es el caso de Serfin, Bital, Santander etc.

La fragilidad del sistema bancario es la fragilidad misma de la economía en general y si bien el proceso de extranjerización se encuentra en un punto muy avanzado, serían importantes modificaciones que permitieran contrarrestar o detener este proceso. Si bien para los capitalistas resulta un buen negocio, para el país ha representado una menor 
competitividad de los pocos bancos mexicanos, el olvido casi total de la banca de desarrollo y la creación de una nueva cultura de consumo entre la sociedad en el cual el endeudamiento a base de créditos bancarios, parecería que es una moda heredada de los países del primer mundo.

Pero la realidad es que en México lejos de detenerse el proceso de extranjerización, éste siguió su curso en los primero años del nuevo siglo y la concentración de la banca extranjera se ha incrementado como se analiza en el siguiente capítulo. 


\section{CAPÍTULO 4. LA BANCA COMERCIAL EXTRANJERIZADA}

El presente capítulo se enfoca en el análisis de la participación extranjera en la banca comercial durante la última década. El objetivo principal de éste apartado es estudiar como se incrementó dicha participación durante los primeros años del nuevo siglo, lo que dio como resultado una mayor concentración del negocio bancario en unos cuantos conglomerados principalmente extranjeros, consolidándose una oligarquía financiera con características particulares.

\subsection{Un análisis de la banca extranjerizada}

Después de más de una década de haberse iniciado en el país el proceso de desregulación y liberalización del Sistema Bancario, éste se encuentra a inicios del nuevo mileno en posesión de extranjeros casi en su totalidad. Como se desarrolló en el capitulo anterior, la extranjerización del sector bancario fue un proceso ejecutado en fases, hasta que se conformó la banca comercial como actualmente la conocemos.

Ésta es una banca que solo ha resultado rentable para los grandas grupos financieros, quienes a través de compras y fusiones se apropiaron de los bancos más importantes del país. Un caso que ejemplifica claramente lo redituable de dichas compras, es el de Banamex, adquirido por Citigroup;

El Citigroup, [...], después de haber incursionado en la región durante un siglo -bajo la denominación de Citibank - concentrado en la banca corporativa y en la banca privada - atención de clientes de altos ingresos - dio en 2001 un gran salto hacia la banca de consumo, al adquirir el Banco Nacional de México (BANAMEX) en 12500 millones de dólares. Esta política forma parte de la estrategia global del Citigroup, que en los últimos años se ha estado reestructurando y ha hecho especial hincapié en el área global de consumo (Consumer Group) de los mercados emergentes. (CEPAL, 2002: 136)

La adquisición del Banamex permitió al Citigroup aumentar en forma extraordinaria sus ingresos en América Latina, así como el número de cuentas de clientes.

En el caso de México los ingresos de Citigroup (ver cuadro 8), pasaron de 603 millones de 
dólares en 2000 a 2,117 millones en 2001, su número de clientes tuvo un aumento considerable al pasar de 1.7 millones a 16.1 millones de clientes.

De ese modo, en 2001 los ingresos aumentaron 59\% con respecto al año 2000, al pasar de 2 200 millones de dólares a 3500 millones. Al mismo tiempo, el número total de cuentas de clientes se expandió de 7 a 23 millones en el conjunto de América Latina, gracias a la incorporación de 16 millones de cuentas del BANAMEX.

Cuadro 8. Importancia de la incorporación de Banamex a Citigroup

\begin{tabular}{|c|c|c|c|c|c|c|}
\hline & \multicolumn{2}{|c|}{$\begin{array}{l}\text { Total de ingresos netos } \\
\text { (millones de dólares) }\end{array}$} & \multicolumn{2}{|c|}{$\begin{array}{l}\text { Número de clientes } \\
\text { (millones) }\end{array}$} & \multicolumn{2}{|c|}{$\begin{array}{c}\text { Promedio de préstamos } \\
\text { (miles de millones de } \\
\text { dólares) }\end{array}$} \\
\hline & $\begin{array}{l}\text { Resto América } \\
\text { Latina }\end{array}$ & México & $\begin{array}{l}\text { Resto América } \\
\text { Latina }\end{array}$ & México & $\begin{array}{c}\text { Resto América } \\
\text { Latina }\end{array}$ & México \\
\hline 1999 & 1638 & 531 & 7.6 & 1.4 & 7.7 & 3.9 \\
\hline 2000 & 1656 & 603 & 7.2 & 1.7 & 7.2 & 3.7 \\
\hline 2001 & 1380 & 2117 & 7.1 & 16.1 & 7.1 & 11.3 \\
\hline
\end{tabular}

Fuente: CEPAL, La Inversión extranjera en América Latina y el Caribe, 2002.

Y como el caso de Citigroup, se podría decir que para otros grandes grupos financieros presentes en el mercado mexicano como BBVA y Santander, el haber adquirido bancos mexicanos les ha resultado un gran negocio.

Ya que han visto incrementadas sus utilidades dado el incremento de sus activos en el sector bancario del país.

Como se observa en el cuadro 9 el banco que ha tenido una mayor participación en el mercado bancario ha sido BBVA-Bancomer cuyos activos han tenido un incremento constante al pasar de 416,172.9 millones de pesos en 2002 a 1,165,977.2 millones en 2010, la diferencia entre esos años fue de 749,804.2 millones de pesos es decir tuvieron un incremento de $180 \%$ de sus activos en el territorio nacional en un periodo de 8 años. 
Cuadro 9. Participación en el mercado de los mayores bancos en México por activos (millones de pesos)

\begin{tabular}{lcccccc}
\hline & 2002 & 2004 & 2006 & 2008 & 2009 & 2010 \\
\hline BBVA Bancomer & $416,172.9$ & $549,804.7$ & $600,836.3$ & $1,179,244.1$ & $1,119,186.8$ & $1,165,977.2$ \\
Santander & $109,764.3$ & $174,876.4$ & $402,075.2$ & $704,925.5$ & $586,831.2$ & $680,478.4$ \\
Serfin* & $108,109.3$ & $136,192.3$ & & & & \\
Banamex & $426,627.1$ & $469,620.3$ & $538,881.1$ & $961,180.7$ & $1,091,159.2$ & $1,112,367.5$ \\
HSBC & $159,374.4$ & $202,832.3$ & $284,045.4$ & $468,083.3$ & $393,799.0$ & $429,120.3$ \\
Scotiabank Inverlat & $83,010.0$ & $104,691.3$ & $127,150.0$ & $174,433.1$ & $180,997.9$ & $200,475.9$ \\
Mercantil del Norte & $193,493.5$ & $168,371.7$ & $209,031.9$ & $552,509.0$ & $536,116.3$ & $555,510.8$ \\
Inbursa & $58,400.5$ & $87,068.7$ & $80,800.3$ & $204,646.3$ & $203,070.9$ & $249,200.1$ \\
\hline \hline
\end{tabular}

* En 2005 se fusionó con Santander

Datos a fin de periodo

Fuente: Elaboración propia con información de la Comisión Nacional Bancaria y de Valores, Boletín Estadístico, varios años

El caso de Santander, otro banco español, cuyos activos han tenido un aumento considerable al pasar de 109,764.3 millones de pesos a 680,478.4 millones después de adquirir Serfin. La diferencia fue de 570,714.1 millones de pesos, éste incremento fue de mas de $519 \%$ de 2002 a 2010.

En el mismo cuadro se pueden observar caso por caso, el comportamiento de los activos de los principales grandes bancos operando en el sector bancario del país y este comportamiento nos indica un aumento de la participación de los bancos extranjeros. Que se han aliado con los capitalista nacionales que han aceptado esta relación a cambio de tener una mayor participación en la matriz.

La financiarización de la economía mexicana ha permitido mantener la participación de la banca extranjera en el mercado, provocando la concentración de las ganancias en un pequeño grupo de capitalistas que encabezan la oligarquía financiera que se ha consolidado gracias a dicha financiarización y desregulación del sector financiero. 
Pero si bien a los beneficiados de este proceso los tenemos ubicados, lo mismo ocurre en el caso contrario, es decir la economía mexicana en su conjunto que no se ha favorecido en este proceso. La desregulación y extranjerización de la banca ha hecho que ésta haya dejado rezagado un hecho fundamental de su operar: El crédito a la producción, la banca ha diversificado sus operaciones con la única máxima de obtener mayores ganancias y esto solo lo ha conseguido mediante operaciones de mucho mayor riesgo como en el mercado de derivados, compra de deuda pública, financiamiento al consumo (tarjetas de crédito) y que claramente no se encuentran en el financiamiento a la producción. Esto ha reforzado el bajo crecimiento de la economía al no representar un sector de la economía que cumpla con la que debería ser una de sus principales funciones la de financiar la producción.

En este sentido Roberto Soto advierte;

[...] Esto ha provocado que el proceso de financiamiento productivo disminuya, lo que dificulta así el funcionamiento empresarial que permita la reactivación del mercado interno así como la generación de un crecimiento y desarrollo de la economía en su conjunto [...] (Soto, 2010: 126)

Este cambio en el tipo de financiamiento ha afectado el crédito otorgado por la banca comercial hacia sectores productivos del país, por ejemplo: el crédito otorgado al sector agropecuario paso de $3.76 \%$ en el año 2000 a $1.55 \%$ del total de los créditos otorgados por la banca comercial en 2010. Hubo una disminución del crédito de alrededor de $5.72 \%$ que representa una cifra importante. El sector industrial si bien muestra una disminución en el crédito, éste ha despuntado en los últimos años y para 2010 tuvo un crédito de $20.95 \%$ (ver cuadro 10).

El crédito al consumo ha tendido a aumentar ya que de representar $4.64 \%$ en el 2000 alcanzó un máximo de $28.14 \%$ en 2007 , mientras que el crédito otorgado a la vivienda ha venido disminuyendo durante la primera década de 2000 al pasar de $21.06 \%$ a $17.89 \%$. Esto nos indica como se ha modificado el negocio bancario, ya que el crédito que otorgan se concentra en el sector que les reditúa mayores ganancias debido a las mayores tasas de interés y los menores plazos, como lo es el crédito al consumo. 
Otro aspecto fundamental que se ha venido modificando con la apropiación de la banca por los grupos financieros encabezados por extranjeros, es el hecho de que el financiamiento que la banca comercial otorga al sector no bancario, se concentra esencialmente en el sector privado del país quedando muy por debajo el financiamiento al sector público.

Como se observa en el cuadro 11 el financiamiento al sector privado paso de 966,433,905 miles de pesos en el año 2000 a 1,921,851,037 miles de pesos al 2010, existe una diferencia en esos años de 955,417,132 miles de pesos.

Así, el financiamiento al sector privado representa el $68.46 \%$ del total del crédito otorgado por la banca comercial y el sector público (sumado el financiamiento a los estados y municipios) $27.79 \%$ del total al 2010 (véase gráfica 2).

Una de las causas de que esto ocurra, sugiere que los grandes grupos financieros concentran su financiamiento en el sector que le reditúa mayores ganancias. La banca vive de la deuda pública y no del financiamiento productivo.

Cuadro 10. Crédito otorgado por la Banca Comercial por actividad

\begin{tabular}{cccccc}
\multicolumn{7}{c}{} & \multicolumn{3}{c}{ (porcentaje) } \\
& $\begin{array}{c}\text { Sector agro., } \\
\text { silvícola y } \\
\text { pesquero }\end{array}$ & $\begin{array}{c}\text { Sector } \\
\text { industrial }\end{array}$ & $\begin{array}{c}\text { Sector servicios } \\
\text { y otras } \\
\text { actividades }\end{array}$ & $\begin{array}{c}\text { Crédito a la } \\
\text { vivienda }\end{array}$ & $\begin{array}{c}\text { Créditos al } \\
\text { consumo }\end{array}$ \\
\hline 2000 & 3.76 & 19.63 & 23.43 & 21.06 & 4.64 \\
2001 & 3.41 & 18.54 & 21.63 & 19.04 & 6.65 \\
2002 & 2.16 & 16.84 & 21.52 & 16.64 & 8.62 \\
2003 & 2.20 & 16.66 & 20.52 & 14.41 & 12.43 \\
2004 & 1.98 & 17.40 & 22.09 & 13.87 & 17.60 \\
2005 & 1.83 & 13.91 & 20.35 & 15.53 & 23.38 \\
2006 & 1.55 & 13.95 & 21.34 & 17.48 & 28.02 \\
2007 & 1.60 & 17.49 & 21.11 & 16.60 & 28.14 \\
2008 & 1.74 & 20.22 & 22.69 & 16.77 & 25.13 \\
2009 & 1.49 & 20.40 & 22.00 & 17.49 & 19.97 \\
2010 & 1.55 & 20.95 & 21.56 & 17.89 & 19.12 \\
\hline \hline
\end{tabular}

Fuente: Elaboración propia con información de Banco de México, estadísticas, financiamiento e información financiera de intermediarios financieros, en internet www.banxico.org, consultado en mayo de 2012. 
Algo que debe de ser considerado en este análisis es el hecho indiscutible de que la economía mexicana y el sector bancario en específico, se conducen bajo la financiarización existente a nivel internacional. Como se ha venido insistiendo éste nuevo régimen financiarizado, trajo consigo cambios e innovaciones financieras que tuvieron claras implicaciones en la modificación del tipo de financiamiento de la banca comercial en México.

Estos cambios que venían produciéndose en el mundo se aceleraron y profundizaron como resultado de la revolución tecnológica. En este contexto, dos tendencias en desarrollo adquirieron particular relevancia:

- La rápida e intensa integración de los mercados financieros. En el plano nacional se profundizaron los vínculos entre las distintas entidades a través de los mercados interbancarios, así como de los sistemas de pagos. En el ámbito internacional, la liberalización de los movimientos de capital en la mayoría de las economías del mundo y el rápido y extendido desarrollo de las tecnologías de la información y las comunicaciones se tradujeron en un alto grado de interconexión entre los distintos mercados financieros.

- El surgimiento y la proliferación de innovaciones financieras y de operadores con alta propensión al riesgo. Entre las primeras sobresalen los denominados productos estructurados ${ }^{2}$, mientras que en los segundos se destacan los fondos de inversión libre - también denominados instrumentos de inversión alternativa y fondos de alto riesgo, que comprometieron la estabilidad de los mercados por su naturaleza y modo de operar. (CEPAL, 2011: 152)

\footnotetext{
${ }^{2}$ Los productos estructurados, también conocidos como inversión de mercado relacionado, son activos financieros de renta fija ligados a instrumentos derivados, como un valor único, una canasta de valores, opciones, materias primas, emisión de deuda o divisas. En general, estos productos, que son el resultado de una permuta financiera subyacente, se transan de manera extrabursátil y bilateral, por lo que es difícil asignarles un precio. Entre los productos estructurados más comunes se destacan las obligaciones de deuda garantizada, los títulos garantizados.
} 
Cuadro 11. Financiamiento otorgado por la banca comercial al sector no bancario. (Saldos nominales, miles de pesos)

\begin{tabular}{ccccc}
\hline & $\begin{array}{c}\text { Financiamiento } \\
\text { total }\end{array}$ & $\begin{array}{c}\text { Financiamiento al } \\
\text { sector privado }\end{array}$ & $\begin{array}{c}\text { Financiamiento al } \\
\text { sector público }\end{array}$ & $\begin{array}{c}\text { Financiamiento a } \\
\text { estados y } \\
\text { municipios }\end{array}$ \\
\hline 2000 & $1,262,892,024$ & $966,433,905$ & $49,087,479$ & $48,082,191$ \\
2001 & $1,239,055,393$ & $924,447,474$ & $72,339,730$ & $46,937,988$ \\
2002 & $1,266,882,529$ & $924,137,305$ & $56,241,325$ & $49,509,577$ \\
2003 & $1,309,355,307$ & $886,240,159$ & $103,268,561$ & $64,372,236$ \\
2004 & $1,391,239,489$ & $944,124,527$ & $206,281,769$ & $71,578,339$ \\
2005 & $1,412,144,497$ & $989,778,245$ & $176,998,346$ & $79,224,258$ \\
2006 & $1,589,587,299$ & $1,255,092,364$ & $136,487,904$ & $68,374,227$ \\
2007 & $1,922,720,957$ & $1,572,981,727$ & $163,931,538$ & $69,665,305$ \\
2008 & $2,143,744,836$ & $1,794,596,163$ & $196,349,179$ & $95,147,168$ \\
2009 & $2,438,643,806$ & $1,794,379,526$ & $434,437,411$ & $173,993,224$ \\
2010 & $2,807,461,402$ & $1,921,851,037$ & $561,087,243$ & $218,997,808$ \\
\hline \hline
\end{tabular}

Fuente: Elaboración propia con información de Banco de México, estadísticas, financiamiento e información financiera de intermediarios financieros, en internet www.banxico.org, consultado en mayo de 2012.

Gráfica 2. Financiamiento de la banca comercial al sector no bancario (Porcentajes)

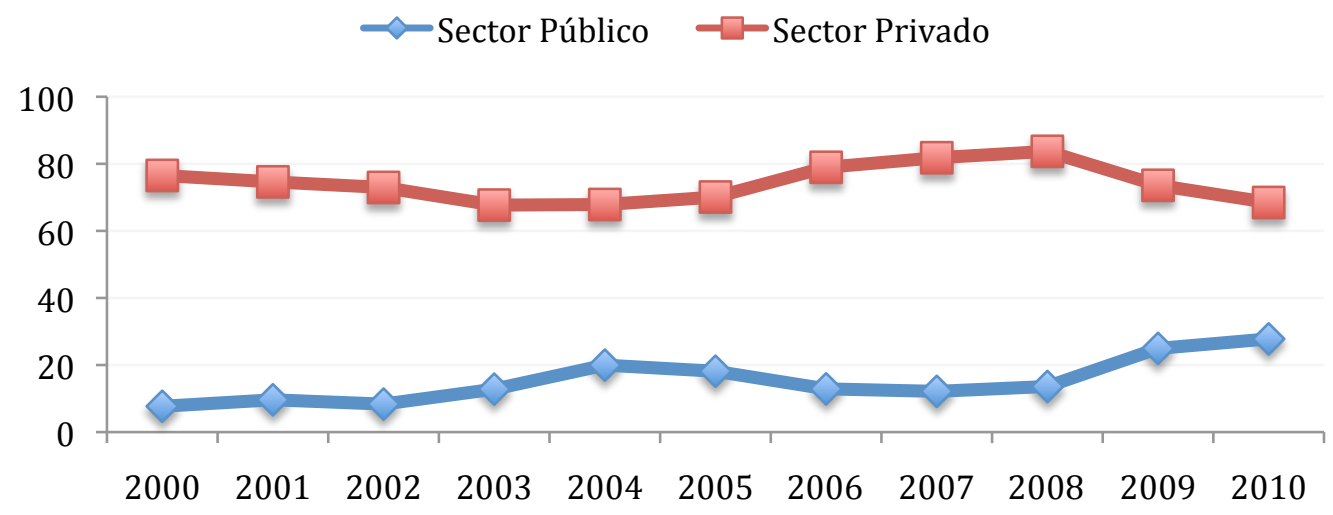

Fuente: Elaboración propia con información de Banco de México, estadísticas, financiamiento e información financiera de intermediarios financieros, en internet www.banxico.org, consultado en mayo de 2012.

\subsection{Banca comercial en México y la crisis global de 2007}

Los cambios en el modo de operar del sistema financiero mundial, con menor aversión al riesgo, al inicio del nuevo siglo trajeron consigo una serie de situaciones que perturbaron a la economía mundial, comenzando con la crisis de Argentina (2001) y la recesión de Estados Unidos (2001-2002). 
Pero tal vez la crisis más desastrosa por sus consecuencias a nivel internacional, como: quiebras de grandes bancos, desplomes de las bolsas en todo el mundo y 700,000 millones de dólares gastados por el gobierno estadounidense en el rescate bancario (por mencionar algunas), es la crisis global que comenzó a finales del 2007 y que hasta la fecha sigue causando estragos en la economía mundial.

Ésta crisis ha dejado muy claro que el papel de los gobiernos a nivel mundial se ha venido modificando a favor de los sistemas financieros. Ejemplo de esto, es que en la crisis actual y en la Crisis Mexicana de 1994-1995, los gobiernos fungieron como rescatistas de los grandes bancos, invirtiendo miles de dólares para evitar que muchos de ellos quebrarán.

Otro hecho importante y que ha caracterizado a esta crisis es el papel de los inversionistas institucionales y las calificadoras de riesgo, cuya participación en el sistema financiero se ha venido incrementado y fortaleciendo de manera significativa y han jugado un papel fundamental en el estallido de la crisis actual. Al ser quienes fomentaron la especulación con títulos que resultaron ser riesgosos, inflando la burbuja especulativa que estalló a finales del 2007.

Como se analizó en el capítulo 1, esta crisis que se inició en los Estados Unidos no es una nueva crisis para México, sino que viene a profundizar problemas que no han sido resueltos desde el fin del modo de acumulación por medio de la sustitución de importaciones (MSI) a finales de 1970, dejando un país con un alto nivel de endeudamiento, un incremento sustantivo del empleo informal, la extranjerización de la industria productiva con la entrada de las empresas transnacionales (ET), una fuerte concentración del ingreso y una banca comercial propiedad de unos cuantos capitales extranjeros principalmente de Estados Unidos y España. Todos estos hechos que resultan una realidad para el país, son en sí mismos un objeto de investigación y no se profundizará en ellos, pero es importante mencionarlos como un hecho irrefutable.

La crisis iniciada en el sector inmobiliario de los Estados Unidos se esparció rápidamente por las principales economías, se dieron las caídas en las bolsas de valores más importantes así como las quiebras de instituciones bancarias relevantes. 
En México esta crisis se había calificado como un "catarrito" por el entonces Secretario de Hacienda Agustín Carstens, pero dados los hechos se tuvo que modificar ese diagnostico. Aunque las autoridades mexicanas no han dejado de aseverar que esta crisis, es una nueva crisis para el país y que viene del exterior, ignorando los problemas estructurales no resueltos de décadas atrás.

La respuesta oficial al primer golpe de la crisis financiera global [...] fue que cualquier turbulencia financiera del vecino del norte no afectaría a México [...] Pero fue apenas en marzo de 2008, cuando colapsó el banco de inversión Bear Stearns, que la postura oficial mexicana cambió a un pronóstico de "catarrito" para el país. Cuando Lehman Brothers entró en banca rota [...] las autoridades nacionales asumieron la posición de que México estaba sufriendo de una crisis importada (Marshall, 2011: 219)

Si bien es cierto que en esta investigación se basa en la hipótesis de un crisis de larga duración en México, crisis actual que en palabras de Correa, Marshall y Vidal;

[...] representa los límites del modelo económico neoliberal, que se basa en políticas de crecimiento impulsado por las exportaciones, por una apertura comercial y financiera, financiamiento externo y una reducción del papel del Estado en las actividades económicas, todo bajo condiciones de dominación financiera. Una parte fundamental de este modelo económico, que ha sido aplicado en diferentes grados en la mayoría de los países en desarrollo, es la sustitución sistemática de los bancos de propiedad pública, por las de propiedad extranjera, una tendencia que ha llevado a un cambio en las estructuras de endeudamiento interno y externo en los países en desarrollo $^{3}$. (Correa, Marshall, Vidal, 2010: 5)

Así pues independientemente del debate de si esta crisis es importada o no, una de las consecuencias de la extranjerización de la banca en México, es que los bancos con filiales en el extranjero tienen la posibilidad de transmitirles la crisis.

${ }^{3}$ La traducción es de la autora 
Según el FMI, si hay una crisis financiera en el país de origen de un banco internacional, sucursales o filiales extranjeras podrían verse afectadas. Si un banco internacional tiene entidades extranjeras de tamaño suficiente, o si todos los bancos internacionales entran en crisis en sus países de origen, una crisis financiera podría surgir en un país que de otro modo no habrían experimentado. (FMI, 2007:14) (Citado por Correa, Marshall, Vidal, 2010: 11)

Mas adelante los mismos autores advierten;

La pérdida de la banca nacional en México ha llevado al desarrollo de la crisis de dos formas generales: la primera tiene una forma similar a la advertida por el FMI, mientras que la transmisión de la otra surge de las deudas externas de las empresas mexicanas. En ambos casos, México, ofrece importante advertencia para otros países de la región. Con más del 80\% del sistema bancario en manos extranjeras (medido por activos) el sistema bancario del país está más internacionalizado que el de cualquier otra gran economía. Durante los años de dominación de los bancos en propiedad extranjera, todas las empresas mexicanas han sufrido un notable racionamiento del crédito. (Correa, Marshall, Vidal, 2010: 12).

Otra consecuencia de que el sector bancario del país se encuentre en propiedad extranjera, es que se ha limitado el crédito interno que éste proporciona, sobre éste punto Eugenia Correa argumenta:

“[...] con un sistema financiero dominado por filiales de bancos extranjeros completan el cuadro de un modelo con muy reducido e incluso descendente crédito doméstico en moneda local al sector privado no financiero. Un modelo de servicios financieros articulado para la deslocalización del ahorro doméstico y, como filiales de bancos globales, ampliamente generador de rentabilidad para sus matrices a través de la especulación con productos derivados.” (Correa, 2010: 101).

De tal forma es como la crisis financiera global se ha venido abriendo paso en México. El argumento de que la extranjerización de la banca en México garantizaría un crédito 
creciente y de bajo costo para la inversión y para las empresas locales, se demostraría falso con el paso del tiempo y con la llegada de esta crisis.

También se argumentaba que eran bancos tan grandes y bien capitalizados que sus filiales también lo serían, de manera que no se presentaría una nueva crisis bancaria. Fue hasta 2007, en medio de la crisis financiera global, cuando el FMI advirtió que ello no podría ser tan cierto y que una crisis financiera en el país de la matriz del banco, podría perjudicar a las filiales en otros países. (Correa, 2010: 98)

La crisis global sin duda ha hecho estragos en la economía mexicana, y ha profundizado las dificultades a las que se viene enfrentando desde hace varias décadas.

A continuación se presenta a manera de resumen, el camino que ha seguido la crisis en México desde los noventa hasta finales de la primera década del nuevo siglo, basados en los argumentos de Eugenia Correa (Correa, 2010: 95-97):

1. Como consecuencia del impulso de las política exportadoras a partir del TLCAN, las empresas más importantes se internacionalizaron, pero al mismo tiempo son altamente demandantes de fondos externos, pues mantienen importantes pasivos en dólares.

2. La liberalización comercial del TLCAN destruyó parte importante de las capacidades internas de producción, entre ellas del agro y la industria alimentaria. Con la crisis, la especulación en futuros de materias primas ha encarecido parte importante de las importaciones de alimentos, que demandan crecientes fondos también en divisas y encarece los alimentos básicos.

3. La distribución del ingreso se deteriora con cada nueva crisis económico-financieras en la historia reciente de México.

4. La mayor parte del sistema bancario está operado por filiales de los bancos globales que, con la crisis actual, se han vuelto insolventes e incluso están quebrados. Lo que coloca al sistema financiero mexicano en proveedor de liquidez y elevados rendimientos para la matriz. Además, una parte de la rentabilidad de este sistema procede del soporte gubernamental, mientras que el financiamiento para el mercado interno declina.

5. Se adoptaron y siguen vigentes las leyes de autonomía del banco central (1994) y de 
responsabilidad fiscal (equilibrio, 1998), de manera que el gasto público en esta crisis ha sido procíclico, aumentando la presión tributaria a la caída de los ingresos y de la actividad económica;

6. La deuda pública tanto interna como externa, se ha convertido en la fuente de ganancias más seguras para el sector financiero y en una pesada carga para las finanzas públicas. La deuda pública interna ha aumentado en estos tres años de la crisis global en casi un 70\%, superando los 3 billones de pesos. El endeudamiento neto de estos 3 años (nuevas disposiciones de deuda menos amortizaciones) es de 360 mil millones de pesos (mmdp) promedio anual. Estimamos que el pago de intereses de esta deuda equivale a casi de la mitad del endeudamiento neto. Debe agregarse que al menos un $15 \%$ de los valores gubernamentales están en manos de no residentes.

7. La deuda pública externa aumentó [... en casi 40 mmdd, o más de un 70\%.

8. Los mayores empresarios locales han sufrido una rápida metamorfosis, de manera que pocos han sobrevivido a la apertura y liberalización. Otros se han internacionalizado y otros más se han asociado con grupos extranjeros. En medio de la crisis global se ha redoblado la presión por la remisión de utilidades y dividendos hacia los grupos con matrices en los países desarrollados. De manera que también estos flujos tienen un comportamiento procíclico.

9. El deterioro institucional y político de más de 20 años del modelo neoliberal (desregulador y liberalizador) con la crisis global se hace más evidente como incapacidad de gobierno, ilegitimidad y fragmentación del poder político. Las instituciones fundamentales del Estado, en materia de aplicación de la justicia están ampliamente deterioradas, los medios de comunicación altamente concentrados van perdido credibilidad, mientras que el país se militariza.

10. La reciente incertidumbre, la enorme vulnerabilidad y el deterioro económicos han fragilizado la economía y la sociedad en el país, ahora con instituciones debilitadas y con enormes carencias de confianza y legitimidad.

La fuerza con la que la crisis actual ha sacudido a la economía de México, ha sido mayor en comparación a otras economías latinoamericanas que no se encuentran tan internacionalizadas como la nuestra. Como se analizó líneas arriba dicha 
internacionalización en el sector bancario provocó que las matrices en el extranjero buscarán aliviar sus problemas, recurriendo a sus filiales en el extranjero.

En México existe una importante concentración de la cartera de crédito en posesión de bancos extranjeros. Como se observa en el cuadro 12 son BBVA-Bancomer y Banamex los que tienen una mayor cartera de crédito que en 2010 representa el 26.98 y 15.64 como porcentaje de la cartera de crédito total y sumada es $42.62 \%$.

Otro caso significativo es el de uno de los bancos españoles con mayor presencia en América Latina, Santander, que después de adquirir Serfin tuvo un incremento importante en su cartera de crédito en el país ya que antes de dicha adquisición en 2001 era de 6.49 y paso a $15.08 \%$ en 2006.

Cuadro 12. Cartera de crédito de los principales bancos en México como proporción de la cartera total (Porcentaje del total)

\begin{tabular}{lccccccc}
\hline & 2001 & 2004 & 2006 & 2007 & 2008 & 2009 & 2010 \\
\hline BBVA Bancomer & 27.44 & 27.33 & 26.82 & 27.3 & 27.53 & 26.39 & 26.98 \\
Banamex & 22.49 & 20.15 & 16.21 & 16.1 & 14.61 & 17.80 & 15.64 \\
Serfin* & 7.99 & 6.61 & & & & & \\
HSBC & 7.02 & 10.17 & 11.69 & 11.8 & 9.15 & 8.13 & 7.93 \\
Santander & 6.49 & 7.10 & 15.08 & 12.9 & 12.15 & 10.47 & 10.66 \\
Mercantil del Norte & 8.89 & 9.22 & 9.41 & 10.6 & 11.79 & 11.33 & 11.54 \\
Scotiabank Inverlat & 5.98 & 6.57 & 6.28 & 5.4 & 5.25 & 5.08 & 8.40 \\
Inbursa & 3.24 & 5.12 & 4.69 & 5.0 & 7.59 & 8.22 & 8.40 \\
\hline \hline & * En 2005 se fusiono con Santander \\
Datos a fin de periodo & & & & & & \\
Fuente: Elaboración propia con información de la Comisión Nacional Bancaria y de Valores, \\
Boletín Estadístico, varios años.
\end{tabular}

La participación de la banca extranjera en el país (medida por sus activos), se ha venido incrementando a lo largo de las dos últimas décadas, este comportamiento ha tenido variaciones significativas ya que antes de la crisis global los activos de la banca extranjera llegaron a representar el 78\% del total, pero esto cambio después de que estallará la crisis y para 2010 paso a ser del $66.98 \%$ (Gráfica 3). Lo cual refleja la fragilidad de tener un sistema bancario tan extranjerizado, ya que sin duda las filiales se verán en algún momento afectadas por la crisis. 
La banca comercial en México sigue concentrándose principalmente en siete bancos (medido por sus activos) de los cuales cinco se encuentran en posesión de extranjeros y de esos, dos (BBVA-Bancomer y Banamex) concentran $42.52 \%$ de los activos totales convirtiéndoles en los bancos más importantes del país (Ver gráfica 4).

Gráfica 3. Participación extranjera en el sector bancario de México

$\square$ Activos

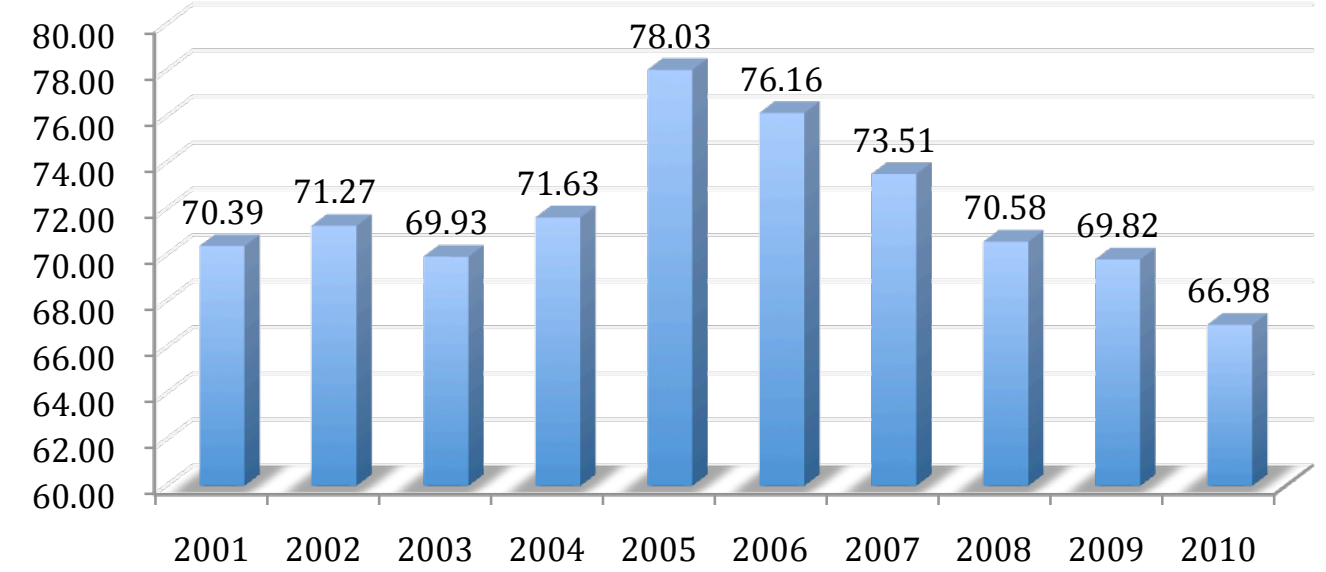

Fuente: Elaboración propia con información de Comisión Nacional Bancaria y de Valores, Boletín Estadístico, varios años.

Para 2010 año en que la crisis global no ha finalizado, el sector bancario del país sigue concentrándose en un numero reducido de bancos propiedad de extranjeros, lo que no ha permitido a la economía mexicana librarse de los estragos de la misma ni tampoco permite asegurar que los bancos mexicanos son bancos sólidos, ni que se encuentren fuertes ante la crisis, cuando son totalmente dependientes de las decisiones tomadas en sus matrices extranjeras.

La crisis global iniciada en Estados Unidos, actualmente ha afectado a muchos otros países Europeos que están tomando decisiones cruciales para sus economías. México al ser uno de los países Latinoamericanos más ligados a Estados Unidos, no ha salido librado. Como se trató de analizar en estos últimos capítulos la financiarización de la economía mexicana, la desregulación, liberalización y posterior extranjerización del sector financiero, han transformado el negocio de la banca comercial, pues dejó de tener como función esencial el 
financiamiento productivo pasando a los negocios con mayores riesgos pero también con mayores ganancias, tal como lo dicta el mercado mundial. Tendencia que se produce en el largo plazo.

Gráfica 4. Participación en el Mercado de México de los mayores bancos (2010)

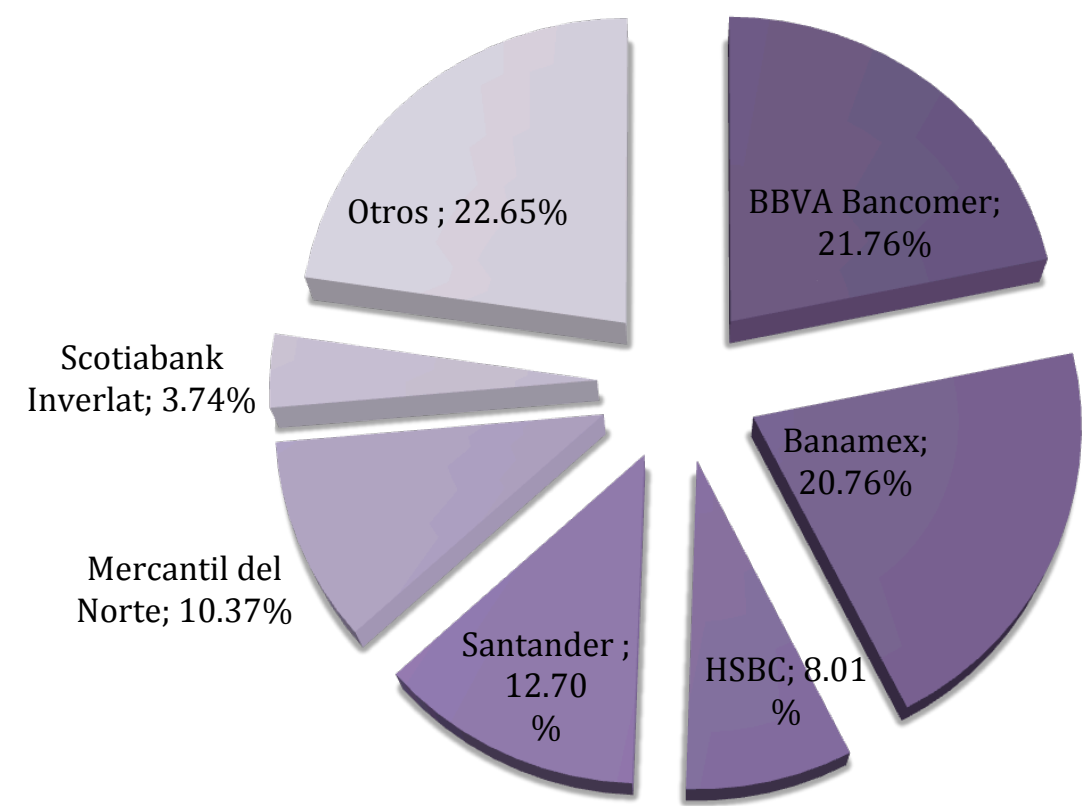

Fuente: Elaboración propia con información de Comisión Nacional Bancaria y de valores, Boletín Estadístico diciembre de 2010.

Para el sector bancario del país es difícil proporcionar un escenario en el cual, los bancos vuelvan a ser nacionales y cumplan con su función de financiar la producción así como promover el crecimiento económico del país. Dejar de ser una fuente tan importante de ganancia de un reducido grupo de capitalistas tanto nacionales como extranjeros que encabezan la oligarquía financiera y que esas ganancias se fuguen hacia los países donde se encuentra la matriz lo que implica que los bancos son redituables para otros países más que para México. 


\section{CONSIDERACIONES FINALES}

La situación económica en México ha tenido momentos de estancamiento y decrecimiento económico desde el fin del Modo de Sustitución de Importaciones (MSI) en la segunda mitad de los años setenta. Han pasado más de tres décadas en las cuales el país no ha podido alcanzar tasas de crecimiento que permitan superar problemas estructurales tales como, la precariedad salarial, el desempleo, la concentración del ingreso y la disminución de la pobreza.

Al margen de esta situación se dieron hechos que modificaron el negocio bancario, con la aprobación de leyes que convirtieron a la banca especializada en banca universal, incentivando la formación de conglomerados bancarios que con el paso de los años se han venido consolidando.

Entre los cambios que se han dado en la banca comercial, uno de los más importantes es la modificación del tipo de financiamiento, ya que hasta antes de la década de los ochenta del siglo pasado, éste se dirigía a la producción y fue durante estos años que se empezó a direccionar hacia otros negocios de alto riesgo pero que permitían la obtención de mayores ganancias.

Un hecho clave acontecido durante la década de 1980 fue la financiarización de la economía mexicana, como resultado de la bursatilización o titularización de la deuda. Esto después de que estalló la crisis de la deuda en 1982. La inclusión de México al mundo dominado por las finanzas, no fue solo una de las consecuencias del grave problema de la deuda sino también se incrementó la dependencia de le economía mexicana a las organizaciones mundiales como el FMI y el Banco Mundial y por supuesto a Estados Unidos.

Dicha dependencia queda clara dado que México renegocia la deuda con esos organismos y son éstos mismos quienes desde su gestación, han impulsado incansablemente la ejecución en el territorio mexicano de las reformas estructurales fieles promotoras del libre mercado y la desregulación económica. Fue en 1989 con el gobierno de Salinas de Gortari, que se 
establecería el nuevo orden mundial conocido como; modelo neoliberal y con el sus políticas desreguladoras que más que promover el crecimiento y desarrollo económico han implicado el enriquecimiento de un grupo minoritario de la sociedad.

En lo que respecta al sector bancario la entrada en vigor del nuevo orden y la reprivatización de la banca, no significaría otra cosa que la concentración de la banca comercial en unos cuantos grupos financieros principalmente extranjeros.

Con la firma del TLCAN se reforzó la desregulación financiera en el país, lo que permitió a los grupos españoles y estadounidenses apropiarse de la banca comercial en México.

Entre los resultados de esta investigación destacan los siguientes:

Los datos obtenidos en esta investigación muestran que, desde la década de los noventa los conglomerados extranjeros tienen una participación en los activos en el mercado mexicano de entre el 60 y 70\%. Como resultado de las fusiones y adquisiciones que se llevaron a cabo durante este periodo y que se prolongaron hasta iniciado el nuevo siglo. Además también nos muestran que son los grupos españoles BBVA-Bancomer y Santander y Citigroup de Estados Unidos quienes encabezan la lista

De lo anterior se puede decir que la extranjerización de la banca comercial en México es un hecho irrefutable, lo que ha permitido la conformación de una oligarquía financiera no nacional, encabezada por los conglomerados extranjeros. Esto no es un hecho aislado ya que podríamos considerar una tendencia de la financiarización mundial, a la centralización del negocio bancario en contados grandes grupos capitalistas.

La concentración de la participación en el mercado, ha implicado un cambio en el destino de los beneficios que ha dejado de ser totalmente nacional, ya que las ganancias obtenidas en el negocio bancario salen del país hacia sus matrices extranjeras, lo que a su vez es una consecuencia para la economía del país ya que esas ganancias no se invierten en la producción y por tanto no hay una aportación significativa por parte del negocio bancario al crecimiento económico de México. 
Otro de los resultados es que al integrarse México a este mundo dominado por las finanzas, la banca comercial cambió por completo su papel como fuente de financiamiento a la producción, ya que la financiarización como se definió en el segundo capítulo, prioriza y expande las actividades financieras en busca de la obtención de mayores ganancias sin importar la procedencia.

Es por eso que el tipo de financiamiento se ha diversificado tanto en las últimas décadas y se ha orientado hacia negocios de mayor riesgo pero que sin duda generan grandes ganancias, como el mercado de derivados y de futuros por ejemplo. Todo esto a favor de la gran oligarquía financiera, no solo la que se ha conformado en el país apropiándose de la banca comercial, sino a nivel mundial.

La desregulación financiera en el mundo ha alcanzado niveles inconmensurables y en mi opinión catastróficos, ya que desde 2007 la economía mundial se encuentra inmersa en una de las mayores crisis financieras que se haya tenido en la historia. Lo que se presentó como una crisis del sector inmobiliario en Estados Unidos, se manifestó de un momento a otro a las Bolsas de Valores mundiales dañando severamente el sistema financiero internacional.

En México las consecuencias de la actual crisis se presentaron irremediablemente, esto por la fuerte relación que existe con Estados Unidos y no podía esperarse lo contrario a pesar de que en su momento algunos funcionarios públicos opinaran diferente.

Para el sector bancario podríamos decir que las dificultades aún no han alcanzado el punto en el cual se tornen desastrosas, ya que al día de hoy los bancos con matrices extranjeras no han tomado decisiones que requieran recurrir a sus filiales en México. Eso pondría en serios problemas a un sector bancario desprotegido y frágil como lo es en éste país.

En la actualidad podemos observar algunos países europeos viviendo crisis que años atrás pocos imaginarían posible, entre ellos España. Dada la situación por la que hoy atraviesa la economía española podría tener repercusiones en la economía de México, con esto me refiero al hecho de que son los conglomerados españoles los dueños de los mayores bancos en el país. 
Lo anterior lo menciono porque es un hecho clave la relación que existe de la banca comercial en México con los grupos financieros foráneos, esto podría devenir en una profundización de los problemas estructurales que ya existen en la economía mexicana, ocasionando un deterioro grave al crecimiento económico del país.

En mi opinión la liberalización y desregulación financieras han ocasionado daños irreversibles a la economía del país y han dejado a la banca comercial supeditada a las decisiones que toman las grandes élites financieras extranjeras.

Hablar de una política que pueda contrarrestar los perjuicios que podrían provocar dichas decisiones en contra del bienestar económico del país es algo impensable, ya que en el contexto internacional, la dominación de las finanzas pareciera no tener limites. Y a pesar de la crisis mundial, la desregulación financiera se sigue impulsando por los grandes capitalistas financieros. Ya que es en la esfera financiera donde encuentran el espacio ideal para la generación de ganancias millonarias, siendo éstas su mayor objetivo. 


\section{BIBLIOGRAFÍA}

- Aguilar, Alonso; Carmona, Fernando; Guillén, Arturo y Hernández, Ignacio (1989). La Nacionalización de la Banca la crisis y los monopolios. Editorial Nuestro tiempo, cuarta edición, México.

- Armendáriz, Patricia y Mijangos, Margarita (1995). " Retos de la liberalización en el Tratado de Libre Comercio: el caso de los servicios bancarios ", en Girón, Alicia, Ortiz, Edgar y Correa, Eugenia (compiladores) Integración financiera y TLC retos y perspectivas. Editorial Siglo XXI, México.

- Banco de México (2012). Historia Sintética de la Banca en México, edición internet, www.banxico.org.mx, consultado en febrero de 2012.

- Cabello, Alejandra (1999). Globalización y liberalización financieras y la bolsa mexicana de valores. Del auge a la crisis. Plaza y Valdés Editores, México.

- Chesnais, François (2001). "Mundialización financiera y vulnerabilidad sistémica", en Chesnais, François (comp.). La mundialización financiera. Génesis, costo y desafios. Editorial Losada, S.A., Buenos Aires, Argentina.

- Correa, Eugenia, Ferreiro, Jesús y Gómez Ma. Del Carmen (2010). "Nueva estructura financiera y obstáculos del financiamiento al sector privado en México" en Girón, Alicia, Correa, Eugenia y Rodríguez, Patricia (coordinadoras) Banca Pública, crisis financiera y desarrollo. Universidad Nacional Autónoma de México, Instituto de Investigaciones Económicas, México.

- Correa (2010). "México, crisis económica y financiera" en Revista Ola Financiera, núm. 6, mayo-agosto, www.olafinanciera.unam.mx

- Correa, Eugenia, Marshall, Wesley y Vidal, Gregorio (2010). "Mexico's economic catastrophe: an innocent victim of the global crisis or a homegrown affair?" en International Economic Policy Institute, www.iepi.laurentian.ca

- Correa, Eugenia (2002). "FOBAPROA e IPAB: crisis y ocaso de los bancos mexicanos" en Correa, Eugenia y Girón, Alicia (compiladoras) Crisis y futuro de la banca en México. Grupo Editorial Miguel Ángel Porrúa. México

- Correa, Eugenia (1998). Crisis y desregulación financiera. Siglo XXI editores, Instituto de Investigaciones Económicas, México. 
- Correa, Eugenia (1995). "Servicios financieros y banca en el contexto del TLC”, en Girón, Alicia, Ortiz, Edgar y Correa, Eugenia (compiladores) Integración financiera y $T L C$ retos y perspectivas. Editorial Siglo XXI, México.

- Correa, Eugenia (1992). Los mercados financieros y la crisis en América Latina. Instituto de Investigaciones Económicas, UNAM, México.

- De Bernis, Gérard (2007). "De la urgencia de abandonar la deuda de las periferias" en Gregorio Vidal y Arturo Guillén (coordinadores), Repensar la teoría del desarrollo en un contexto de globalización. Homenaje a Celso Furtado, Consejo Latinoamericano de Ciencias Sociales, CLACSO, Buenos Aires, Argentina.

- De Bernis, Gerard (1988a). El capitalismo contemporáneo, Editorial Nuestro Tiempo, México.

- De Bernis, Gérard (1988b). “ Les contradictions des relations financières internationales dans la crise" en Economies et Sociétés. Séries $<<$ Théories de la Régulation $>>$. Crise et Crises Financières. I.S.M.E.A, Paris. Septembre.

- De Bernis, Gerard (1985). “ La crisis de las economías capitalistas avanzadas como crisis del modo de regulación de las economías capitalistas" en La fase actual del capitalismo, Editorial Nuestro Tiempo, UAM-I, UNAM, México.

- Epstein, Gerald (2001). "Financialization, rentier interests and central bank policy", paper, Department of Economics, University of Massachusetts, Amherts, MA, 7-8 december.

- Girón, Alicia (2010). "Financiarización, banca pública y banca social” en Girón, Alicia, Correa, Eugenia y Rodríguez Patricia (coordinadoras) Banca Pública, crisis financiera y desarrollo. UNAM, Instituto de Investigaciones Económica, México.

- Girón, Alicia y Levy, Noemí (2005). México: los bancos que perdimos. De la desregulación a la extranjerización del sistema financiero. Instituto de Investigaciones Económicas. Facultad de Economía. UNAM.

- Girón, Alicia (2002). "La Banca Mexicana en transición: ¿Crisis o restructuración?” en Correa, Eugenia y Girón, Alicia (compiladoras) Crisis y futuro de la banca en México, Miguel Ángel Porrúa, México. 
- Girón, Alicia (1995). “ La banca comercial en Canadá, Estados Unidos y México”, en Girón, Alicia, Ortiz, Edgar y Correa, Eugenia (compiladores) Integración financiera y $T L C$ retos y perspectivas. Editorial Siglo XXI, México.

- Green, Rosario (1981). "Bancarización de la deuda externa y condicionamiento de la capacidad decisoria del Estado nacional: el caso de México", en Estévez, Jaime y Lichtensztejn, Samuel (compiladores), Nueva Fase del capital financiero. Elementos teóricos y experiencias en América Latina, Editorial Nueva Imagen, México.

- Guillén, Arturo (2010). México hacia el siglo XXI. Crisis y modelo económico alternativo, Plaza y Valdez editores, segunda edición, México.

- Guillén, Arturo (2008). "Modelos de desarrollo y estrategias alternativas" en Correa, Eugenia, Déniz, José y Palazuelos, Antonio (coordinadores), América Latina y desarrollo económico. Editorial Akal, Madrid.

- Guillén, Arturo (2007). Mito y realidad de la globalización neoliberal. Grupo Editorial Miguel Ángel Porrúa.

- Guillén, Arturo (1989). "La renegociación y el desenvolvimiento reciente de la deuda externa de México", en Guillén, Arturo, Correa, Eugenia y Vidal, Gregorio, La deuda externa grillete de la nación, Editorial Nuestro Tiempo, México.

- Hilferding, Rudolf (1985). El Capital Financiero, editorial Tecnos, España.

- Marshall, Wesley (2011). México desbancado, causas y consecuencias de la pérdida de la banca nacional. Editorial Miguel Ángel Porrúa, México.

- Maya, Claudia (2004). "Banca Extranjera en México" en Correa, Eugenia y Girón, Alicia (coordinadoras) Economía Mexicana contemporánea. Editorial Miguel Ángel Porrúa, México.

- Morera, Carlos (2002). "La privatización de los servicios financieros y telefónicos en México en la década de los noventa", en Correa, Eugenia y Girón, Alicia (compiladoras), Crisis y futuro de la banca en México, Editorial Miguel Ángel Porrúa, México.

- Ortega, Rosa María y Villegas, Eduardo (1995). "Evolución reciente del Sistema Financiero Mexicano", en La industria y las finanzas en el México actual. Serie de Investigación 14, Universidad Autónoma Metropolita - Unidad Iztapalapa, México. 
- Rozo, Carlos (1987). "Desreglamentación, innovación y crisis financiera", en Revista Economía Teoría y Práctica, núm 10, primavera-verano, UAM, México.

- Soto, Roberto (2010). "Crisis del modelo bancario en América Latina" en Girón, Alicia, Rodríguez, Patricia y Déniz, José (coordinadores) Crisis Financiera. Nuevas manías. Viejos pánicos. Editorial Catarata, Madrid.

- Soto, Roberto (2009). "Finanzas públicas y Nueva banca en México", en Revista Ola financiera, núm. 2, enero-abril. www.olafinanciera.unam.mx

- Vidal, Gregorio (2011). "La economía internacional de endeudamiento: Dominación financiera y continuidad de la crisis" en Revista Ola financiera, num. 10, septiembrediciembre, www.olafinanciera.unam.mx

- Vidal, Gregorio (2008). "México y los acuerdos de libre comercio: Perspectivas después de más de dos décadas de reformas estructurales" en Casas, Ángel M. y Ochman, Marta, Integración, Desarrollo e Interregionalismo en las Relaciones entre la Unión Europea y América Latina, Miguel Ángel Porrúa Editor, México.

- Vidal, Gregorio (2006). "América Latina: banca, mercados de capital y determinación externa del crédito" en publicación: Reforma financiera en América Latina. CLACSO, Consejo Latinoamericano de Ciencias Sociales, Buenos Aires, Argentina. Acceso al texto completo: http://bibliotecavirtual.clacso.org.ar/ar/libros/edicion/correa/vidal.pdf

- Vidal, Gregorio (2002). Grandes empresas, economía y poder en México, Plaza y Valdés Editores, segunda edición, México.

- Vidal, Gregorio (1995). "La economía mexicana y los grupos financieros en la perspectiva del TLC", en Girón, Alicia, Ortiz, Edgar y Correa, Eugenia (compiladores), Integración financiera y TLC retos y perspectivas. Editorial Siglo XXI, México.

- Vidal, Gregorio (1989). "La deuda externa y el proceso de centralización y desvalorización del capital", en Guillén, Arturo, Correa, Eugenia y Vidal, Gregorio, $L a$ deuda externa grillete de la nación, Editorial Nuestro Tiempo, México.

- Vidal, Gregorio (1987). "Crisis y reestructuración del capital”, en Revista Economía Teoría y Práctica, núm 10, primavera-verano, UAM, México.

- Villegas, Eduardo y Ortega, Rosa Ma.(2002). Sistema Financiero de México, Editorial McGraw-Hill, México. 
- Wray, Randall. (2009). "Money manager capitalism and the global financial crisis". real-world economics review, issue no. 51, December, http://www.paecon.net/PAEReview/issue51/Wray51.pdf

\section{INFORMACIÓN ESTADÍSTICA}

- Banco de México (2012). Estadísticas en internet www.banxico.org.mx

- CEPAL (2011). La inversión extranjera en América Latina en internet www.eclac.org

- CEPAL (2003). La inversión extranjera en América Latina y el Caribe 2002 en internet www.eclac.org

- CEPAL (2002). La inversión extranjera en América Latina en internet www.eclac.org

- Comisión Nacional Bancaria y de Valores (varios años). Boletín Estadístico, en internet www.cnbv.gob.mx 
EL PAPEL DE LA BANCA COMERCIAL EN MEXICO, TRAS UN LARGO PROCESO DE

DESREGULACION (1980-2009)
En México, D.F., se presentaron a las 12:00 horas del día 18 del mes de octubre del año 2012 en la Unidad Iztapalapa de la Universidad Autónoma Metropolitana, los suscritos miembros del jurado:

\section{DRA. ALICIA ADELAIDA GIRON GONZALEZ \\ DR. WESLEY COLIN MARSHALL}

DR. JOSE GREGORIO VIDAL BONIFAZ
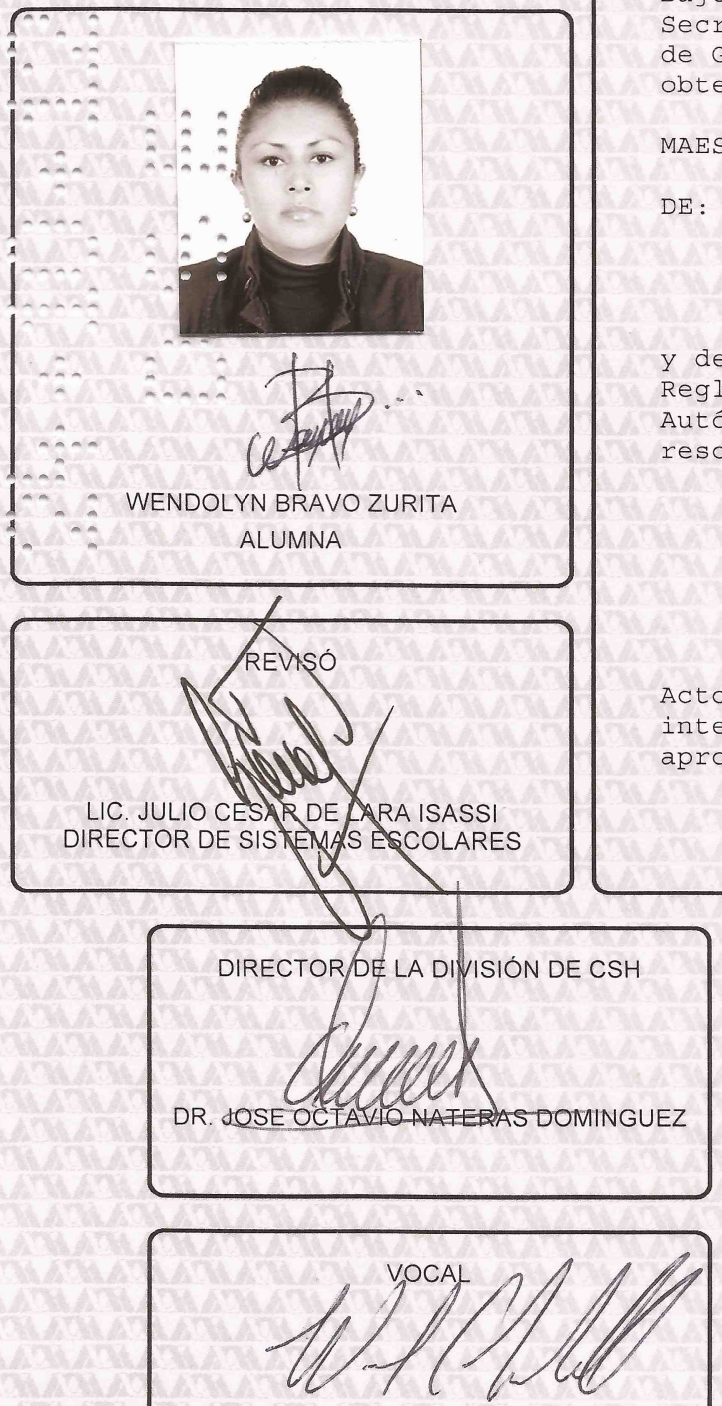

DR. WESLEY COLIN MARSHALL
Bajo la Presidencia de la primera y con carácter de Secretario el último, se reunieron para proceder al Examen de Grado cuya denominación aparece al margen, para la obtención del grado de:

MAESTRA EN ESTUDIOS SOCIALES (ECONOMIA SOCIAL)

DE : WENDOLYN BRAVO ZURITA

y de acuerdo con el artículo 78 fracción III de Reglamento de Estudios Superiores de la Universidad Autónoma Metropolitana, los miembros del jurado resolvieron:

\section{APROBOR.}

Acto continuo, la presidenta del jurado comunicó a la interesada el resultado de la evaluación y, en caso aprobatorio, le fue tomada la protesta.
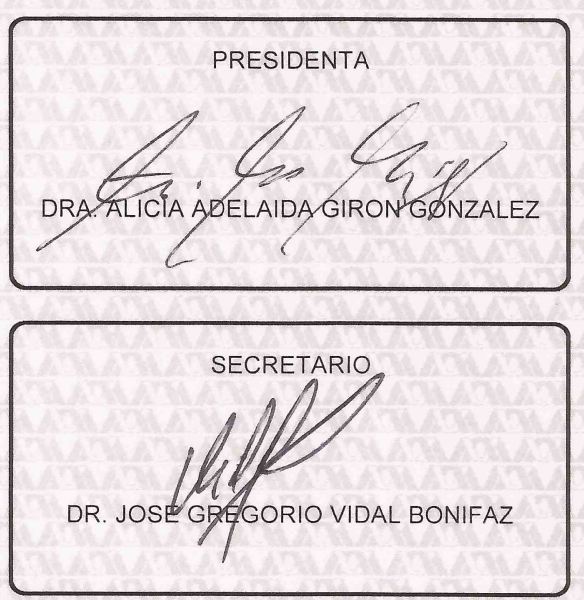